\title{
Tendências da linguagem científica contemporânea em expressividade digital: uma problematização
}

Sérgio Bairon

\section{Contemporary scientific language tendencies in digital expressiveness: an inquiry} possibilitou a estada na Alemanha durante o primeiro semestre de 2003. 
Resumo: Este artigo relaciona a pesquisa universitária e a linguagem da hipermídia. O novo desafio é produzir conhecimento com imagem, som e texto. Expressar o pensamento numa linguagem híbrida. O primeiro grande poder da hipermídia acadêmica está na hibridização de linguagens, processos sígnicos, códigos, mídias que ela aciona e, consequentemente, na mistura de sentidos receptores, na sensorialidade global, sinestesia reverberante que ela é capaz de reproduzir, na medida em que o interator imersivo interage com ela, cooperando na sua realização. Toda nova linguagem traz consigo novos modos de pensar, agir, sentir. Apresento algumas pesquisas universitárias (Brasil e Alemanha) que desenvolveram esta linguagem. O que tais procedimento revelam, acima de tudo, é que todo conhecimento tem algo de onírico. Imantado nessas camadas imersivas, o pensamento é jogo, coreografia de uma dança intelectual e sensível, na qual, o argumento estético-topológico se identifica com o conhecimento científico-filosófico.

Esta pesquisa foi o resultado de apoio recebido pelo DAAD Alemanha, durante o ano de 2003.

Palavras-chave: hipermídia, jogo, hibridização de linguagens, conhecimento científico-filosófico.

Abstract: This article relates the academic research and the language of the hypermedia. The new challenge is to produce knowledge with image, sound and text. To express the thought in a hybrid language. I present some academic research (Brazil and Germany) that developed this new language. The first significant power of academic hypermedia lies in the hybridization of languages, sign processes, codes, and media that it puts into action. The result is a mixture of channels of reception, a global sensoriality, a reverberating synaesthesia parallel with the immersion of the receiver or reader interaction while cooperating with its realization. Every new language brings with it new ways of thinking, acting, feeling. What such procedures reveal, above all, is that all knowledge has something oneiric. Magnetized in these layers of immersion, thought is play, choreography of an intellectual and sensitive dance in which, thanks to the multilinear web of hypermedia, the aesthetic-topological argument merges with the scientificphilosophic knowledge.

This research was the support result received by DAAD Germany, during the year of 2003.

Keywords: hypermedia, play, languages hybridization, scientific-philosophic knowledge. 
Desde o século XVIII, no Ocidente, desenvolvemos a metodologia da ciência como matéria obrigatória em praticamente todas as regionalidades científicas. ${ }^{1}$ Esta tradição elegeu a matriz verbal da escrita como a grande representação do pensamento analítico reflexivo. ${ }^{2}$ À essência institucional deste pensamento analítico (no meio acadêmico universitário a escrita moldou a fala), composto por um processo de fragmentação dos objetos de pesquisa, somaram-se inúmeras características de fundamentos filosófico-teóricos que, independente de suas variações e abordagens, determinaram a relação leitura/escrita como o único caminho possível à reflexão científica. ${ }^{3}$ Neste caminho de historicidade, houve inúmeros momentos que fizeram da divisão (institucional) entre arte e ciência, a expressividade da ruptura entre, de um lado, o predomínio da escrita metodológica na ciência e, de outro, a relevância das manifestações imagéticas e sonoras na arte. Apesar de inúmeros movimentos filosóficos terem defendido a idéia da paridade entre signos de características sonoras, imagéticas e verbais, que estaria presente em todo processo reflexivo, ${ }^{4}$ a verdade sempre esteve associada à colusão institucional de que somente a escrita, fruto da leitura de textos consagradamente científicos, poderia representar a condição máxima do juízo analítico. ${ }^{5}$ As divisões institucionais entre arte e ciência nos dias de hoje ainda guardam, sobretudo institucionalmente, esta tradição. ${ }^{6}$

É deste lugar que pretendo partir à proposição da seguinte problematização: terão as produções hipermidiáticas da década de 90 do século passado e dos primeiros anos deste século, desenvolvidas sobretudo nas universidades brasileiras e alemãs, a possibilidade de demonstrar novos desafios à expressividade do pensamento científico? Este artigo, portanto, pretende ser somente a colocação do problema. ${ }^{7}$ Noutro momento, intenciono demonstrar como, a partir das grandes relações entre filosofia, ciência e metodologia, esta tendência de esquecimento e solapamento dos signos de predominância imagética e sonora, foi sendo construída. ${ }^{8}$ Nesse início de século, temos possibilidades, quase ilimitadas, de desenvolvermos uma metodologia hipermídiática de pesquisa científica, que sirva tanto para processos de produção quanto de avaliação do conhecimento científico. Neste contexto, os maiores desafios estão localizados na lide resultante da relação entre os recursos hipermidiáticos à disposição e a proposta de renovação teórico-temática do trabalho científico de tradição verbal escrita. Estes desafios, até certo ponto interdependentes, têm uma dimensão institucional, outra dimensão de competências a serem desenvolvidas pelos próprios pesquisadores e uma outra, epistemológica.

Os desafios institucionais situam-se na transformação dos estágios burocráticos, existentes ainda hoje, como premissas para que um trabalho científico seja aceito. ${ }^{9}$ Os desafios presentes na dimensão de competências a serem desenvolvidas pelos próprios pesquisadores são de ordem mais profunda e talvez representem os maiores impasses. Aqui temos presente, a título de introduzirmos o tema, pelo menos três níveis de desafios: o processo de criação e manifestação multimidiática dos conceitos refletidos, a programação em software de autoria como uma nova "escritura" e o conseqüente oferecimento não linear/interativo para o usuário consumidor do pensamento científico. Portanto, não teríamos mais a matriz verbal em seu formato de escrita impressa como o principal recurso à produção e à oferta do 
conhecimento desenvolvido. Agora teríamos, como fruto de uma revisão da metodologia tradicional anunciada acima, a incumbência de produzirmos nosso pensamento a partir de uma "leitura" e de uma criação hipermidiática. Temos que enfrentar os desafios imensuráveis da compreensão e da criação que interprete e produza imagens, vídeos e áudios em formatos híbridos, como expressividades da relação entre teoria e objetos de pesquisa. Por fim, as grandes empreitadas epistemológicas da transformação desses processos ${ }^{10}$; uso aqui o termo epistemologia no sentido de marcar a necessidade de criarmos uma releitura teórica do conhecimento científico, que seja compatível com a promoção das mudanças institucionais e incentive e justifique o desenvolvimento das competências necessárias à criação de ambientes digitais com aval das instituições científicas.

Um outro desafio epistemológico pode ser identificado na etapa de construção de ambientes dialógicos e não-lineares, expressos nas estruturas interativas compostas por subjetividades interconectadas. Os fundamentos epistemológicos ainda nos trazem o desafio do sistema de construção de pensamentos em equipe aberto a intervenções. ${ }^{11}$

Enfim, todas estas questões merecem um aprofundamento de suas fundamentações. Para que isto seja possível, inauguro aqui níveis de conhecimento que podem ser nomeados de filosófico-teóricos, teóricometodológicos, metodológico-teóricos e técnico-metodológicos. O nível filosóficoteórico explora os conceitos em suas relações entre teorias científicas e fundamentos filosóficos. O nível teórico-metodológico tem como fundamento ser apresentado a partir da teoria definida pela pesquisa em questão. Já a abordagem técnico-metodológica enfatiza a praticidade analítica dos conceitos teóricos, sobretudo visando a formação (e a consequente avaliação) de um método próprio de pesquisa. ${ }^{12}$

Neste momento, pretendo apresentar a proposta de adoção de uma taxionomia às estruturas digitais, que seja passível de aplicação aos temas teórico-documentais ou, como intitulei acima, teórico-metodológicos (como argumento, entorno e relação entre programação de autoria e expressividades hipermidiáticas) ou técnico-metodológicos (como o contexto das imagens e do áudio). Tal empreitada pretende inaugurar a proposta tanto de criação e de produção de trabalhos científicos em hipermídia, como também a proposição de critérios de avaliação para tais produtos.

\section{$\mathrm{O}$ argumento}

Propor um argumento que sustente o objetivo da construção de um ambiente interativo depende do direcionamento temático que delegamos ao lugar, o onde, no qual o tempo se perde da linearidade do plano e se encontra com a reticularidade de um ambiente interativo. É a fase primordial da reflexão científica em hipermídia. Momento em que planejemos o contexto imagético (tridimensional ou não) no qual habitarão as interações.

\section{O entorno}

As estruturas digitais de criação híbrida de imagens, áudios, vídeos e programações têm possibilitado a criação de um pensamento que, apesar de anunciado por vários filósofos, ${ }^{13}$ antes da década de 90 , nunca havia sido explorado por meio da utilização de recursos digitais. É bem verdade que as 
potencialidades são tecnológicas, mas as condições de criação e produção são conceituais. Ao contrário do que definira a filosofia iluminista, aqui devem ser possíveis o encontro entre estética e conceito e, quiçá, o próprio desaparecimento destas categorias, por representarem hoje em dia muito mais paradigmas que congelam do que abrem caminhos. A construção conceitual do entorno, baseada em momentos que relacionam o universo multimidiático com as condições de interatividade oferecidas por um ambiente, representa um dos momentos fundamentais da configuração de uma obra hipermidiática. Do aspecto bem-sucedido desta construção depende a atuação do conceito de imersão. Defino imersão como o processo deflagrado a partir da relação entre a subjetividade expressa na criação dos ambientes digitais e a possível acolhida da subjetividade alheia, fundamentalmente, na forma de relações dialógicas como estranhamentos, buscas, referências ao cotidiano, abstrações configuradas e interações programadas conceitualmente. Imersão, portanto, é a condição de habitação revelada por toda experiência de construção, que se expressa por meio do jogo da relação de sentido entre ambiente e usuário, entre conceito e experiência.$^{14}$

\section{Relação entre as soluções de programação e a expressividade hipermidiática conceitual}

A criação de um gênero hipermidiático enfrenta, ao mesmo tempo, o desafio da repetição e a estética do "sempre outra opção", o estático e o contemplativo e o écran interativo, a conjuntura do autor e a autoria efêmera, o significante narrativo e a reticularidade a partir da qual sempre outro significante pode emergir, a imersão do abandono no sentido "dado" e a desconstrução da própria morte do retorno do sentido que, alhures, grita para se manifestar. A autoria que irrompe da relação entre programação e construção imagética e entrega-se e se organiza no mesmo movimento do encontro e do desencontro das interpretações associativas a partir da obra, semiose ilimitada que vai da criação à "programação final". O final é simplesmente a hora de suspender o tempo da compreensão, assim como o seu início está imerso num modesto recomeçar. O desafio desta classificação está associado às condições possíveis da relação entre variáveis e funções de programação e uma expansividade hipermidiáticosígnica dos conceitos e premissas teóricas que foram adotados pela obra científica em questão.

\section{Formação e demonstração dos bancos iconográficos}

Imagens citadas

Uma imagem citada no interior dos argumentos semânticos da tradição de navegação não-linear não pode existir somente como uma ilustração ou representação de um conceito. Como na análise que faz Foucault da obra As Meninas de Velázquez, ${ }^{15}$ devemos buscar uma interlocução entre a imagem em questão e a imersão conceitual em um determinado universo de sentidos. É importante enfrentarmos a questão de que habita, na imagem, uma usina de signos que transcende, em muito, o que é experimentado por cada um e é justamente por isso que, cada vez mais, se torna presente a manifestação de qualquer sentido. Tal como a relação de Foucault com a obra de arte, a imagem na estrutura hipermidiática deve possi- 
bilitar a ação imersiva da navegação, como se estivéssemos no interior de uma obra de arte e, dali, falássemos sempre em nome de um universo conceitual como faz o filósofo, nunca em nome do universal de um conceito. As imagens citadas no interior de ambientes digitais são definidas como a manutenção da integridade imagética do "referente original", mas que, quando inseridas num ambiente hipermidiático, transformam-se numa peça dos jogos de linguagem. Como ocorre com os conceitos teóricos num mestrado ou num doutorado.

\section{Imagens manipuladas}

Na hipermídia, a ação da historicidade, presente naquele que imerge numa imagemmontagem, reforça, mesmo que involuntariamente, o componente essencial de que a imagem deve ser sempre entendida como uma colagem que se abre e se redobra em circularidade sígnica. Mesmo em suas definições mais simples, a imagem na hipermídia perde qualquer característica do "em si". ${ }^{16} \mathrm{~A}$ manipulação é o melhor testemunho contra a dimensão estática da imagem e da resistência aos cânones taxionômicos da história da arte que identificam o conceito de estética com o de sensibilidade irracionalista. A imagem manipulada no interior de horizontes hipermidiáticos expande sempre sua significação para outro lugar, da mesma forma que ocorre com qualquer acontecimento artístico. ${ }^{17}$ No entanto, este "outro lugar" deve fazer parte do mesmo ambiente, sem precisarmos apelar às rupturas institucionais entre arte e ciência. ${ }^{18}$

Imagens reticulares

A imagem reticular no interior de um mundo hipermidiático é o que poderíamos chamar de imagem aberta, imagem caminho, multimargem imagética, um processo denegador, que sempre remete para uma outra interatividade a partir de si mesmo. ${ }^{19} \mathrm{Ja}-$ mais deve ser possível criarmos uma imagem que valha por si, pois é impossível mantê-la imaculada de outros significantes. As imagens reticulares num sistema hipermidiático devem ser o resultado de uma rede irmanada de conexões imagéticas e antiobjetivas, na qual algo de inconsciente tem a oportunidade de continuar sua teia de significações. Uma espécie de lexia do imaginário relacionada essencialmente com as opções de programação. ${ }^{20} \mathrm{~A}$ reticularidade na imagem é proporcional à noção de rede de significantes. ${ }^{21}$

Da imagem reticular, jamais deve surgir "simplesmente" um complemento, mas aberturas para outros caminhos; jamais conclusão, mas multiplicação de juízos; jamais o agora como congelamento, mas o agora como magma que, num rumo indefinido, se petrifica como o a priori da erosão dos sentidos, o jetzt benjaminiano, que se fundamenta numa noção de reconstrução, cuja articulação deve ser totalmente compatível com a noção de ruínas. ${ }^{22}$ As imagens reticulares são redes.

\section{$\mathrm{O}$ áudio}

As locuções e o ilocucionário

São pegadas múltiplas de restos sonoros. Fragmentos de frases que assumem sua condição de incompletude significante. ${ }^{23}$ Conceitos soltos, embora situados nos horizontes possíveis da reticularidade imagética. Sua estrutura é a do jogo sígnico, e seu sentido não se completa na sonoridade de suas manifestações, mas sim em sua condição existencial de corte, de ruptura e de irrupção. 
Toda referência ao fragmento faz da nãolinearidade a interrupção abrupta da seqüência do próprio olhar que, perdido em meio a um universo sonoro, reconduz nossa compreensão sempre para um outro som. ${ }^{24}$ As locuções devem explorar igualmente o locucionário e o ilocucionário. Não há estrutura de navegação que possa se reconstituir pela negação do ilocucionário.

\section{Efeitos de transição (passagens)}

As passagens são transições que têm o compromisso de mudar o estado de consciência no processo reticular de imersão. Concomitantemente, antecipam o novo ambiente e "se despedem" de um lugar. Tal como o conjunto de eventos na hipermídia, os efeitos de transição não podem abandonar, mesmo no corte musical, o mundo no qual habitam. O conjunto de eventos depende muito das interações de transição. Não podemos pensar em ambientes hipermidiáticos em que as transições não foram criadas, localizadas e mesmo modificadas, em função dos cortes e recortes a que se propôs o projeto. ${ }^{25}$

Rotatividade sígnica em texturas musicais

A rotatividade sígnica em texturas musicais na hipermídia renova toda concepção de criação à medida em que se adapta à relação entre interatividade e reticularidade. A possibilidade na qual me debruço é a que se apresenta por meio da edição de palavras-chave (como evento de locuções) presentes nas texturas e na própria navegação. ${ }^{26}$ Nesta definição, a textura se transforma em "trilhas" construídas muitas vezes a partir da mesma estrutura de áudio, como se nos fosse possível sobrepor texturas de forma randômica na mesma imagem.

\section{Cacos}

Pedaços e fragmentos de fonemas, de notas, de palavras ou de ruídos, ou de todos eles juntos numa só irrupção. Todo horizonte se constrói com fragmentos, inevitavelmente. Randomizar os cacos de áudio pode representar o processo de atribuir probabilidade proporcional a todos os pontos na programação, fragmentação e expressividade do conceito em questão.

\section{Randomismo}

As opções de oferta das estruturas criativas, a partir de componentes aleatórios de programação, podem ser definidas pelos caminhos conceituais que regem tanto a sistematização quanto a oferta dos conteúdos numa hipermídia. O randomismo pode ser definido como o processo pelo qual os fenômenos da improbabilidade e da probabilidade dos eventos adquirem proporcionalidade, sendo oferecidos em todos os pontos interativos do ambiente. ${ }^{27}$ Tal característica, estando ativa durante a navegação, cria uma estrutura de acidentalização para o surgimento do universo sígnico. É justamente a soma do aleatório com a improbabilidade e com a acidentalização que melhor conceitua o randomismo na hipermídia.

A taxionomia anunciada acima tem por objetivo propor critérios de criação e de avaliação do trabalho científico em hipermídia. Veremos que, no Brasil e na Alemanha, existem obras que seguiram o caminho do aprofundamento da aplicação dos recursos digitais no meio científico, partindo de utilizações muito modestas, até obras que exploraram analiticamente a relação entre objetos de pesquisa e referências teóricas. No entanto, não necessariamente os critérios 
identificados aqui foram seguidos pelos coordenadores dos projetos. Em muitos casos, houve preocupações com a complexidade de algumas das etapas metodológicas, mas, em grande medida, as produções hipermidiáticas analisadas neste artigo devem ser consideradas mais como experimentações do que como criações e produções científicas totalmente ratificadas pelas instituições.

As transformações anunciadas pela relação entre ciência e hipermídia exigem um restabelecimento das associações possíveis entre filosofia, teorias, métodos e técnicas. A chave desta retomada está localizada na extrema ruptura com uma tradição das instituições científicas dos últimos três séculos, que convencionaram associar logicamente o conceito de verdade científica com a composição metodológica do texto escrito e impresso.

Os próximos desafios estão localizados nos seguintes níveis:

a construção da análise da relação entre fundamentos filosóficos e a atuação de teorias científicas; fazem parte deste nível os temas que envolvem ética e esteticamente as abordagens transdisciplinares das relações entre homem-máquina, entre homem (estruturas de comunicação) e meio (sobretudo os fenômenos midiáticos considerados globais), entre produções artísticas (arte digital) e historicidade cultural (aqui as diversidades entre regiões são mais significativas do que entre países);

a relação entre teorias científicas e propostas metodológicas da construção de ambientes e interatividades digitais; temos, neste momento, o tema da produção do conhecimento em equipes, o desafio da associação entre conjuntos conceituais e cami- nhos construtivos e, por fim, a operacionalidade institucional das relações possíveis entre produção e divulgação de conhecimento;

a relação entre os métodos de análise e as técnicas da lide com instrumentos digitais; estes desafios predizem opções
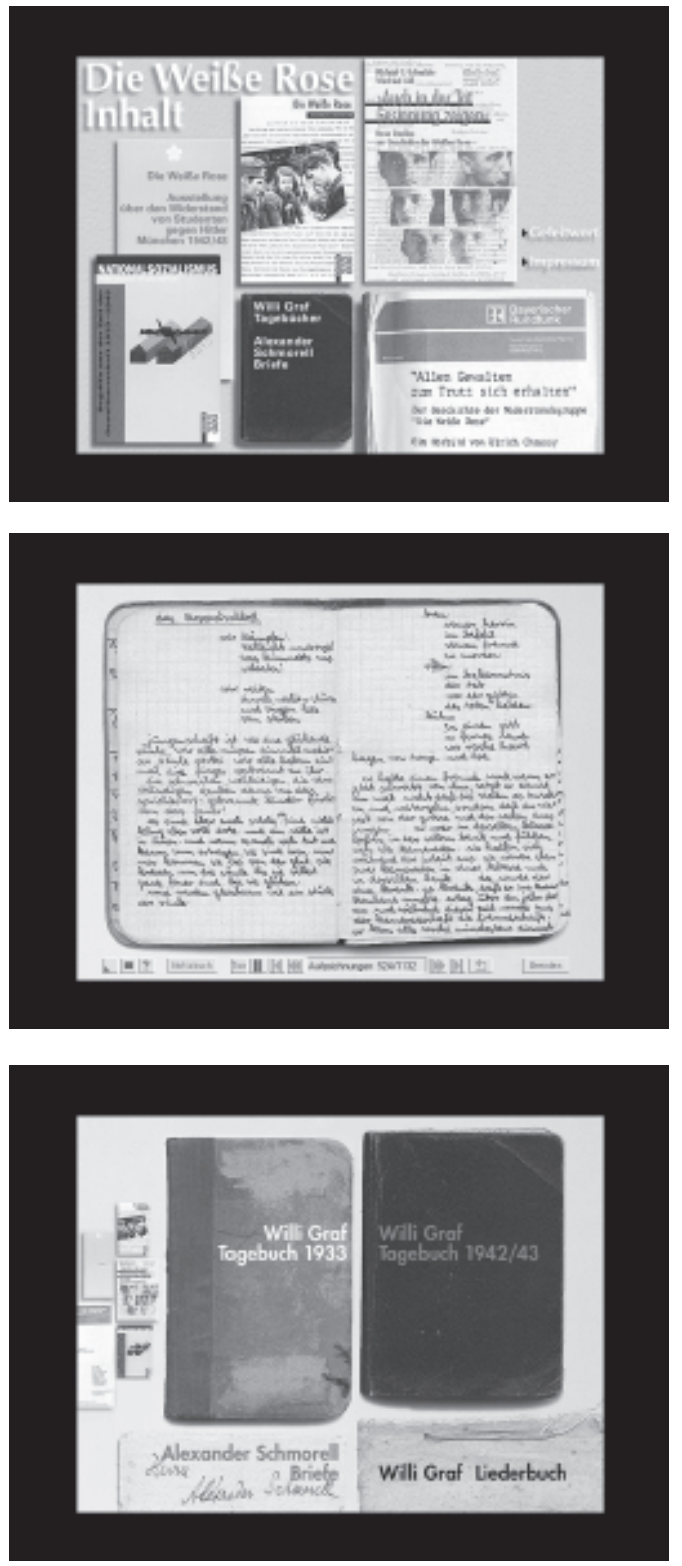
metodológicas como pólo de diretrizes ao uso de recursos tecnológicos.

\section{Desvelamento multimídia de interfaces digitais}

Na primeira metade da década de noventa do século passado, tivemos as primeiras grandes experiências com as potencialidades hipermidiáticas no âmbito acadêmico. ${ }^{28}$ Foi um momento de experimentação que nomeio como desvelamento multimídia de interfaces digitais. Neste momento, tanto no Brasil quanto na Alemanha já tínhamos vários produtos no mercado, sobretudo enciclopédias que apresentavam sua versão digital. ${ }^{29}$ No entanto, no meio acadêmico da pesquisa universitária, ou em convênio com este, emergiram alguns trabalhos que procuraram utilizar os recursos multimídia em prol da sistematização e/ou apresentação de conteúdos. As propostas estavam em torno da citação de imagens, de áudio e de vídeos como complemento de textos analíticos que expressavam pesquisas desenvolvidas nas universidades. É o caso de Die Weisse Rose que apresenta temas referentes ao nacional-socialismo. Neste trabalho, a organização temática é apresentada numa seqüência de textos e de imagens que, apesar de serem oferecidos em estrutura linear,

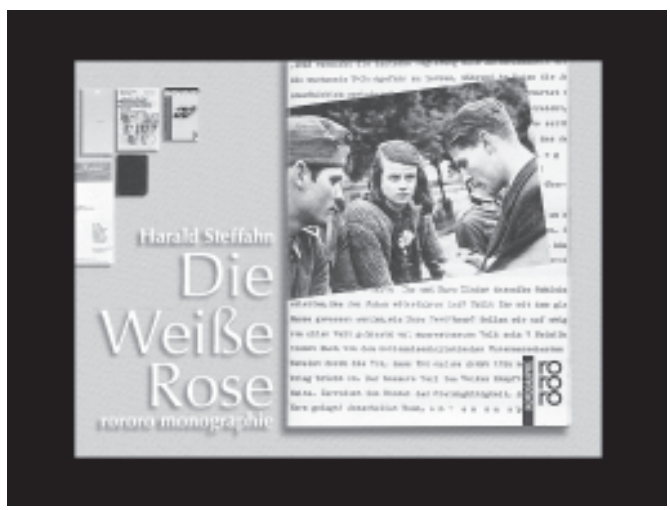

já exploravam uma construção imagética de montagem..$^{30}$

A estrutura de montagem entre textos e imagens propõe uma relação de autoreferencialidade. Os temas centrais, que se localizam nos dilemas estudantis diante do nacional-socialismo, nos são oferecidos a partir da análise desde os cadernos escolares até os movimentos organizados pelos estudantes. Nesta estrutura digital, passamos por mais de 1500 páginas de textos e centenas de imagens. Especialmente no caso das imagens, é muito significativo o trabalho de tratamento do design das páginas, que geralmente são compostas pelos próprios documentos de época, incorporados como parte da explicitação do conteúdo.

O argumento do trabalho segue a tópica de uma noção de documentação como história do cotidiano. ${ }^{31}$ Haja vista que boa parte de suas argumentações apresenta documentos cotidianos tal como os diários de Willi Graf de 1933 e o de 1942/43. De uma certa forma, podemos dizer que a imersão num documento, como um diário, possibilita a ação de um conjunto de signos verbais e visuais com uma porção ilocucionária muito conseqüente. O entorno é definido com colagens de diários, matérias jornalísticas e fotografias de época, muitas tiradas pelos próprios estudantes.

A relação das soluções de programação e a expressividade hipermidiática conceitual é trabalhada em formatações que propõem criar uma mimesis de monografias, oferecendo associações entre o ato do registro de situações cotidianas e a interpretação de fatos históricos presente em monografias universitárias. ${ }^{32}$ Neste trabalho houve uma grande preocupação com a formação e apresentação dos bancos icono- 
gráficos: os documentos são classificados e são oferecidos recursos de análise da documentação por meio de ampliações e abordagens comparativas. A categoria de imagens citadas é a mais presente, e a de imagens manipuladas é utilizada medianamente, cumprindo o papel de servir de base como interface para os textos. O áudio é explorado tanto como registro de depoimentos como uma interlocução com as imagens e textos complementares. As opções de navegação, além de apresentarem os recursos de mudança de paginação e sistemas de busca, ainda oferecem lugares para anotações e comentários, localizados nas páginas em que existem registros nos diários.

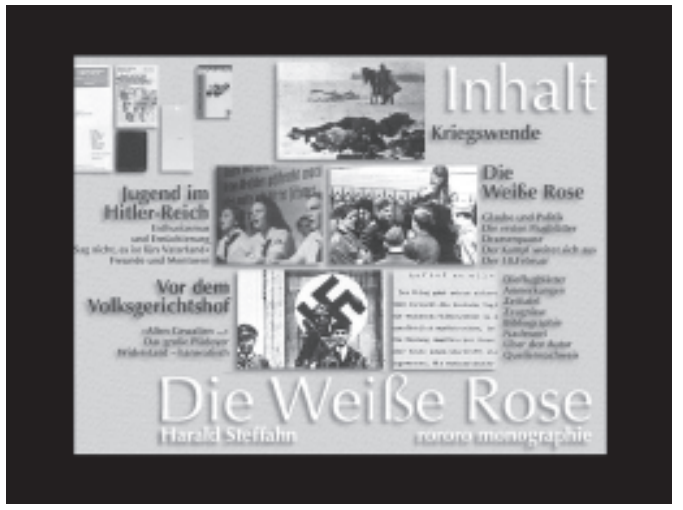

A interatividade do Die Weisse Rose e sua geração de obras digitais ainda não exploravam uma complexidade maior do entorno como proposta ${ }^{33}$; ainda não era um trabalho que aprofundasse as relações entre as soluções de programação e a expressividade hipermidiática conceitual, nem mesmo que apresentasse um grande grau de reticularidade às imagens. ${ }^{34} \mathrm{~A}$ utilização dos recursos de áudio localiza-se no interior dos clássicos modelos de locuções ou depoimentos. No entanto, ao contrário do que pode estar parecendo ao leitor, minha opi- nião é que o trabalho é excelente por integrar uma proposta da linha de história do cotidiano $^{35} \mathrm{com}$ a construção/colagem de imagens e textos como documentação. Neste sentido, até mesmo os efeitos de transição das páginas fazem parte de uma proposta de construção sígnica que remete às anotações nos diários e suas interlocuções com a documentação pesquisada.

No Brasil, o trabalho Cultura e memória ${ }^{36}$ também elegeu a relação entre registro documental e interatividade, como a principal estratégia de abordagem temática.

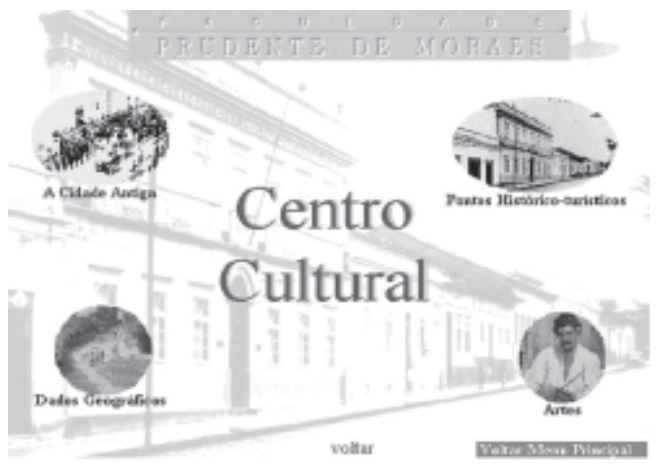

O argumento procurava revelar as relações entre arte, geografia, política, urbanidade e historicidade, a partir de um ponto em comum: a cidade de Itu no interior de São Paulo. As preocupações com o entorno ocorreram mesclando obras fotográficas com pinturas de Almeida Jr. Ou seja, a geografia era introduzida por obras de artes plásticas, a política por fotografias, a pintura por retratos e a historicidade por colagens.

A opção mais completa em nível de registros trata-se do menu Artes, em que podemos encontrar desde o cinema produzido na cidade, passando pela pintura de artistas importantes do Romantismo brasileiro como Almeida Jr., até mesmo o desvela- 


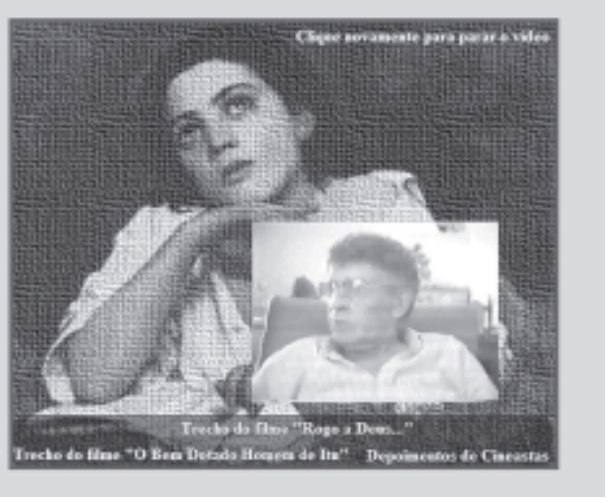

mento de compositores clássicos na cidade como Elias Álvares Lobo (1834-1901) e Tristão Mariano da Costa Jr. (1880-1935). O conhecimento do cinema desenvolvido na cidade é apresentado a partir de depoimentos recolhidos por conhecidos atores da região. É o caso do comediante Simplício que chegou a participar de mais de dez filmes realizados em Itu. Os filmes mesclavam uma linguagem popular com intenções comerciais, como os filmes Rogo a Deus e meto bala ou $O$ bem dotado homem de Itu. A cidade acabou sendo conhecida no cenário nacional como lugar do superlativo hiperbólico. ${ }^{37}$ De uma certa forma, houve uma mescla entre o popular superlativo, a política e as artes. Portanto, para que fossem atingidos os objetivos definidos no argumento do trabaIho, foi necessária a formação de um grande banco multimidiático, indicado por pesquisas e entrevistas realizadas na região. ${ }^{38}$ Ainda é importante realçar que, como se tratava de um trabalho inaugural, no sentido de não haver no Brasil nenhum similar até então, foram apresentadas reflexões sobre a importância da relação entre os bancos multimidiáticos e um conceito de memória. Temas como biblioteca digital, bancos digitais e programação multimídia foram abordados a partir da relação com um conceito de biblioteca digital especializada em história local.

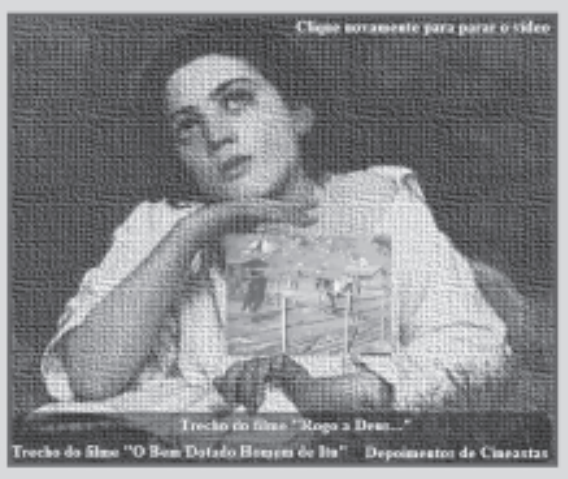

Neste sentido, o tema que apresentava a obra de Almeida Jr. procurou realizar um movimento circular temático da obra para o contexto do romantismo brasileiro e desse para o movimento romântico na pintura francesa, voltando para o regional em Itu. ${ }^{39}$

$\mathrm{Na}$ tela que apresenta parte da obra de Almeida Jr., temos uma composição na forma de exposição temática. Como se fosse uma parede de museu onde as obras pudessem ser admiradas, tanto em sua unidade temática, quanto em sua individualidade expressiva que oferecesse a opção de acesso aos detalhes de cada obra. A relação das soluções de programação e a expressividade hipermidiática conceitual está ensaiada nas opções de colagem e de acesso interdisciplinar no jogo entre política, arte, história local e depoimentos. A composição imagética, portanto, é de imagens citadas e manipuladas que compõem um mosaico-registro da diversidade das manifestações culturais da região. O áudio está a serviço de um conceito de registro digital.

\section{Demonstração de estruturas estéticas hipermidiáticas}

Os momentos posteriores marcaram novas e radicais experiências com os recursos digitais no mundo acadêmico. Este mo- 


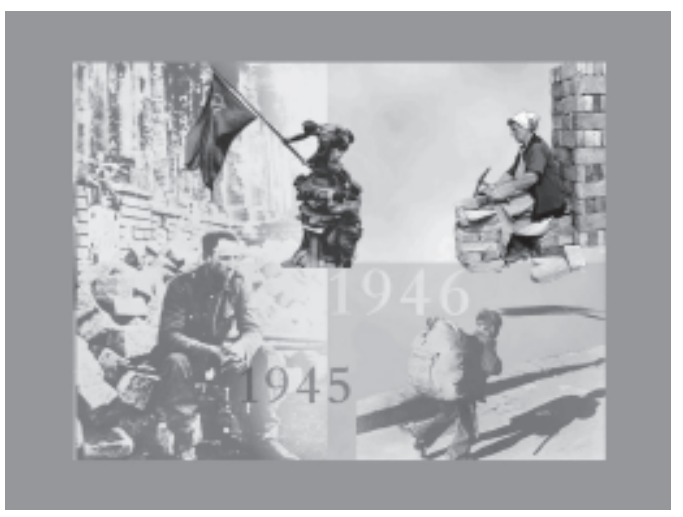

mento, nomeio de demonstração de estruturas estéticas hipermidiáticas. Foram alguns trabalhos entre Brasil e Alemanha que construíram os novos caminhos desta abordagem. Nestas obras, o nível de complexidade está relacionado com uma exploração mais aprofundada da linguagem de programação como parte das propostas demonstrativas..$^{40} \mathrm{O}$ ambiente hipermidiático seria um lugar de compreensão que dependeria basicamente da decifração de desafios interativos por parte dos agentes. Neste momento, ainda se manifestava uma grande tensão entre a construção de narrativas lineares e a desconstrução temática possibilitada pela própria navegação em suas expressividades não-lineares. ${ }^{41}$ É o momento em que houve grandes aproximações da pesquisa científica com propostas poéticas e com produtos educacionais, sem que se perdesse o vínculo com a concepção de pesquisa acadêmica, já que esta é a questão que está norteando todo este texto.

Como uma espécie de soma deste momento com os anteriores, temos, por exemplo, o trabalho Deutsch, Deutsche, Zeiten / eine chronik. ${ }^{42} \mathrm{O}$ argumento deste trabalho concentrou-se no âmbito do encontro entre história e sociologia, apresentando uma linha de tempo que percorre a história da Alemanha de 1945 a 1995. A intenção foi manter-se fiel ao conceito de narrativa presente na crônica como estilo literário. $\mathrm{O}$ entorno recebeu uma proposta que emula um movimento circular $\left(360^{\circ}\right)$ situando o agente em meio a um grande composto de montagem imagético que, apesar de ser diacrônico, tem seu princípio linear subjetivado pela própria possibilidade de navegar pela grande estrutura circular de menu. Lembrando a estrutura do story board, as imagens são compostas na dependência da linearidade seqüencial, como se fossem textos narrativos, ou seja, imagens manipuladas do final da guerra apresentam a inserção de imagens manipuladas da presença russa que, por sua vez, juntam-se a imagens que remetem às idéias de fuga e de reconstrução. ${ }^{43}$ Nesta obra, estão presentes narrativas que exploraram locuções lineares a partir de cada época abordada. Temos, portanto, várias opções de menu demonstradas também com versões imagéticas, mesclando princípios que entendem concomitantemente a história como narrativa linear e circular.

Há uma soma de horizontes verticais com horizontais definidos, por ano, desde 1945. Uma simples observação do trabalho identifica, por exemplo, o ano de 1945 se sobrepondo graficamente ao ano de 1946 e uma imagem que expressa a chegada dos russos ocupando o meio vertical que separa os dois anos. Tais propostas estariam num nível ainda muito limitado, se não fosse o fato de este ambiente estar imerso numa barra de opções que se apresenta perpétua.

A barra interativa oferece opções de acesso a grandes bancos de imagem e textos históricos. Há uma colaboração de vários arquivos de documentação da Alemanha, como o Deutschen Rundfunk-archiv, o que 


\section{ARCHIV

possibilitou a reunião de centenas de arquivos de imagens históricas e de áudios significativos de cada época. A classificação dos arquivos é dada pela proximidade temática que relaciona história e sociologia e, neste contexto, por exemplo, a fotografia é trabaIhada como documento histórico.

O equilíbrio no interior do entorno circular entre imagens manipuladas, imagens citadas e programação nos oferece um nível muito conseqüente de imagens reticulares. As imagens não são apenas citações fotográficas, mas citações que emergem de ambientes que criam um lugar para habitarem. ${ }^{44}$ Também é interessante, nesse
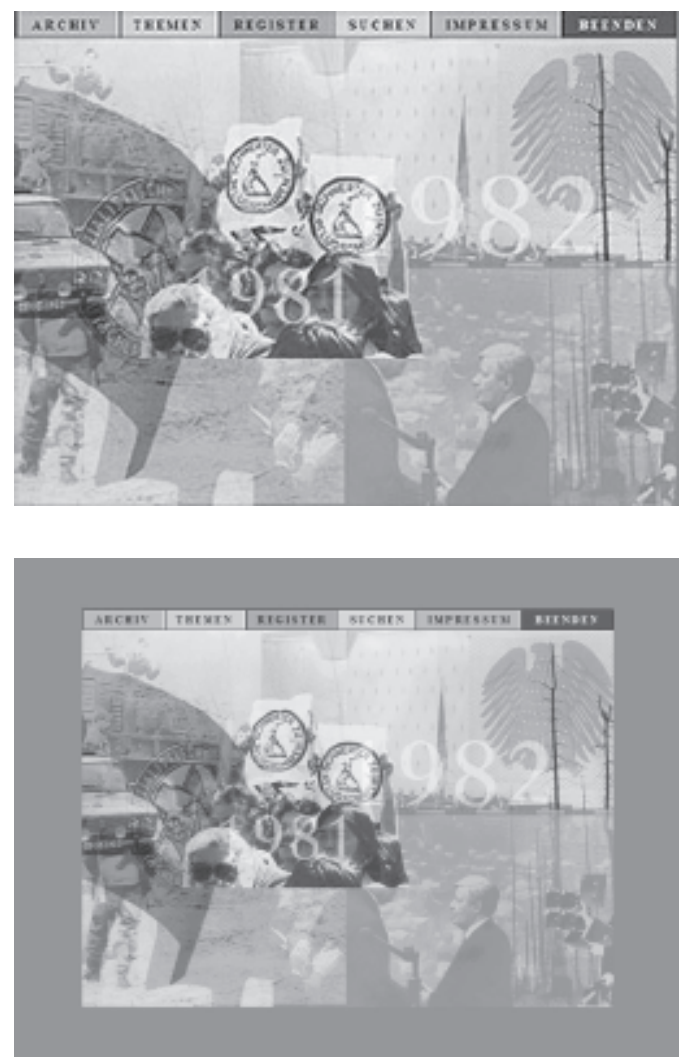

trabalho, a preocupação com sistemas de busca que fornecem uma taxionomia temporal, conceitual e imagética. Qualquer busca, a qualquer momento, pode ser ativada clicando no botão direito do mouse, o que reforça a responsabilidade da existência de uma rede de conexões que adquire a característica de relacionar o conteúdo imagético com o sonoro. Esta seria a associação do ambiente imagético com o que poderíamos chamar de uma lógica da busca ou da pergunta, como se trabalhássemos com o "simples" princípio de que quem pesquisa constitui seu saber mais a partir de perguntas do que de respostas. Neste tipo de trabalho é a ação do perguntar que cria a interatividade, princípio que estaria presente em vários trabalhos no futuro, como veremos. Há um certo compromisso recíproco de abertura de ataIhos entre todos eventos presentes nesta obra digital, a ponto de evitar que um conceito de complemento impere entre os diversos estágios interativos. ${ }^{45}$ Neste sentido, não podemos delegar nem mesmo às fotografias de referência histórica a condição de complemento, pois a idéia apresentada pelo trabalho no tocante às imagens citadas é que surjam como documentação.

O áudio, apesar de seguir o princípio narrativo, tem a colaboração de um universo ilocucionário garantido pelas interatividades imagéticas e de programação. Com isso reforçamos a idéia de que mesmo estruturas, aparentemente tradicionais de utilização de imagens e de áudio, podem transcender a obviedade da citação e da narrativa, quando inseridas num entorno que se apresenta como uma demonstração de estruturas estéticas hipermidiáticas. Es- 
sas são algumas das razões que fazem com que a utilização de recursos de imagens/ montagem em $360^{\circ}$ não tenham uma característica de gratuidade em sua utilização, já que, mediante todas as propostas teóricas interativas da narrativa dos sistemas de busca, a concepção da rotatividade de opções está garantida de forma qualitativa. Portanto, sendo apresentados os resultados da relação entre o processo criativo e as abordagens conceituais, só então poderíamos imaginar o aprofundamento da utilização dos recursos tecnológicos. Este trabalho, sem abandonar suas definições de argumento, poderia ter explorado mais radicalmente a criação de ambientes tridimensionais como composição do entorno; ou, ainda, poderia oferecer opções de registro para comentários individuais e complementares quanto aos textos que descrevem o conteúdo. Enfim, Deutsch, Deutsche, Zeiten / eine chronik aponta para a composição interdisciplinar entre história e sociologia, misturando diacronia e sincronia ao ponto de descaracterizá-las, igualmente como encontramos nas relações contemporâneas entre ambas as ciências, como se nos fosse possível, a partir da criação e da programação, demonstrar nossas tendências e interpretações epistemológicas a partir do próprio trabalho investigativo.

Neste momento, tivemos no Brasil uma obra digital muito significativa, como investigação na área de Filosofia da Universidade Federal Fluminense. Trata-se da obra Univvverrsso Gentileza - A gênese de um mito contemporâneo. ${ }^{46} \mathrm{O}$ argumento está todo voltado para a trajetória do Profeta Gentileza que, na verdade, é José Datrino, exempresário carioca, que, após presenciar o incêndio de um circo, teve uma "iluminação divida" que o orientou para que se transfor-

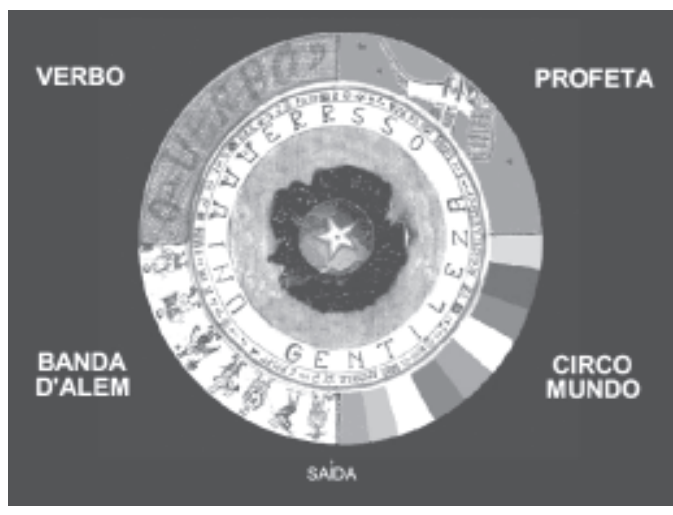

masse num profeta. A partir daí, Gentileza virou peregrino e criou um mundo próprio de expressividades artísticas como estratégia para divulgar suas profecias.

A força do argumento indicou também a construção de um entorno extremamente poderoso para este trabalho: um circo. Logo na tela principal de acesso, temos as quatro opções que irão demarcar não somente a navegação, mas também os referenciais teóricos utilizados pelo autor. Deleuze, Derrida, Heidegger e Cassirer ${ }^{47}$ são alguns filósofos que embasam a interpretação de todo o processo criativo de Gentileza. O entorno, sendo um circo, presentifica a idéia de circularidade de multiexpressividades artísticas, que englobam desde a música, a poesia escrita, a oral e suas relações com a posição mítica de Gentileza. Ao começarmos a exploração de cada uma das opções desta primeira tela, temos uma imersão no próprio processo criativo do Profeta. É interessante notar como algumas opções de criação do design foram pensadas e produzidas partindo da própria obra do profeta.

Na maioria das opções, a demonstração é garantida com a conjunção de depoimentos de Gentileza, em vídeo e em texto, 
inclusive seguindo as orientações da própria tipografia criada pelo profeta. Esta opção é muito conseqüente no sentido de proporcionar às imagens uma característica reticular, pois fica muito claro, tanto na programação quanto na criação das telas, por um lado, a ineficiência das imagens ou textos se avaliados individualmente e, por outro, a ratificação, a todo instante, de que esta obra digital é uma habitação, um lugar onde deveremos nos movimentar e buscar conhecer. ${ }^{48}$ A casa do universo criativo da personagem analisada.

A relação das soluções de programação e a expressividade hipermidiática conceitual estão imbricadas com um conceito de estandartização do mundo em suas características populares e superlativas. É imenso o mundo significante de Gentileza: o mundo, o amor, Deus, a paz etc. são componentes de uma estética que precisa ser resgatada em sua obra que tem esta missão. Por exemplo, na opção circomundo, está presente um jogo que faz referência ao incêndio do circo, leia-se mundo (em 1961) e à necessidade de reconstruir o mundo, leiase circo. Aqui temos mais um exemplo de soluções extremamente simples de programação que estão a serviço de interpretações teóricas complexas. ${ }^{49} \mathrm{~A}$ interatividade está

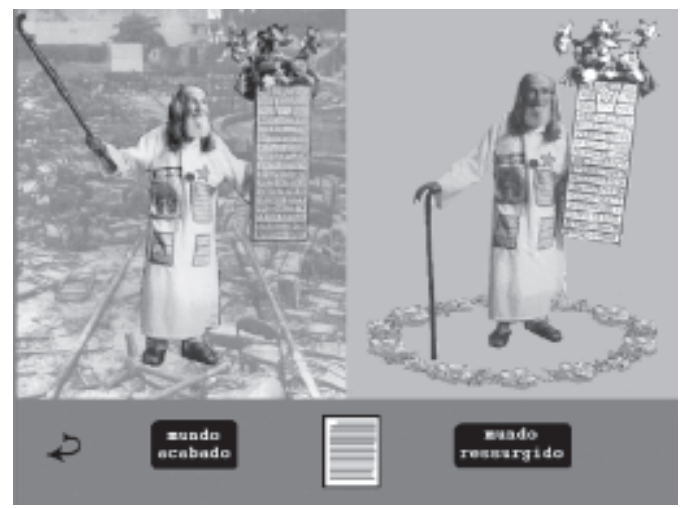

garantida não pelos movimentos de acesso a cada opção, mas pelo conjunto da obra do Profeta e da interpretação desta por parte do autor. Há uma proposta de manter um certo paralelismo entre os processos criativos de Gentileza e de Leonardo Guelman, autor da obra digital. A mistura de imagens citadas com imagens manipuladas, como garantia à existência de imagens reticulares, valoriza o recolhimento feito pela produção dos bancos multimidiáticos e provoca um grande impulso à leitura analítica do trabaIho científico-filosófico, o que, por sua vez, só é compreendido por suas dimensões hipermidiáticas. Começa a ocorrer neste tipo de obra uma espécie de auto-referencialidade entre os processos reflexivos, pois a análise depende do processo de criação "artística" do próprio pesquisador. Neste momento que classificamos de demonstração de estruturas estéticas hipermidiáticas, começa a ocorrer um fenômeno que será preponderante em várias obras: um redimensionamento teórico-conceitual, possibilitado a partir de um processo de criação, que abandonou o verbal-metodológico como expressão fundamental. ${ }^{50}$ Este verbal-metodológico se transforma em inúmeras manifestações sígnicas de fundamento multimidiático que, por sua vez, seriam inalcançáveis se conti-

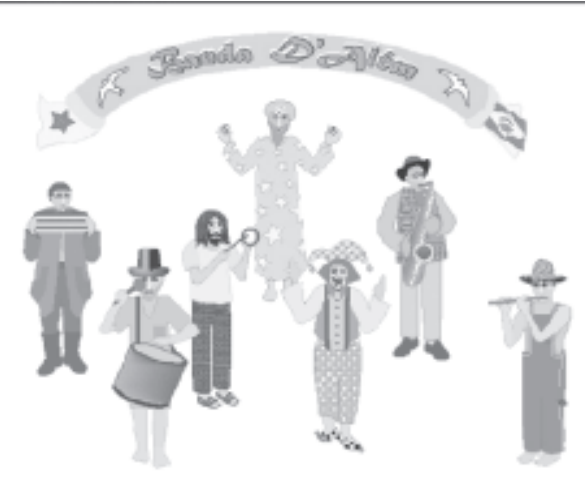


nuassem subabitando o texto impresso. $\mathrm{O}$ trabalho icônico não é mais construído de forma verbal-escrita, mas, fundamentalmente, com imagens e/ou sonoridades, que foram pesquisadas ou criadas, a partir do uso do material documental levantado pelo trabalho de sistematização e classificação dos bancos. Mesmo em suas condições mais simples, como as funções de ir e de voltar, houve preocupações de se trabalhar numa sobreposição sígnica, pois a função tem como seu interpretante imagens que estão no interior de uma cadeia sígnica, definida pelo encontro entre as tendências teóricas com o uso de imagens para as quais thes são atribuídas uma série de associações temáticas. Por exemplo, o mundo como circo e como circularidade se recompõe como ícone, que pode levar à retomada da tela principal, que tem sua expressividade numa imagem de circo. Não há como saber se estas opções foram adotadas de forma consciente por parte do pesquisador, mas o fato é que elas estão presentes somente em função das competências anteriores, tanto teóricas quanto em nível de design. Especialmente neste trabalho, foram adotadas medidas muito curiosas, como um design que emula as criações de Gentileza, como se essas adquirissem existência como linguagem que expressa, desde as opções criativas com imagens e áudio até o desenvolvimento muito característico da tipografia. Talvez devêssemos dar uma atenção maior a esta categoria que estamos nomeando de demonstração, no sentido de procurarmos o caminho da emulação, quando estivermos pesquisando uma fundação de linguagem como é o caso aqui. ${ }^{51}$ Não se trata, portanto, de um simples processo de simulação, mas de refundação, uma apropriação que se manifesta na relação dialógica com os funda- mentos. Por um lado, isso não se apresenta muito diferente da apropriação que estamos acostumados no meio científico, quando em nosso texto inserimos o texto de determinado autor para que fale junto conosco; por outro, temos, na conjuntura da hipermídia, não só a condição de dar maior independência ao autor consultado e ao seu texto como, inclusive, de procurar a expressividade do desenvolvimento estético para conceitos que surgiram a partir de um "acordo" realizado com os autores.

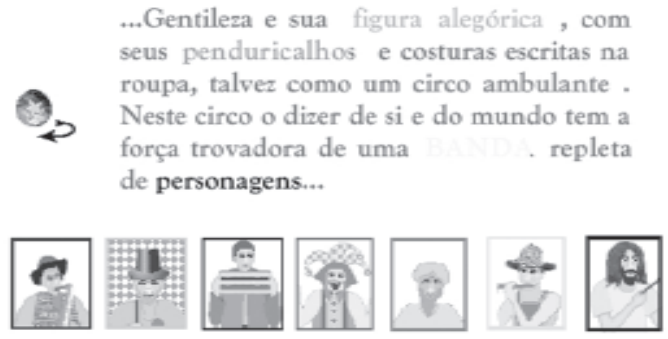

O áudio produzido para esta obra digital contém locuções, efeitos de transição e cacos que se agrupam e se reagrupam em todos os níveis de interatividade. Uma ênfase é dada novamente para o tema do circo, sobretudo por meio de pequenas identidades criadas que podemos chamar, para os ambientes em questão, de vinhetas, na falta de um nome melhor. Esta pesquisa demonstra o quanto podemos explorar, em nível conceitual, a partir dos recursos já existentes. É interessante lembrar, neste contexto, o conceito de longa duração que esteve muito em voga no âmbito das ciências sociais durante a segunda metade do século $X X$. Trata-se do que Fernand Braudel nomeou também como a pluralização da temporalidade. Braudel vê na velocidade do tempo a razão natural-física do solapamento de qualquer ação político-cultural do homem. O ho- 
mem está à mercê da repetição do equinócio, não há o que se fazer diante do determinismo do passado a não ser adquirirmos consciência dele. O homem não constrói seu destino, sua historicidade não lhe pertence, ele é apenas espectador, objeto da geo-história. ${ }^{52} \mathrm{Ape}-$ sar de minha concepção não ser determinista, parece que estamos à mercê de temporalidades epistemológicas que se infiltram nas instituições científicas, à espera de "consensos" para poderem transformar algo. Foi o que aconteceu com a imagem estática, até que lhe fosse permitido penetrar, cada vez mais, no âmbito da ciência. Mas, por outro lado, foi o que não aconteceu com a imagem em movimento que, com raras exceções (como no caso da Antropologia Visual) até os dias de hoje, não teve espaço institucional como expressividade do pensamento científico.

Esta condição começa a mudar radicalmente quando encontramos, por exemplo, trabalhos como Bauen im licht - das glashaus von Bruno Taut, ${ }^{53}$ desenvolvido por professores da Universidade de Postdam (Alemanha). O argumento desta obra digital reúne um grande número de características, que já indicam o processo hipermidiático de construção como concepções conceituais, em praticamente todas as etapas, in-

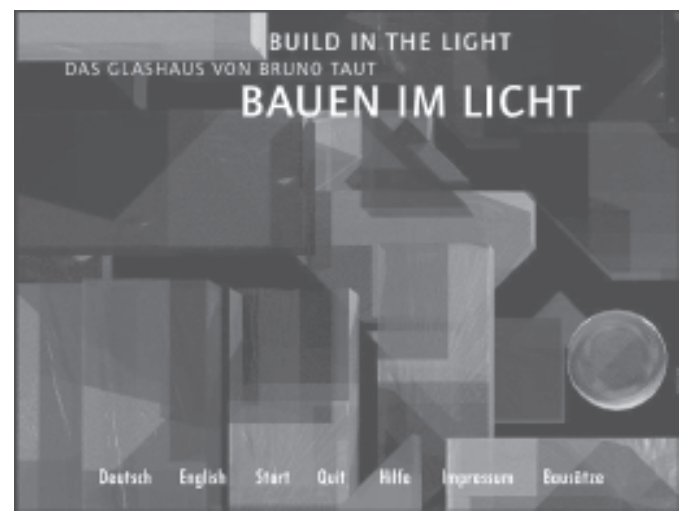

clusive deixando em aberto um nível de interatividade que segue os caminhos indicados pelo próprio processo. São inúmeras as características da obra de Bruno Taut, abordadas na obra digital, que estão demonstradas de forma interativa, questão já explicitamente notada na tela inicial. A tela de acesso à obra apresenta algumas concepções de Taut: a idéia de que as estruturas materiais, em sua arquitetura de cristal, devem proporcionar o encontro entre marco e conteúdo, com o fim de manter a "pureza" e o "vazio essencial" da arquitetura; outra questão que já encontramos nesta tela principal é a decomposição cristalográfica que cede espaço a uma forma contínua, sem fraturas, oferecendo uma identidade de seus múltiplos cortes e reflexos; e ainda poderíamos pensar numa referência às fachadas arquitetônicas que eram entendidas por Taut como a entrada das edificações, como se afirmássemos que a obra arquitetônica começa, sobretudo, em sua exterioridade, "exterior que já é interior". ${ }^{54}$

A imersão nesta obra procura emular o processo conceitual pensado pela arquitetura de Taut a partir da proposta de trabalhar com as cores e transparências, com suas características de imaterialidade, movimento e vazio. Tais concepções advinham das

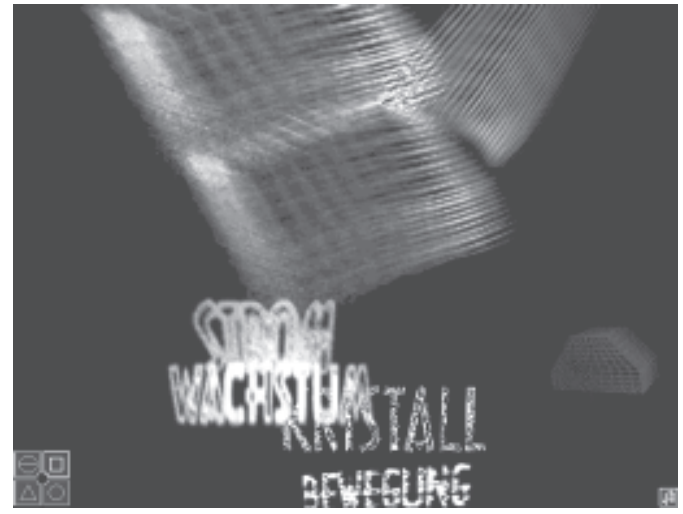


propostas de Taut de unir arquitetura, escultura, pintura e poesia (intenções definidas desde a publicação do número 4 da revista Der Sturm de 1914). Isto deveria acontecer sem que uma expressividade artística ficasse dependente da outra, ou seja, elas deveriam somar sem perderem suas próprias características. Este encontro demonstra, por exemplo, o conceito de construção existente na pintura, ou seja, o processo arquitetônico que se presentifica numa obra de pintura. Outra questão importante está relacionada com a concepção de estrutura; neste sentido, o arquiteto, na opinião de Bruno Taut, assim como já haviam feito os pintores, deveria se libertar da perspectiva. Para tanto, um possível encontro entre a pintura de Arnold Böcklin com algumas obras de Alfred Messel, em estruturas de ferro, já podia ser indicado como o fim da perspectiva na arquitetura. Oscilando entre pintura, arquitetura e poesia, atraíam-no, por exemplo, as possibilidades de construção espacial baseadas em propostas cromáticas. A proposta de anular os limites artificiais entre as artes, permitindo ao arquiteto que, como artista, controlasse o projeto total da obra, foi a base do programa da Arbeitsrat für Kunst, fundada em 1918 pelo próprio Taut. ${ }^{55}$ Uma das melhores expressões disso está no fato de que, naquele momento, toda ordem de artistas agrupados em torno da arquitetura passou a reclamar para si a responsabilidade com a educação da sensibilidade e a aparência sensível do mundo, desde os monumentos até os selos ou as moedas. Ou seja, Bruno Taut e seus seguidores queriam inter-

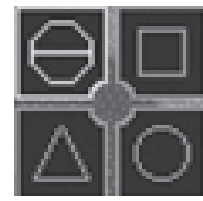

vir nas decisões de políticas públicas que demandavam orientações estéticas de toda a ordem. ${ }^{56}$ Tais características estão manifestadas na criação de Bauen im licht, por exemplo, quando se opta por figuras geométricas simples, como o triângulo, o quadrado, o hexaedro ou o círculo, como recurso de navegação já para o próprio menu de acesso principal. Basta posicionar o cursor sobre uma das figuras que o ambiente todo muda, processo que contém o acesso aos temas principais e que já faz referência ao conjunto de idéias que será apresentado durante a navegação: formas, cores, conteúdos, espacialidade, temporalidade, transparência, vazio, poesia, pintura, montagem e ruptura. Um exemplo disso, podemos ter ao ativarmos o ícone representado pelo quadrado, quando um conjunto de formas geométricas, junto de palavras e composições fraseológicas, começa a ocorrer por inteiro na tela, causando movimentos aleatórios dependentes da movimentação do cursor. As palavras são, por exemplo, cristal, movimento, vazio, poesia, entre outras, e o áudio se presentifica, randomicamente, em locuções sussurradas como construções de colagens significantes. As locuções sussurradas, junto das palavras, frases e imagens fragmentadas, comandadas pelo cursor do agente, elegem o agir construtivo como um dos principais fundamentos da obra de Taut, já que ele acreditava que, apesar dos trabalhos teóricos serem interessantes e estimulantes, todos deveriam se apresentar como trabaIho prático, ou seja, era preciso construir. ${ }^{57}$ $\mathrm{Na}$ opção do círculo, são ativados alguns conjuntos de formas e cores que introduzem os princípios de que a cor tem condições inerentes para tratar categorias como proximidade, distância, espacialidade, contração e, isso, tanto na arquitetura quanto na pintura. Quadros, janelas, portas, aberturas, traços 
de pincel contêm, portanto, algo essencialmente auto-referencial. A execução de obras arquitetônicas, mais que a produção conceitual e física de um prédio, deveria dar a conhecer uma forma artística e interdisciplinar de pensar. ${ }^{58}$ Para Taut, arquitetura e pensamento são tão equivalentes quanto o são pintura ou escrita e pensamento. Com o fim de colocar em questão a materialidade na arquitetura, Taut passa a usar o cristal colorido nas construções. A cor, afirmava, também contém materialidade construtiva tanto quanto qualquer outro material de construção. Os cristais coloridos têm um grande poder de associação por se apresentarem, ao mesmo tempo, transparentes e materializados. Duplicidade que talvez fosse impossível de se revelar de outra maneira. Portanto, vemos, já nestes primeiros momentos de acesso aos ambientes desta obra digital, uma corrente de conceitos teóricos colocada à prova do agente que navega. Este conjunto de ações seria impossível pela escrita, pois os níveis de interatividade são definidos pelas orientações epistemológicas que regem o trabaIho, assim como as metáforas (enquanto hipoícone) em meio a um ensaio científico ou filosófico também podem nos oferecer caminhos que rompem com a lógica da construção textual "coerente" da metodologia científica. ${ }^{59}$

À medida que imergimos mais no trabalho, começamos a perceber que a relação das soluções de programação com a expressividade hipermidiática conceitual também acompanha um aprofundamento analítico das opções abordadas. Um dos exemplos pode ser experimentado a partir da interação com o círculo no menu principal: a imersão no palácio de cristal. Mais um interessante acerto deste trabalho foi a construção tridimensional do Palácio de Cristal de

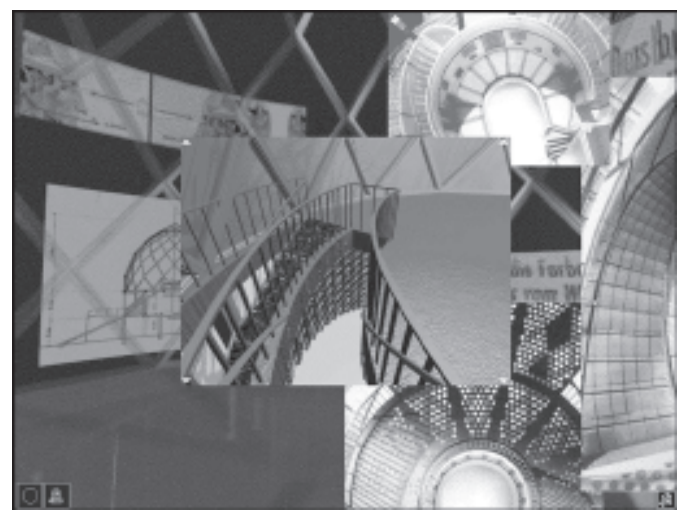

Bruno Taut. A imersão acontece no centro da tela e, enquanto navegamos nas animações em sua volta, são apresentadas imagens dos lugares que compõem o ambiente no qual nos encontramos. Por um lado, a construção tridimensional do Palácio de Cristal pode ser entendida como um recurso inevitável à construção do ambiente imersivo, já que se tratava de um arquiteto com propostas interdisciplinares; por outro lado, se não fossem as interações e a competente criação de um conjunto associativo de significantes de toda ordem midiática, o tridimensional não conteria o caráter imersivo conceitual que detém. ${ }^{60}$

As construções das imagens, no tocante à manipulação, são surpreendentemente bem feitas. A estratégia de misturar imagens citadas com imagens manipuladas se apresentou como a condição sine qua non à formação de imagens reticulares. Neste caso, temos um feliz encontro entre a exploração tridimensional de um espaço e as opções sígnico-multidimensionais. A derrocada da imagem como ilustração do conceito científico começa a se estabelecer, justamente a partir do momento em que delegamos à imagem uma sintaxe própria, cujo limiar estamos vivenciando nos ambientes hipermidiáticos. ${ }^{61}$ Como vi- 


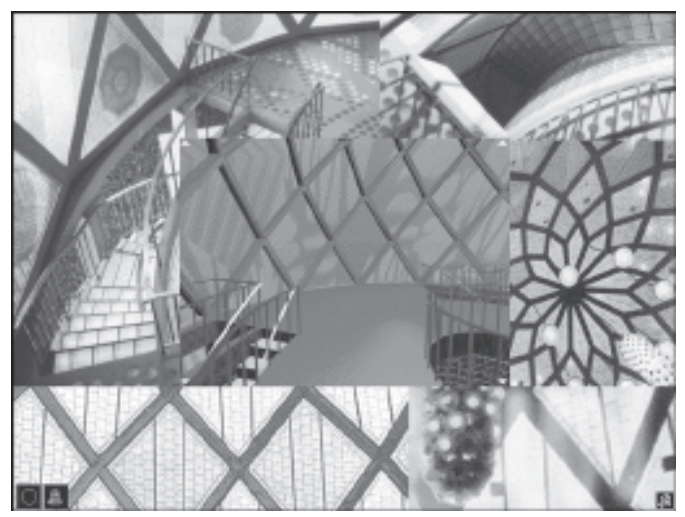

mos, as cores e as formas, no caso de Bruno Taut, são os elementos da materialidade, são as opções que transmitem, inclusive, um compromisso ético-estético com o conceito de construção arquitetônica. Neste sentido, Arthur Engelbert, coordenador desta obra digital, resolve criar ambientes em 3D que, por um lado, talvez fossem impossíveis como a expressividade arquitetônica em questão, mas, por outro, trazem consigo, justamente a partir deste impossível construtivo, a grande possibilidade de demonstração dos conceitos. Corredores de cristais coloridos, que formam inúmeros jogos geométricos e misturam as visões do abandono da perspectiva e do sentido único nos espaços de uma construção, são apresentados em ambientes que questionam profundamente a possi-



bilidade de representação da obra arquitetônica, fazendo com que o agente da navegação não saiba mais se está habitando um ambiente tridimensional ou uma pintura ou, até mesmo, uma poesia topológica. ${ }^{62}$ Insisto nesta trajetória conceitual presente na construção de obras digitais, porque procuro revelar a existência de um universo sígnico que se define como opções teóricas. Matrizes híbridas que nada explicam porque muito pretendem demonstrar ${ }^{63}$; demonstrando, nada concluem, porque pretendem manter a abertura à leitura dos agentes que imergem nos ambientes; quando no interior dos ambientes, os agentes devem procurar interagir de várias formas, não necessariamente intervindo ou modificando o ambiente, mas, sobretudo, desenvolvendo reinterpretações das idéias que lhe são apresentadas durante toda imersão.

Destaco aqui um princípio fundamental que pode ser apresentado como a interatividade como conceito. Os grandes exemplos da complexidade do jogar, sempre os encontramos na arte, sobretudo, na arte contemporânea em suas versões em instalações (arte e tecnologia). No entanto, acredito que não podemos aprofundar estas questões, sem que antes alteremos radicalmente as premissas científicas diante das abordagens

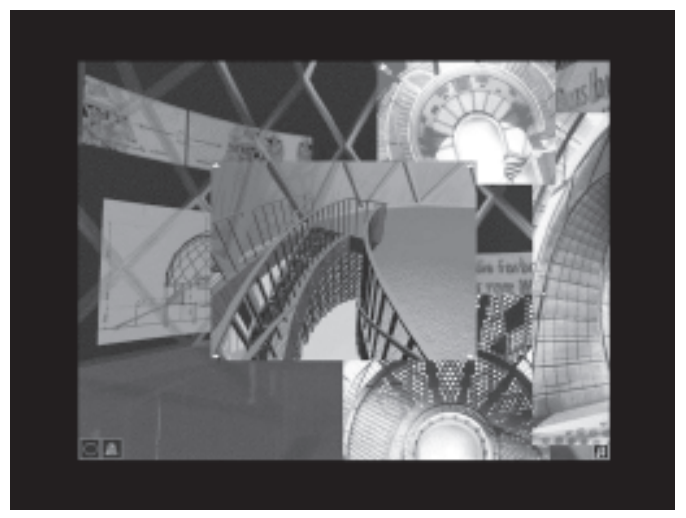


estéticas. ${ }^{64} \mathrm{O}$ grande desafio que nos impulsiona neste momento diz respeito ao princípio de que as estruturas complexas da criação e da programação devem ser pesquisadas no interior da própria complexidade, presente na compreensão que se apresenta como entorno. Ou seja, isso é proporcional a afirmar que, não havendo analiticidade no tratamento temático do conhecimento científico, não pode haver complexidade na relação das soluções de programação com a expressividade hipermidiática conceitual. ${ }^{65}$ Podemos encontrar mais uma manifestação destas inter-relações complexas na opção geométrico-triangular do menu, quando é acionado um terceiro nível interativo. Neste nível, encontramos um conjunto de 12 imagens que, individualmente, contêm uma nota musical acionada a cada vez que o cursor passa sobre cada imagem. Se passarmos o cursor rapidamente sobre as imagens, as notas são acionadas concomitantemente e produzem texturas musicais, cuja seqüência melódica quase nunca se repete, nem na mesma navegação e muito menos levando em conta a diversidade das navegações possíveis entre vários agentes interagindo no ambiente. Temos aqui, novamente, uma relação espacial entre poesia, música, arquitetura, conteúdo acadêmico e

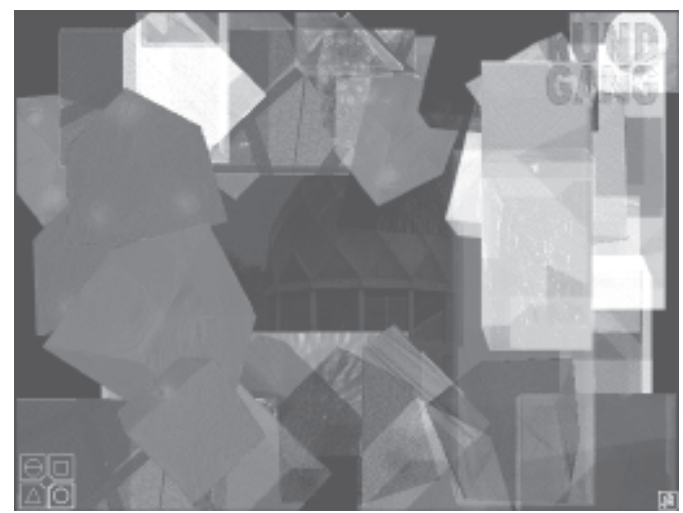

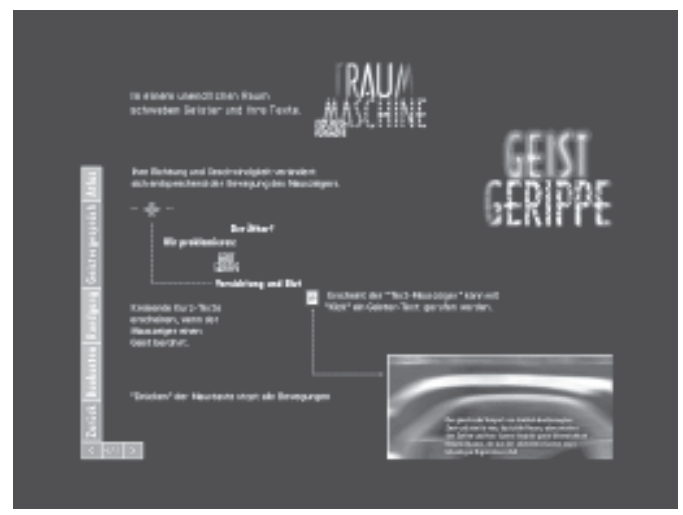

imagens reticulares, pois as notas que se presentificam nas doze imagens remetem à estrutura dodecafônica de Schönberg. ${ }^{66} \mathrm{O}$ trabalho digital sobre Bruno Taut nos oferece, neste momento, uma ligação entre seus conceitos de arquitetura e o atonalismo de Schönberg, no qual se procura uma definição de série como matriz composicional a partir de uma seqüência de doze tons cromáticos sem repetição. Neste movimento musical, como na arquitetura de Taut, nenhuma manifestação pode ter procedência sobre outra, ou seja, não há centro na composição, seja sonora, espacial, cromática ou temporal.

A partir do menu que apresenta doze imagens como ícones, podemos acessar um grande conjunto de temas como: estruturas da transparência, relações entre cristal e água, entre água e perspectiva, entre serialismo e arquitetura, entre a pintura de Kandinski e espacialidade, entre cores e materialidade, entre figuras geométricas e tridimensionalidade, entre primitivismo e essencialidade etc. As relações são ativadas, e textos e imagens começam a compor formas como um grande puzzle sendo construído sem que objetivasse a definição de uma imagem final. A partir do momento em que paramos de navegar, uma síntese 


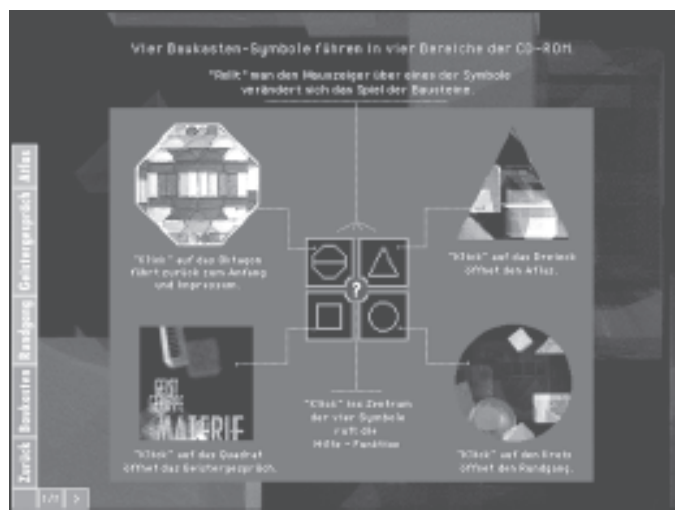

de nossas passagens é apresentada na tela, como uma sintaxe imagética como representamen da própria compreensão.

Temos ainda a apresentação de uma cartografia que indica a relação entre os conceitos básicos e as opções de criação. Os esquemas cartográficos apresentados pelos autores são extremamente significativos sob o ponto de vista de demonstrarem as opções metodológicas presentes no processo de pesquisa e criação. Acredito que o amadurecimento da utilização dos recursos digitais, como estratégia de pesquisa e de produção de ambientes, necessita profundamente de uma análise meta-teórica para que variáveis e funções possam ser discutidas e, até mesmo, avaliadas, no meio acadêmico. Talvez pudéssemos fazer um paralelo, mal com-

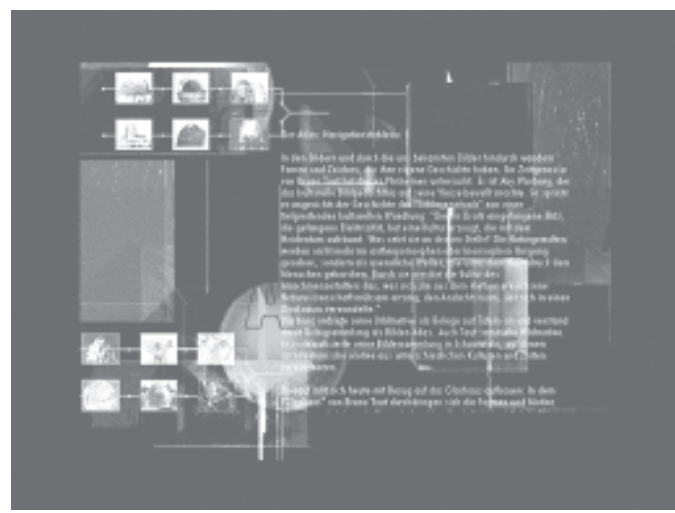

parando, entre estas cartografias e as referências bibliográficas e os esquemas explicativos ou grafismos que desenvolvemos em meio às dissertações e teses. Nas cartografias de Bauen im licht, temos uma estrutura de navegação pensada especialmente para a demonstração das opções de criação e programação. É interessante notarmos como esquemas de navegação podem apontar para um caminho de análise das obras em hipermídia, já que uma das grandes barreiras, ainda hoje existentes para que possamos defender nossas idéias pesquisando-as e expressando-as digitalmente, está no fato de não termos critérios de como avaliar determinadas obras. Nesta obra, por exemplo, podemos experimentar as questões que, quando estão postas com os recursos escritos, raramente passam de descrições e de caracterizações textuais. Já nessa obra digital Bauen im licht, quando são tratados os seguintes temas: a posição antimodernista de combater a concepção purista de fachadas brancas, por meio da denúncia da ausência da cor na arquitetura; a concepção de reformar um determinado contexto urbano em suas circunvizinhanças, que não havia renovado a visão de paisagens urbanas a partir de um profundo diálogo cromático como uma posição ético-estética; a relação entre arquitetura e poesia sonora, declarando e praticando o princípio de Hans Poelzig de que a arquitetura é música silenciosa; ou a concepção de que a arquitetura deve expandir a utilização de sua pele, não num sentido de exterioridade, mas de proteção, interioridade e expansividade; são todas estas concepções trabalhadas na hipermídia como interatividades que tiveram que enfrentar o desafio do encontro entre programação e criação. 
Neste momento, no Brasil, aparece o trabalho Valetes in slowmotion. ${ }^{67} \mathrm{O}$ argumento desta obra buscou analisar, demonstrando, as noções de tempo e espaço no universo prisional brasileiro. Valetes se refere à expressão corrente na gíria prisional, dormir de valetes, e slow motion vem de uma noção de tempo presente na própria linguagem videográfica. O trabalho em CD-ROM reserva uma característica muito interessante, pois surgiu posteriormente à pesquisa e à produção de um vídeo (com influências teóricas socioantropológicas), portanto, mais uma vez, estamos diante de um trabalho que dependeu totalmente de uma conseqüente reflexão analítico-teórica. $O$ encontro entre argumento e construção do entorno é explicitado com muita propriedade, por possibilitar a manifestação interativa de temáticas com olhar socioantropológico: o cotidiano da sociabilidade na prisão; a junção das dispersões temporais com as tentativas da unicidade manifestada pela ordem estabelecida; o controle do tempo, sempre vital, e a observação dos movimentos físicos; o ato de jogar com a circulação de objetos e pessoas como uma construção formal, como se a organização do espaço e do tempo fosse a grande premissa à transformação das consciências; e a ação circular de signos de temporalidade como controle e descontrole dos espa-

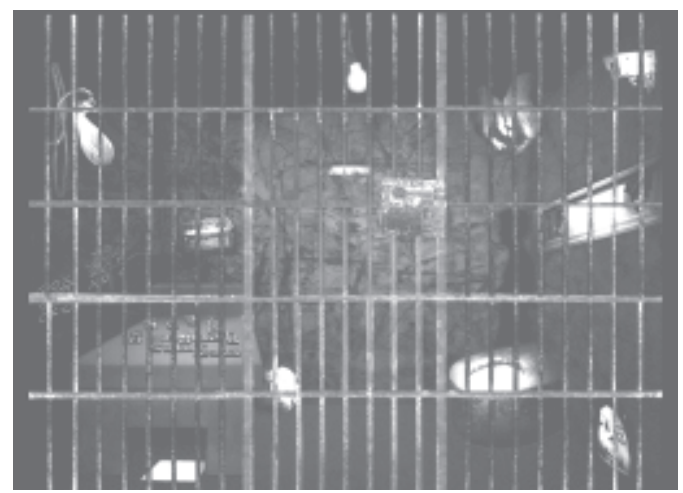



ços por temporalidades diversas e do tempo pela diversidade espacial. ${ }^{68} \mathrm{~A}$ opção do entorno está materializada na imagem reticular-manipulada de uma cela repleta de imagens/montagem de objetos e fotografias.

A própria tela de acesso apresenta inúmeras metáforas teóricas: os objetos estão presos, mas podem ser acessados, o conjunto de imagens, como a exposição de faces, o vaso sanitário, o jogo de dominó, a bola de futebol, a luz e a janela, são túneis, passagens para outros lugares que, concomitantemente, saem e não saem da cela. As grades manifestam um distanciamento do agente navegante, mas o cursor permite ativá-las. Há uma sombra à direita, logo atrás do vaso sanitário, que se revela como se fosse uma marca de identidade do uso do es-

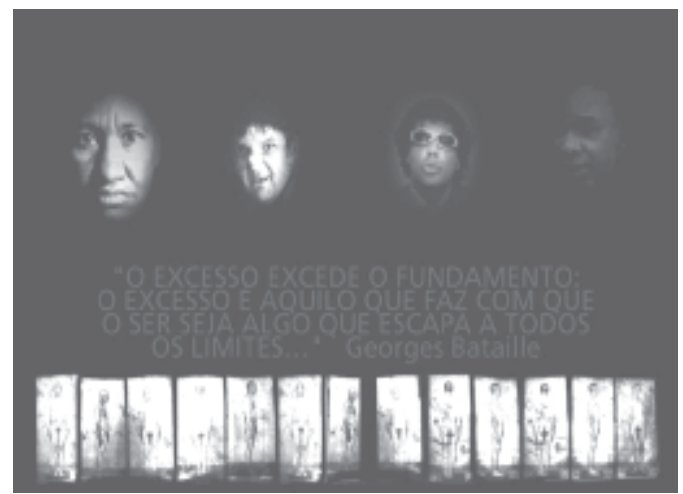


paço, assim como as mãos deixam registros nas grades em função de uma temporalidade da observação para o exterior, um estar fora sem sair, um estar lá sem deixar de estar fora. A ambientação oferecida pelo entorno, logo na tela principal, já inaugura um chamamento para que nos sintamos imersos no ambiente da prisão. O tempo que passamos navegando nesta obra digital pode oferecer a experiência interativa de olharmos para o mundo do interior da cela. Pode-se dizer que esta é a principal premissa deste trabalho, desde a introdução que já ocorre com uma montagem de vídeo em meio a um depoimento de um preso, inaugurando o acesso à obra digital: o ladrão quando não tem o que fazer morde até o dedo para ver o sangue cair. No entanto, dificilmente os resultados da construção deste entorno seriam tão conseqüentes se não fosse o trabalho de formação de bancos de áudio. ${ }^{69}$ Este é formado por depoimentos de presos, ruídos reverberados de portas batendo, fechando, passos distantes e efeitos de guitarras com distorções metálicas. Há, portanto, aqui um lugar para visitarmos por meio de uma caminhada repleta de regras que se manifestam em imagens, sonoridades e, sobretudo, programações. A construção deste ambiente digital, assim como no caso de Bauen im

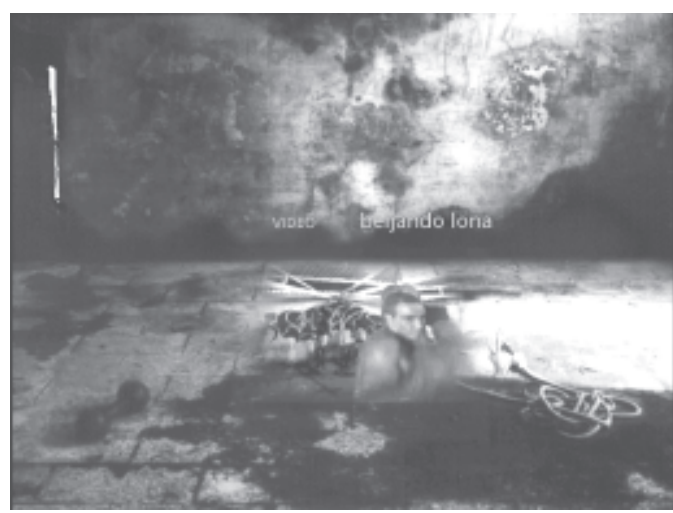

licht, só se tornou possível em função do encontro entre reflexão teórica e a produção de grandes bancos multimidiáticos. A existência de somente um destes fatores não tornaria possível todo processo analítico presente na obra digital. Deste modo, temos presente um importante conjunto de estratégias metodológico-teóricas como indicadores de uma produção científica em hipermídia: o argumento está presente com muita propriedade nas opções da construção do entorno, contando com a colaboração de imagens reticulares, de um áudio em efeitos de transição, rotatividades sígnicas e cacos muito bem construídos. Ao que tudo indica, foram cuidados conceituais presentes desde o início da pesquisa, ainda em vídeo. ${ }^{70}$

Existem associações e relações desde a primeira tela, que invocam um grande número de conceitos teóricos em concomitância. Ativando a opção no rosto exposto na tela principal, encontramos depoimentos cotidianos de presos e internos de sanatórios. Neste ambiente, fotografias remetem a estudos de anatomia humana, personagens são ativadas à medida que clicamos sobre elas e textos aparecem tanto como citação de filósofos quanto como depoimentos de presos. A criação de uma tela totalmente escura e os depoimentos em vídeo, a partir de fachos de iluminação sobre os rostos, reforçam significantes que transmitem imersão, luz de interrogatório, vigília, abandono, isolamento, dentre outros. A diversidade dos depoimentos, junto da diversidade de rostos em meio a toda esta criação, expressa características imagéticas e sonoras impossíveis de serem descritas numa escrita científica, inclusive pelo fato de os depoimentos se transformarem em co-autoria. Alguns destes depoimentos ratificam o universo ilocucionário presente na hipermídia, já que são apresen- 
tadas apenas as reações faciais das pessoas, o que nos faz entender que o que elas têm para demonstrar, a partir de suas expressões, é muito mais do que poderiam falar. Neste ambiente, ainda temos uma mescla de temas que imbricam conceitos de saúde mental com o ambiente prisional.

É importante realçar que esta obra saiu acompanhada de um livro homônimo, em que podemos ter contato com a íntegra do trabalho escrito.

Outra opção a que temos acesso, a partir da tela principal, é o vaso sanitário, que acessa a tereza, nome que os presos dão à corda que usam para fugir, fabricada com lençóis amarrados. Neste ambiente, o cursor se transforma num foco de luz, com o qual podemos explorar o lugar onde contém um muro e um vaso sanitário. Um click no mouse ativa o vídeo Tereza cuja produção foi a grande responsável pela roteirização da obra digital. O tema da exploração dos espaços pela luz é recorrente e um dos recursos de programação mais utilizado na obra. No alto da tela, à direita, uma série de textos com frases dos próprios presos oferece uma relação entre valores cotidianos e a idéia de fuga.

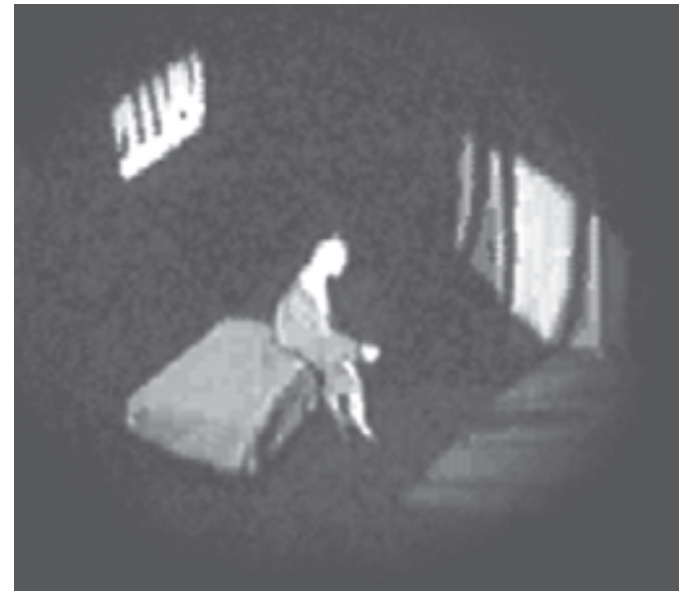

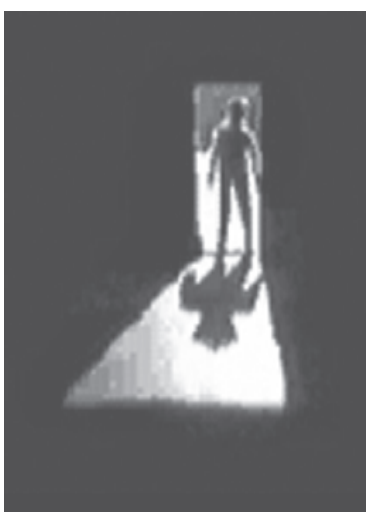

A busca de caminhos alternativos e o muro como uma barreira intransponível são temas abordados como epistemes da circularidade significante presente na obra digital. ${ }^{71}$

Outro aspecto interessantíssimo desta obra, encontramos no conjunto de transições (passagens) do primeiro para o segundo nível de interatividade. Temos um conjunto de pequenas animações com desenhos de figuras humanas sentadas, portas batendo ou espaços de salas vazias. Estas transições (passagens) ocorrem junto de áudios na categoria de efeitos de transição, portas de ferro, coisas batendo, passos descompassados, trechos de falas dos presos etc.. O encontro destes áudios com as animações possibilita transições extremamente importantes para a obra digital. Trabalhar conceitualmente as transições é algo que temos que analisar como importantes possibilidades à ativação do diálogo entre os mais variados ambientes. ${ }^{72}$ No caso de Valetes, as transições são uma espécie de deixar em suspenso o ambiente do qual saímos e introduzir o ambiente para o qual nos dirigimos. Também se presentificam como passagens que abordam o tempo e o espaço, como ênfase da ação cronotópica de cada imagem de cada visão ou de cada som do ambiente interativo. $O$ cotidiano na cadeia 


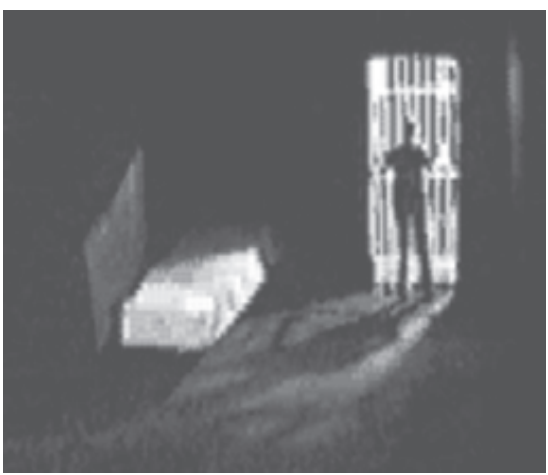

é percebido aos fragmentos, em retalhos de sonoridades e de imagens. Há presença do randomismo nestas transições, característica que já anuncia um poderoso caminho reinterpretativo com relação ao conceito de autoria.

Outra opção a partir da tela principal é uma janela. Deste lugar, acessamos uma tela composta de uma porta com uma pequena abertura, onde o movimento do cursor mexe com uma construção de imagens manipuladas (foto/montagem da prisão). O movimento do cursor como imagem emula um olhar de dentro da cela e ativa uma estrutura de áudio, composta de colagens de efeitos e de gravações de depoimentos. Num determinado lugar da imagem, que deve ser descoberto pelo agente navegante da

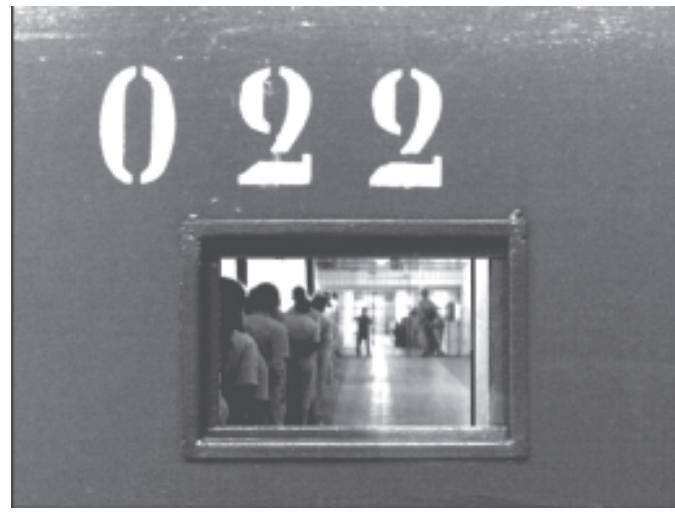

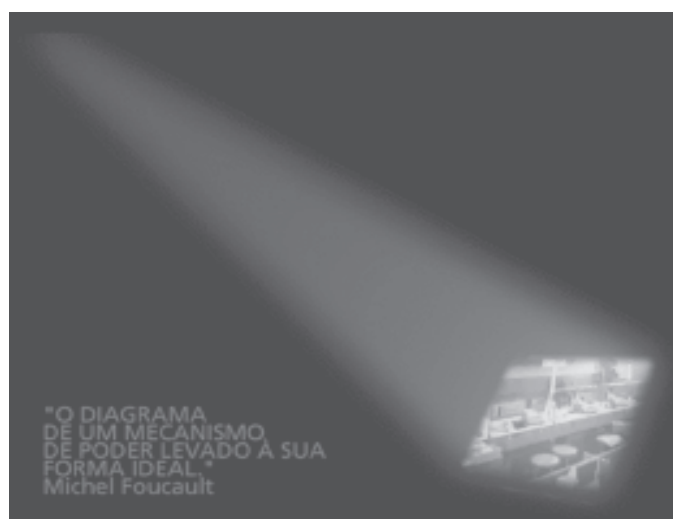

hipermídia, encontramos um vídeo com o depoimento de um dos presos mais conhecidos (o Zorro) da história do sistema carcerário brasileiro. Portanto, os cenários construídos para os ambientes têm uma responsabilidade recíproca em toda obra: promovem um questionamento sobre as condições de possibilidade de construção da identidade no ambiente da prisão, por um lado, e, por outro, oferecem um grande questionamento a respeito da realidade prisional, como um ambiente de sobrevivência no interior de um dos mais rigorosos sistemas de controle social do Brasil. Os olhares dos presos bem como suas estratégias espaciais e temporais estão, em grande parte, expressos nesta obra digital.

Noutra opção da primeira tela, caímos num cenário de jogo de dominó. As peças estão dispostas segundo a regra do jogo, mas em cada metade de peça encontramos um vídeo-clipe do grupo de Rap Racionais, cujo tema principal é o cotidiano dos presos. Num dos clipes, o massacre de 1992 no presídio paulistano Carandiru é comparado com o holocausto, e cenas se constroem, novamente, dentro e fora da regra do jogo. O caminho do cursor neste ambiente oferece a ação de ativar e desativar vídeos, escondidos e montados de acordo com a posição 


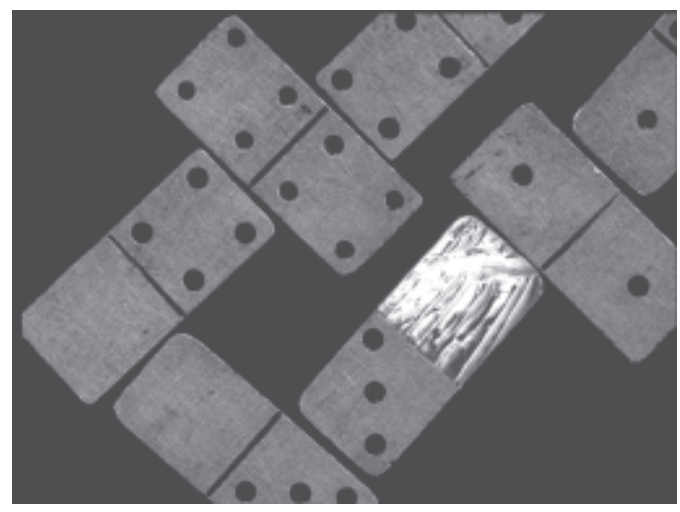

das peças. Importante, também, é realçar que as peças do jogo de dominó que vemos na tela são de ferro e foram feitas pelos próprios presos. Esta é outra característica muito bem explorada nesta obra digital. Todos os ambientes, basicamente montados a partir de fotografias, contêm as marcas do uso, do tempo e das condições possíveis de higiene na prisão. ${ }^{73}$ As paredes, o chão das salas, os objetos portáteis, as mesas, cadeiras e até mesmo o sistema elétrico da prisão têm uma existência marcada pelo tempo, sobretudo a partir da noção de usabilidade e de desgaste material.

Uma das interações mais interessantes que pode ser acessada a partir da tela principal é o panóptico. Novamente o cursor se transforma em foco de luz que ativa vídeos de assaltos a estabelecimentos comerciais. A marca da vigília tem sua existência estabelecida desde o contexto social até a sociedade prisional.

Enquanto a interatividade acontece à direita da tela, frases de filósofos como Michel Foucault ( $A$ visibilidade é uma armadilha) ou Gilles Deleuze (A prisão diz respeito ao visível, é um regime de luz antes de ser uma figura de pedra) vão marcando presença à esquerda.${ }^{74}$ Noutra opção determinada como

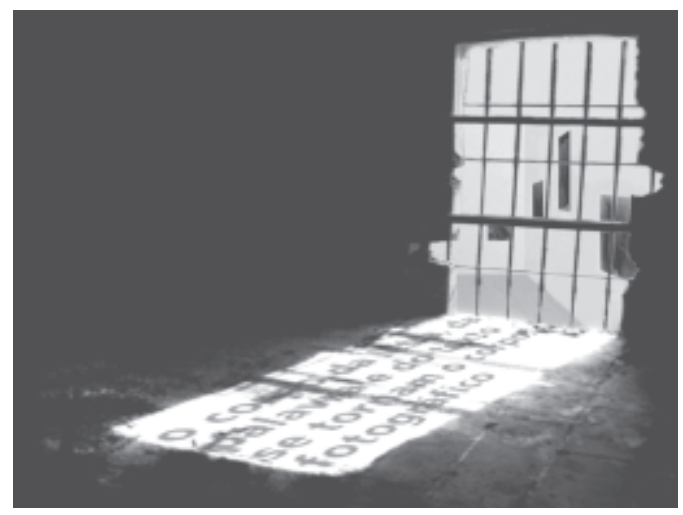

tensão, temos as imagens de uma televisão, de uma janela com grades, de objetos cortantes e de uma máquina de escrever. O conjunto destas imagens, todas em tom vermeIho, fica pulsando para reforçar o significante tensão. Cada imagem ativa um vídeo de reportagem jornalística sobre momentos de rebeliões nas prisões, e o destaque acontece para a rebelião de 1992, no presídio Carandiru, quando 111 presos foram assassinados. Este momento nos lembra que todas as interações cotidianas no sistema prisional fazem referência à sociedade como um todo, buscando explorar a impossibilidade de uma análise dos fenômenos como objetos "isolados". Nestes momentos, conseguimos vivenciar melhor as grandes relações, por exemplo, entre um objeto cortante e a historicidade envolvida nos eventos prisionais. Reforça igualmente a noção de responsabilidade da sociedade com todas as ações humanas decorrentes tanto de acertos da legislação, quanto com as conseqüências das injustiças da lei. ${ }^{75}$

$\mathrm{Na}$ opção jogo da velha, entramos num ambiente de cela, um trabalho de imagem montagem, que se define como background para vídeos, que trazem à cela espasmos de resistência aos limites que o 




espaço físico impõe ao corpo e que este impõe à consciência. ${ }^{76}$

Na janela gradeada, a sombra de uma pessoa fica passando de tempos em tempos, ratificando o conceito de vigília. Os vídeos entram sob a textura da parede, pele sobre a pele, conceito sobre conceito, um encontro conseqüente em opacidades frágeis. $O$ áudio mescla gritos, com guitarras e cacos de batidas de metais.

Outra opção interessante a partir da primeira tela é a que dá acesso ao vídeo Beijando a lona. O ambiente também mescla vídeos com as texturas das paredes e, além do vídeo Beijando a lona, apresenta vários vídeos históricos sobre sistemas carcerários brasileiros. O boxe é tratado como uma maneira de exercitar a disciplina, o cumprimento das normas, o respeito e nas palavras de um preso (novamente temos uma relação do entorno da cadeia com os representantes da sociedade): “...os guardas querem te submeter a uma disciplina que eles não têm". Neste ambiente, a ocorrência de vídeos de abordagem histórica, junto da imagem de um cenário repleto de marcas de temporalidades e de falta de cuidados, acrescenta uma característica diacrônica às abor- dagens sobre a temporalidade na prisão, como se este espaço social detivesse, em função de suas condições históricas, uma temporalidade paralela, uma continuidade afundada na repetição de signos espaciais que, por um lado, insistem em se atualizar, mas que, por outro, não deixam de ser o mesmo. Nesta obra digital, existem ambientes interativos a partir de trabalhos como o de Nuno Ramos que foram apresentados na Bienal de Arte de São Paulo (1996). A instalação artística aborda a relação entre temporalidade e luz e foi montada com grandes lâmpadas derretidas unidas por grossos cabos de eletricidade. ${ }^{77}$

A profundidade da relação das soluções de programação com a expressividade hipermidiática conceitual alcança, na obra Valetes, níveis importantes à investigação que proponho aqui. Além das conseqüentes relações entre imagens manipuladas e reticulares, áudio, textos de citações, vídeos como texturas e um entorno bem resolvido, temos a presença de alguns elementos de programação que bem representam os caminhos que podemos explorar como linguagem científica. Um dos recursos que muito contém da complexidade temática é a limitação de tempo relacionada ao movimento do cursor quando estamos

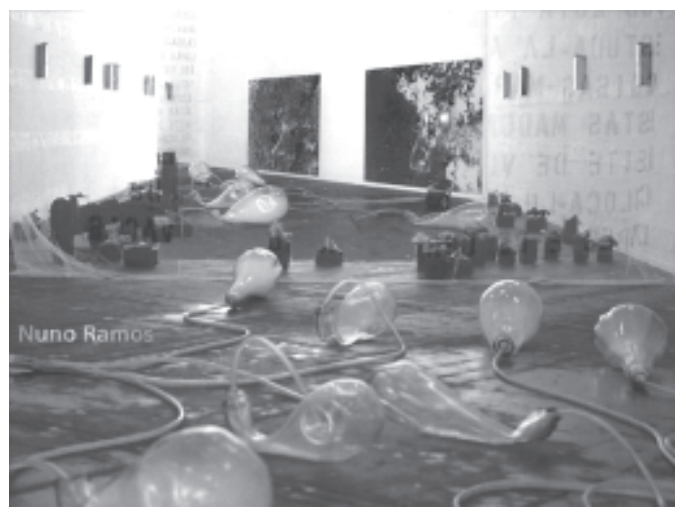


navegando por qualquer lugar desta obra digital. Definido por recursos da programação de autoria, caso deixemos o cursor sem movimento por alguns segundos, toca uma sirene junto da ocorrência de vozes e ruídos metálicos dispersos. Neste momento, somos jogados para qualquer lugar do entorno. Ou seja, vivenciamos uma experiência de que, neste ambiente, o tempo não nos pertence, pois estamos imersos em regras e normas que limitam a relação entre temporalidade e espacialidade. Caso não seguirmos as regras, somos penalizados. Apesar de este recurso tecnicamente conter uma relativa simplicidade de programação, adquire uma dimensão poderossíssima graças ao fato de o entorno conceitual ter sido criado e produzido com muita informação e competência. Em meio a estes acontecimentos, frases de presos (em locuções) ocorrem em movimentos circulares de ida e volta, reforçando os significantes mais assumidamente explícitos: "A gente vale na cadeia o que tem (...)"; "sabendo que ele vai matar eu, matei ele (...)"; "aí aconteceu que eu ia cortar todo o meu corpo (...)"; "na cadeia tem vários tipos de ladrão (...)". Notemos que os conceitos teóricos estão sendo pensados e repensados desde os momentos de concepção das imagens, dos vídeos e do áudio. No entanto, o momento mor da análise está localizado na hora de programar, pois, caso não existam condições técnicas de realização dos conceitos, como interatividade, igualmente não teremos condições de experimentar as opções teóricas dos autores. ${ }^{78} \mathrm{O}$ conceito de entorno que estamos propondo não acontece mais como "ambiente", simplesmente, mas como um mundo a ser criado, que tem sua existência possibilitada nos interstícios da programação. Aqui habita a nova linguagem, que, não sendo mais vídeo, escrita, ou produção de áudio numa estrutura linear, acontece como a oferta de um novo acontecimento sígnico, caracterizado principalmente pelas condições híbridas e hipermidiáticas das quais ainda estamos no limiar de seu desenvolvimento. Mas o salto que propomos neste momento não representa simplesmente o domínio de recursos tecnológico-digitais ou, menos ainda, a exploração estéticovanguardista que movimentos artísticos sempre investigaram. O salto está localizado na apropriação destes recursos como investigação, como caminho possível ao desenvolvimento do conhecimento científico, seguindo as possibilidades abertas pela expansão do império da escrita de tradição metodológico-científica. ${ }^{79}$ Por esse motivo é que escolhemos criações na área acadêmica, que não se simularam de pensamento no seio de instituições artísticas, mas, sim, obras que procuraram explorar, prioritariamente, um desdobramento estético, institucionalmente muito mais característico da arte do que da ciência, sem que abandonassem por completo as relações com os compromissos metodológico-científicos presentes nos prérequisitos básicos dos sistemas de pós-graduação stricto sensu.

Neste momento é prudente explorarmos a idéia, em nível institucional, da relação entre produção do pensamento científico e expressividade artística na contemporaneidade. ${ }^{80} \mathrm{Em}$ não havendo uma renovação das instituições responsáveis pela linguagem científica, não conseguiremos promover uma aproximação mais conseqüente com produções artísticas no contexto acadêmico. O problema básico destas barreiras está no fato de que, enquanto isto não for aprofundado, o diálogo promotor de um novo contexto metodológico, com novos critérios científicos de avaliação não terá espaço institucional. Valetes é um excelente traba- 
Iho para promover esta discussão, pois reúne as tradições da poesia videográfica, da poesia oral, das artes plásticas, das artes gráficas, da construção de áudio não linear e da programação de autoria a serviço da construção de ambientes estéticos. Outro fator com muita importância aqui é a manifestação do papel do autor no contexto das tecnologias digitais. Não que defenda com unhas e dentes os privilégios do monopólio da autoria no tocante aos conceitos pressupostos, mas, sim, que a investigação que vise pesquisar tais critérios depende, em grande escala, de um redimensionamento do conceito de autoria no contexto da produção do conhecimento científico. ${ }^{81}$

Não é o conceito de arte que precisa ser revisto, mas o de experiência estética. A definição de estética como antítese de racionalidade científica, que se estrutura como filosofia a partir do século XVIII, necessita de um redimensionamento no sentido de enfrentar as premissas que indicam que todo o diverso da escrita metodológicocientífica atual deve ser entendido como uma expressividade estética no domínio da irracionalidade. ${ }^{82} \mathrm{Se}$, conceitualmente, é bem verdade que isto não tem mais sentido no âmbito filosófico-teórico, institucionalmente não podemos cair na hipocrisia de achar que arte e ciência se equivalem. Portanto, entendo por experiência estética a vivência como jogo que se apresenta como manifestação de conceitos e posições teóricas, e se expressa a partir da criação de associações entre as ações dos agentes produtores de linguagem e os interesses do conjunto da comunidade científica. Noutro momento, será necessário resgatar as discussões das relações entre ética e estética, mas agora no âmbito da produção do conhecimento científico. Para isso, temos que reconstituir tanto o conceito de experiência quanto o de estética no contexto das discussões sobre hipermídia e produção do conhecimento científico. A experiência na interatividade deve apresentar uma pertença de sentido que não está somente relacionada a um aspecto particular, mas adota e transmite um conjunto de sentidos que se apresenta diante da navegação. ${ }^{83} \mathrm{O}$ que é proporcional a dizer que toda experiência estética é uma experiência inacabada e, sobretudo, inacabável com o sentido, ainda que teórico. ${ }^{84}$ Seu sentido torna-se infinito porque representa um todo palinódico e não a unidade de um processo aberto. Podemos ter então, na margem digital, uma reabilitação da significação sígnica dos sentidos científicos. Na modernidade institucional dos novecentos, a compreensão da arte trilhou um caminho de oposição à realidade prática; de aparência, a arte passa a ser entendida como processo, e, à ciência, cabe o poder mais conseqüente de compreender a realidade. A grande guinada da modernidade ocorre a partir da passagem de uma formação e educação pela estética à educação para a estética. Na tradição da tecnicidade científica, o campo da estética transformou-se num mero ver ou ouvir. A estética transformou-se em forma incompatível com o conceito de juízo lógico. No interior da margem digital, quiçá, seja possível a inversão deste processo. ${ }^{85}$ Neste caminho, a essência da estética não é uma atualização transitória que manifesta uma pura consciência histórica, mas a manifestação de um ser que se atualiza recorrendo historicamente a si mesmo. Esta condição pode estar aberta num ambiente de hipermídia. Estas são algumas questões que trabalhos como Valetes nos fazem refletir e que aprofundaremos noutro momento. 
O momento que nomeei de demonstração de estruturas estéticas hipermidiáticas aprofunda (e, até certa medida, inaugura), a partir de uma orientação conceitual, as relações com a programação de autoria. Este momento expressa um período de conclusão em relação à associação entre divulgação do conhecimento científico e hipermídia. Vimos, porém, que estes trabalhos já inauguravam alguns ensaios da relação entre investigação e hipermídia. A diferença básica refere-se à ênfase que devemos fazer, a partir deste momento, no conceito de investigação, como demonstraram Valetes e Bauen im licht. Por um lado, investigar um determinado tema a partir da sistematização bibliográfica, a fim de construir um texto metodológico-científico, é uma estratégia que se situa, fundamentalmente, nas estruturas metodológicas do verbal escrito; por outro lado, investigar um tema, desde o início, em suas inter-relações híbridas (entre as matrizes visual, sonoro e verbal), bem como produzir ambientes híbridos a partir desta investigação, indica a possibilidade de exploração de universos sígnicos que provavelmente não seriam abordados se ficássemos somente no desenvolvimento verbal formalizado da escrita científica.

\section{Investigação analítica em versão hipermidiática}

Podemos dizer que o uso estético das tecnologias digitais, quando presente desde os primeiros momentos de uma investigação científica, indica passos decididamente revolucionários à metodologia dos trabalhos científicos. As obras digitais que surgem a partir do ano 2000 reforçam este caminho. $\mathrm{Na}$ verdade, o que temos aqui, por um lado, é uma taxionomia mais definida de obras digitais, pois ou propõem radicalizar as rela-

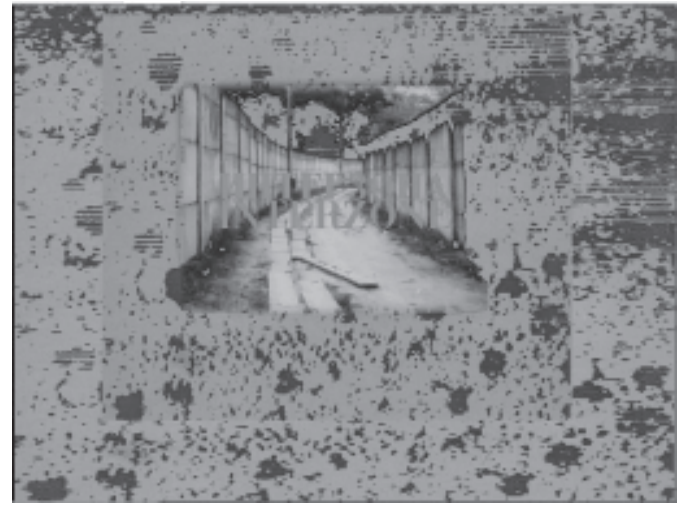

ções entre investigação, tecnologia digital e divulgação do conhecimento, ou assumem uma característica enciclopedista e apontam às investigações mais aprofundadas de trabalho coletivo, ou, numa orientação mais radical no sentido operacional, apresentam-se como grandes estruturas de bancos de textos e/ou imagens, vídeos e/ou áudio. Apesar de todos estes objetivos serem importantes à especulação das questões que venho propondo, gostaria de dar ênfase àquelas que enfrentam a investigação como algo hipermidiático por excelência. Este período podemos nomear de investigação analítica em versões hipermidiáticas; nele, os pesquisadores se revelam, primordialmente, programadores e criadores de ambientes interativos, e é nele também que ficam evidentes as competências interdisciplinares e multimidiáticas como competências a serem alcançadas individual e coletivamente.

Neste momento, tivemos o lançamento da obra digital Interzone, coordenada por Franz John, ${ }^{86}$ que apresentava como argumento discutir de forma interativa temas sociofilosóficos referentes à área "vazia" que existia no meio do muro de Berlim. As soluções apresentadas previram um agente extremamente interativo no interior deste am- 


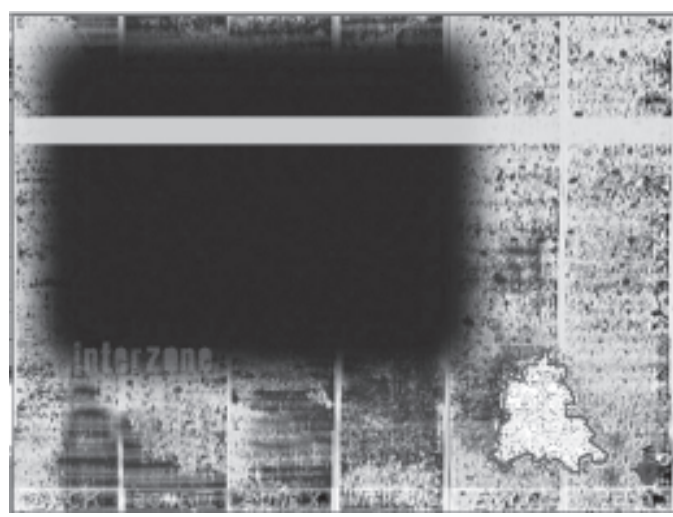

biente. Esta obra digital já nasceu em meio às reflexões hipermidiáticas. ${ }^{87}$

O entorno é o próprio muro. O muro aparece em fotos, vídeos, desenhos e em estruturas 3D. Portanto, desde o início, a produção de um banco multimidiático foi fundamental para este trabalho, e podemos notar que em todas as etapas já se vislumbrava a hipermídia que seria construída. Os elementos que vão sendo constituídos ao longo da navegação no muro são basicamente sonoros e videográficos, e agem no sentido de nos provocar, impelindo-nos a interagir com os eventos. A interzone, região interna ao muro, teria sido um espaço Zeitloss, um espaço perdido do tempo, no qual encontraríamos um naco preservado de algo da identidade alemã. A tela de acesso a esse traba-

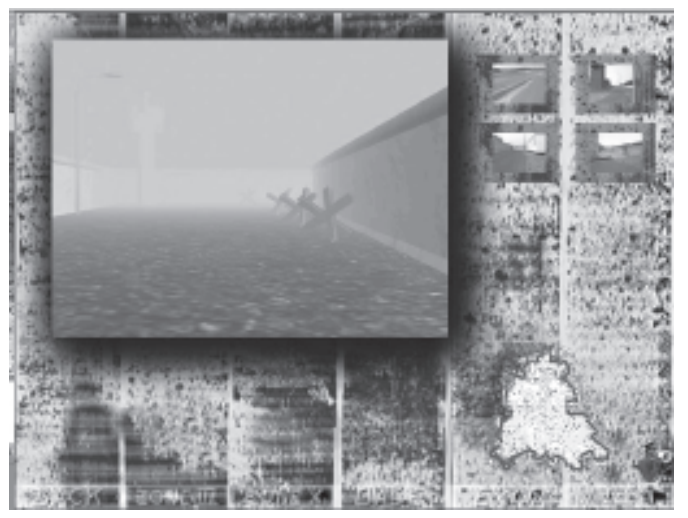

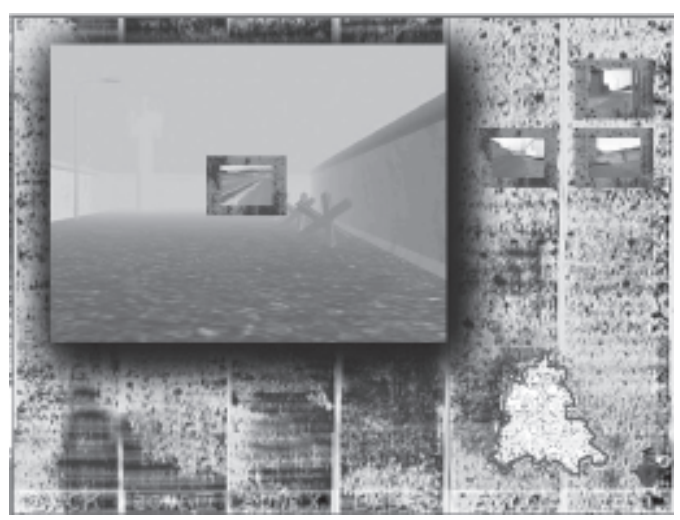

Iho apresenta as opções de zone III, zone $X$ e Interzone. A bem da verdade, as três zonas são três maneiras diferenciadas de se navegar pelos mesmos bancos de imagens, textos, vídeos e áudios. À medida que vamos navegando pela Interzone, um mapa do próprio muro vai demarcando a navegação e se constituindo numa espécie de guia. ${ }^{88} \mathrm{O}$ ambiente se estabelece como um jogo, no qual as regras básicas estão suficientemente claras para que seja possível jogar, mas, também, estão suficientemente escondidas para que seja possível se surpreender. Este movimento concomitante, e é importante que seja assim, do mostrar e esconder característico do jogo, demonstra a essência interativa desta obra digital. ${ }^{89}$ Dificilmente um ambiente teria esta potencialidade tão marcada, como o entorno definido pelo mundo interno ao muro. Mundo imaginário, que melhor expressa o Outro como linguagem e que, ao mesmo tempo, se define como o lugar do vazio da inconsciência como manifestação do jogo cultural-ideológico. A exploração, neste interior, não deixa de ser um estado de consciência que procura jogar com a interatividade como se estivesse desenvolvendo uma sintaxe imagética. Podemos afirmar aqui que a pluralidade retida nos ambientes tridimensionais tem um universo de características que é impossível de ser descri- 
to e só é passível de ser entendido quando estivermos imersos. ${ }^{90}$ Nestes lugares, o conceito de experiência é oferecido ao extremo, pois não se trata de uma experiência individual, mas, sim, do habitar o Outro familiar, fundamentalmente, pelo estranhamento. Existem vários movimentos e estágios neste tipo de navegação. Primeiro, há um elemento de passividade na navegação, pois cruzamos com ambientes sem que estejamos à procura deles. Segundo, de repente, colocamo-nos à busca de algo como viajantes. Terceiro, vamos à direção de algo para experimentar e constatar os acontecimentos sob várias condições. Quarto, a interferência nas coisas do mundo, mas neste momento já antecipamos regras e ações em função das experiências anteriores. Interzone demonstra estes quatro momentos em ação concomitante e nos oferece a experiência em suas condições multimidiáticas, fazendo com que nenhum vídeo, texto, animação ou áudio ocorra como mera individualidade. É interessante notar como as estruturas de programação precisam criar uma inter-relação entre os acontecimentos midiáticos e as possibilidades sígnicas de compreensão.

Quando estamos na opção do menu Interzone e ocorre a navegação numa estrutura tridimensional da parte interna do muro, são destacados pontos da navegação que ativam um menu de vídeos. Caso selecionemos um destes frames e o arrastemos para o interior da animação tridimensional, o vídeo que apresenta tal espaço será ativado no interior da animação oferecendo uma movimentação circular de frames. A repetição do mesmo ocorre, concomitantemente, como se o tempo se apresentasse passível de congelamento e uma existência paralela de vídeo e estrutura 3D pudesse "representálo". Há, portanto, neste trabalho, o anúncio das possíveis relações analíticas entre vídeo e construção de ambientes tridimensionais. ${ }^{91}$ Quando ocorre uma proposta conseqüente de entorno, não estamos mais diante de uma simples aplicação de recursos tecnológicos midiático-digitais, mas diante da fundação de novas sintaxes, comparável com a ocorrência de metáforas em obras analíticas nas humanas. ${ }^{92}$ Trata-se de uma renovação metodológica que necessita ser investigada, sobretudo em seu jogo de estranhamento e familiaridade. $O$ conjunto de signos apresentado nos vídeos deste ambiente está associado aos momentos em que a navegação em 3D estaciona. Assim, é possível investigarmos as localidades internas ao muro, a partir de uma orientação conduzida por uma animação em 3D; esta condição indica a inauguração da descaracterização entre o que é autêntico e o que é inautêntico. Surge a idéia, por exemplo, de que o vídeo não pode ser considerado uma referência ao simbólico mais conseqüente do que a animação em 3D. Não cabe mais, neste momento, a ação de qualquer critério de referencialidade a uma realidade. Efeitos computacionais são tão potentes e reais quanto a fotografia ou o vídeo. Para pensarmos diferente, teríamos que acreditar num universo sígnico que fosse predominantemente indiciário e fora da

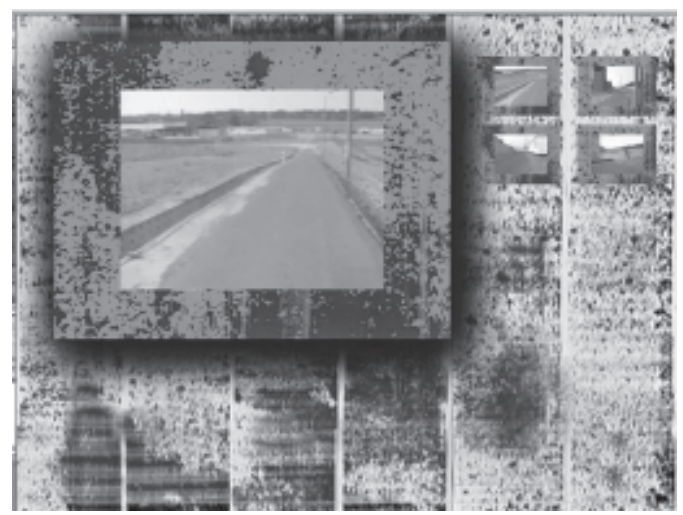


temporalidade, mas sabemos que isso é impossível. No entanto, as expressividades do vídeo já foram estudadas ao longo da segunda metade do século $X X,{ }^{93}$ mas as manifestações dos jogos simbólicos do tridimensional como vídeo ainda estão num estágio de experimentação e de escolaridade básica. Se, por um lado, esta lide ainda se encontra num estágio conceitual básico, por outro, o ato de modelar em 3D já pode ser avaliado, nesta obra digital, como uma criação conceitual dirigida por Franz John. ${ }^{94} \mathrm{~A}$ ação de modelagem tridimensional do muro de Berlim, enfatizando a Interzone, adquire uma condição investigativa já durante a sua própria construção e, por outro lado, os conceitos artísticos e/ou sociológicos, incutidos nestes momentos, acabam sofrendo transformações causadas pela ação da modelagem em 3D, já que se trata de um ambiente tão repleto de signos e de historicidades quanto o muro. ${ }^{95} \mathrm{O}$ interessante, neste caso, é que o muro tem seu elemento simbólico 3D constituído não através de uma complexa obra arquitetural, mas, sim, a partir do simples erguimento de duas colunas de parede que respeitam as curvas e dobras da planta.

Interzone é um ótimo exemplo da condição de habitação que teórico-metodologicamente necessitamos criar para que o processo de imersão ocorra. A imersão depende de uma familiaridade criada não entre conceitos e "simulacros", mas entre a construção de habitações que acolherão determinados eventos interativos e a predisposição para jogar. Esta predisposição não pode ser imposta, da mesma forma que a imposição da leitura de um texto científico em nada garante a fundação de uma compreensão. O 3D, como ambiente, localiza-se como um processo conceitual de modelagem e renderização de imagens de síntese que ob- jetiva proporcionar a fundação da predisposição ao ato de jogar. Quando cuidadosamente (no meio acadêmico, entenda-se conceitualmente) construídos, estes momentos tridimensionais fundantes do jogar possibilitam a existência concomitante e contraditória, (manifesta e no jogar geralmente pelo estranhamento) de uma sensação de infinitas possibilidades e de freqüentes desvelamentos da finitude dos conceitos. Nestes movimentos de deslocamento significante, não temos uma grande diminuição dos espaços para reações contemplativas (característica primordial do vídeo), pois, buscando o rigor da expressão, somos lançados ao interior de um entorno do qual, ou saímos e abandonamos a navegação, ou nos entregamos às suas regras, tal como numa ação cotidiana. Neste movimento de sermos lançados, encontramos o jogo da impossibilidade de condições meta-interpretativas. É fundamental, portanto, que não nos posicionemos como quem observa um observador nos observando, pois precisamos agir buscando as coisas que estão neste mundo e, para isso, é importante que nos mantenhamos abertos à procura, à pergunta e, sobretudo, ao estranhamento. Sob o meu ponto de vista, estas características sempre ocorreram em meio aos procedimentos de de-

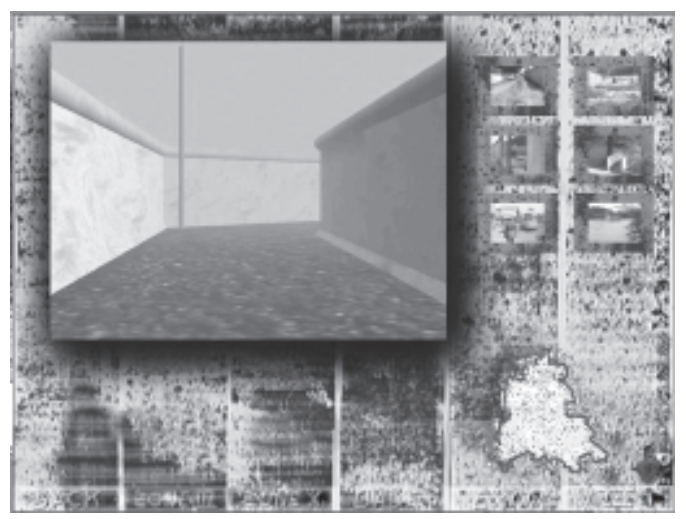


senvolvimento do conhecimento científico, mas nunca foram valorizadas por ele. Ao contrário, sempre expressaram uma condição inversa do que representaram na arte, ou seja, ameaçam qualquer concepção "evolucionista" da ciência. Isto é proporcional a dizer que, diante da escrita metodológica, tanto a modelagem quanto a criação de ambientes tridimensionais aparecem como anomalias, como mutações que ameaçam os rigores da lógica da cientificidade. ${ }^{96}$

Outra característica muito interessante deste trabalho está na utilização não-linear dos vídeos que compõem o entorno. A opção Zone III ativa uma tela na qual três estruturas videográficas aparecem concomitantemente. As possibilidades de sincronização dos três vídeos alteram os eventos dos próprios vídeos e de seus respectivos áudios. Os frames são contados, um por um, demonstrando que qualquer noção temporal é, sempre, uma metáfora, um hipoícone, ou seja, a construção de um conceito de temporalidade que está subordinada à impossibilidade de descrever o tempo tal qual alguma coisa. ${ }^{97} \mathrm{O}$ presente nunca se presentifica tanto quanto os signos nunca se pretrificam em sentidos. Como a linguagem, o tempo é algo que não se controla. Nesta tela, não temos o conceito de que a ocorrência histórica ocorre em algum lugar ou num determinado tempo, mas, sim, a concepção de que o espaço do jogar, onde sou lançado e no qual preciso agir (fazer coisas), ocorre de maneira temporal-espacial. O espaço e o tempo não podem ser entendidos como estruturas vazias, no sentido de serem mensuráveis quantitativamente por princípio. O tempo que levo para chegar de um lugar a outro, é "medido" com maior eficiência pelo cachimbo que estou fumando do que pela quantificação matemática. Portanto, esta re-

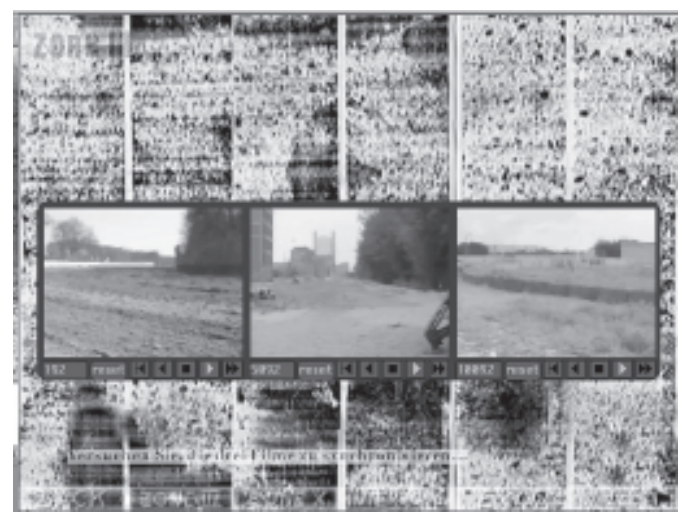

lação espaço-temporal não pode ser interpretada somente a partir das condições subjetivas de uma noção de sujeito, mas somente pela soma dos acontecimentos, em que as condições subjetivas são apenas mais um fenômeno que estará ali interferindo. Na ação da temporalidade, abro espaços e só inauguro temporalidades porque abro espaços. Só estou imerso neste mundo se tenho uma postura fundadora na ação do jogar-no-tempo-espaço. A relação entre as soluções de programação e a expressividade hipermidiática conceitual explora as condições espaço-temporais dos próprios ambientes, como um conjunto de eventos de programação, que persegue a complexidade das compreensões teóricas de um lugar que se convencionou chamar "muro de Berlim". Portanto, os questionamentos espaço-temporais estão alojados no interior do muro, assim como as condições para que Teseu saísse do Labirinto só puderam ser criadas e compreendidas a partir do momento de ele estar no seu interior. ${ }^{98}$

A opção Zone $X$ explora de outra forma a estrutura do muro. Desta vez, estamos do lado de fora. Estejamos onde estivermos. Aqui o jogo nos impele para que movimentemos e escolhamos um lugar para imergir. 
Apesar de parecer apenas mais um menu de acesso às interações, Zone $X$ apresenta as possibilidades de jogar com o próprio conceito de Interzone manipulando os espaços "de fora". Aqui temos a possibilidade de visualizar o trajeto que Franz John percorreu com suas câmeras de vídeo e fotográfica, ainda durante o ano de 1990, na tentativa de um registro imaginário do "intocável". Os 180 quilômetros carregavam 30 anos de temporalidade fronteiriça, num encontro que é demonstrado por citações do cineasta russo Andrei Tarkovski e do escritor americano William S. Burroughs. Uma característica muito relevante, trata-se do que também encontramos na obra digital Valetes: a ocorrência de vídeos mesclados com a própria textura das paredes. As paredes são o corpo de toda textura que fala. Este procedimento de trabalhar e mesclar as opacidades das imagens, no caso desta obra, adquire uma expressividade profundamente conceitual à medida que o muro demonstra uma historicidade viva em suas entranhas. Cachorros e objetos de toda ordem também fazem parte deste mundo de paralelas de concreto e interferem na navegação toda vez que ativamos os extremos do muro. Há imagens citadas, manipuladas e reticulares. As imagens citadas são compostas por cartazes de aviso, por sinalizações e pequenas referências icônicas. O predomínio nos ambientes é das imagens manipuladas, que são deslocamentos e montagens de fragmentos do mundo do muro. A complexidade da montagem presente nas imagens manipuladas é o fator que possibilita a existência das imagens reticulares. ${ }^{99}$

Há, nesta reticularidade, a intenção de construir os sentidos a partir da falta constitutiva de uma exterioridade. As condições de construirmos sentido para as coisas que nos cercam são dependentes dos freqüentes estranhamentos para os quais necessitamos estar abertos. Na opção Zona $X$, o giro do ambiente expressa a circularidade de sentidos que ocorre no jogo da presença e da ausência.

O áudio nesta obra detém uma significação especial, pois trabalha com cacos e efeitos de transição recolhidos dos próprios vídeos produzidos durante o ano de 1990. Existem colagens de áudio que procuram acompanhar as colagens das imagens. Alguns cacos são pequenas colagens retiradas de filmes de Tarkovski, outros, citações de ruídos de vento, coisas caindo no chão e conversas a distância.

Nesta mesma época, foi lançado no Brasil a obra digital Hipermídia, psicanálise e história da cultura. ${ }^{100}$ Neste trabalho, procuramos enfrentar o desafio de um ambiente digital que possibilitasse expressar o encontro entre estas três grandes áreas do pensamento. $\mathrm{O}$ argumento foi definido pelo processo transdisciplinar possível a partir da manifestação e do jogo de trinta conceitos. Jogo, inconsciente, techne, oralidade, significante, incompletude, cultura material, fragmentos, hipermídia, verdade, universo do discurso, psicologia/história, ilocucionário, não-

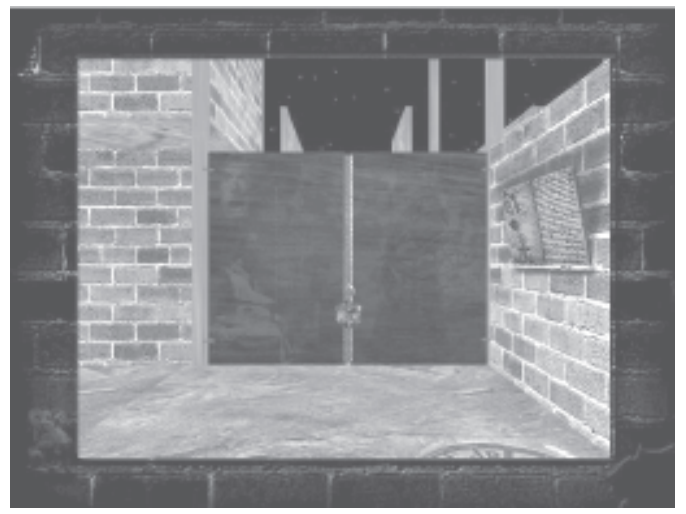


dito, lexia, cultura, alteridade, linearidade, fundamento, fenômeno, hermenêutica, horizonte, espelho, demonstração, linguagem ordinária, espelho, ciência, desejo, sujeito e topologia foram os conceitos escolhidos como interfaces teóricas entre hipermídia, psicanálise lacaniana e história da cultura (realçando as abordagens interdisciplinares da história das mentalidades). O entorno é um labirinto. A concepção do labirinto foi escolhida por estar presente tanto nas concepções psicanalíticas como na definição da relação entre identidade e alteridade. ${ }^{101} \mathrm{O}$ trabalho contou com uma sistematização de mais de mil imagens, criação de áudio, animações e programação como etapas que foram criadas e processadas, concomitantemente a uma inter-relação conceitual como direcionamento das interações.

O entorno não é uma tela, mas uma estrada, um caminho. Logo na entrada, podemos encontrar um livro exposto na parede que contém uma apresentação da obra digital. Nesta apresentação, procuramos trabalhar com o procedimento de imagens manipuladas na página ao lado de cada texto. Os textos podem ser lidos ou vistos num todo junto com as imagens. Colagem imagética e texto são uma coisa só. O nome do texto da apresentação de Lúcia Santaella, A trama estética da textura conceitual, já exprime a condição de urdidura de todos os eventos dispostos no interior do labirinto, e o conceito de textura conceitual contém a essência do trabalho criativo com o superlativo processo de montagem que uma obra dessas exige. Como diz Santaella, "as estruturas da hipermídia constituem-se em arquiteturas líquidas". ${ }^{102}$ Há, nesta obra, a presença de um trabalho criativo que envolve diretamente as estruturas de modelagem 3D, com os trabaIhos de montagem de imagens, este com a renderização em 3D, com a produção de áudio e, sobretudo, com as opções de variáveis e funções na sintaxe programática. Este processo pretendeu garantir potencialidade reticular às colagens. Trabalho aqui com a hipótese de que a construção de imagens reticulares está condicionada à complexidade dos momentos anteriores, tanto de formação dos bancos multimidiáticos, quanto a relação destes com as estratégias conceituais das montagens.

Quando, na navegação, irrompe um objeto tridimensional, já temos ali um processo múltiplo de criações. A imagem da vaca com uma figura topológica de um toro no pescoço, por exemplo, tem sua textura relacionada com o conceito de topologia, e os eventos interativos relacionados com a idéia de

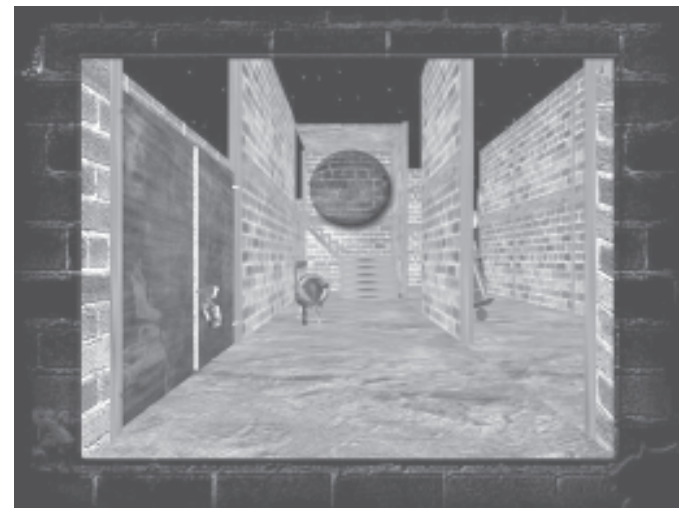


equilíbrio. $\mathrm{O}$ ato de equilibrar-se numa linha é paralelo à ação da linguagem quando, nesta, a instabilidade das possibilidades de comunicação está cercada pelo universo sígnico inconsciente que os constitui. ${ }^{103} \mathrm{~A}$ insistência em interagir com cada objeto nos lança em direção de uma seqüência de imagens manipuladas, que objetivam construir um universo imagético em torno do qual entendemos o conceito. Ao terminar o processo de construção/colagem deste universo, encontramos a possibilidade de penetrarmos no nível do hipertexto. As transições se manifestam no jogo, numa sobreposição de camadas, cujo objetivo é demonstrar que a sintaxe hipermidiática de definição conceitual não pode ocorrer pela escrita teóricometodológica. Para esta obra, desenvolvemos uma metodologia que foi definida a partir das opções filosófico-teóricas que se apresentaram como os fundamentos mais conseqüentes. Fenomenologia heideggeriana, psicanálise lacaniana, semiótica peirceana, hermenêutica gadameriana e a interdisciplinaridade construída pelo encontro filosófico-teórico destas regionalidades presentes na obra de alguns historiadores das mentalidades. É importante destacar que estas opções já estavam presentes no momento de criação do entorno.

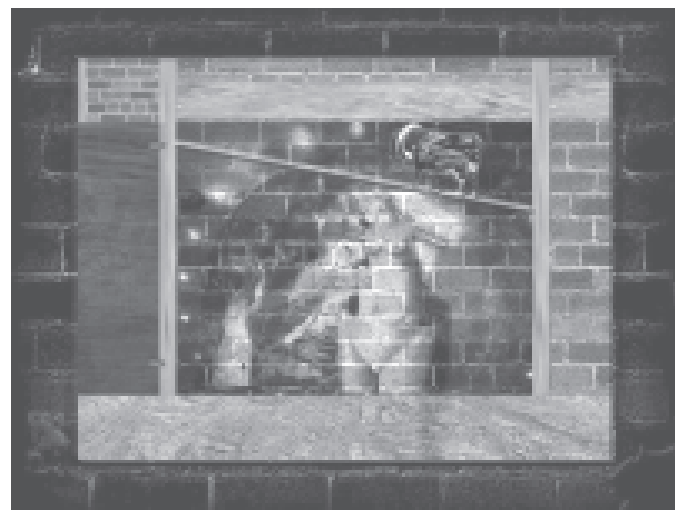

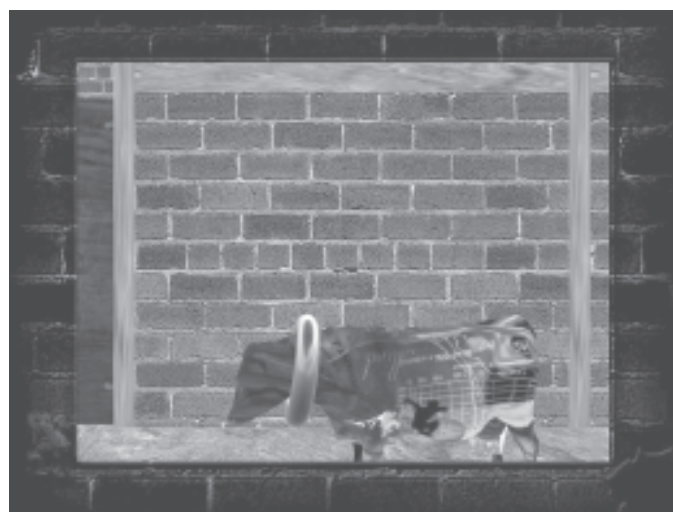

Temos, então, uma exposição reticular de eventos pré-programados: objetos 3D, que levam à transição imagética, que levam à estrutura de hipertextos. A navegação se constitui na freqüente reconstrução de caminhos alternativos, mas, no entanto, a estrutura física do labirinto é mantida igual. O labirinto, considerado como a manifestação dos jogos da linguagem, contém tanto condições sígnicas freqüentes quanto estados de alternância do que poderíamos chamar de demonstrações conceituais. Importante, também, é a idéia de que os conceitos no labirinto, como nas ciências, estão topologicamente próximos, e é graças a esta proximidade que eles conseguem criar sua identidade teórica. ${ }^{104}$ Assim, um papiro que contém camadas de tijolos e figuras arqueológicas está próximo do conceito de inconsciente e do ambiente que abarca as colunas coríntio que são referências ao conceito de ruínas e fragmentos de Jacob Buckhardt. O áudio de cada ambiente contém frases, conceitos, cacos e efeitos que estão inclusos na circularidade sígnica, tanto das estruturas construtivas quanto da conjuntura hipertextual que pode ser acessada a partir das paredes do ambiente. O áudio só se define pelas imagens reticulares e pela programação, sendo aprofundado analiticamente 
cada vez que imergimos no hipertexto. Há algo de essencial na atitude de nos colocarmos à disposição de imergir no ambiente, pois devemos emular uma temporalidade impossível, não estamos mais à mercê da temporalidade fílmica, já que os fragmentos não têm seqüencialidade. Estamos frontalmente impelidos à busca, pois já não nos é dada uma estrutura lógico-linear. A contemplação transformou-se em tática, em estratégia e em habilidade, mas não deixou de ser contemplação. ${ }^{105}$ É desta forma que entendemos a construção hipermidiática. Próximo do que Zizek nomeou de teatro histéri$\mathrm{co}$, temos que reconstruir o corpo, sem que as peças possam se encaixar. ${ }^{106} \mathrm{~A}$ imagem final é impossível, mas não importa, pois a relevância está no ato de construir caminhos e está expressa na impossibilidade de se criar um drama. A presença da possibilidade de construção dos sentidos é manifestada no jogo da ausência dos objetos. Tal como Lacan entendeu a castração como pre-condição à inserção no universo simbólico, já que a constatação da falta do falo causa um processo subjetivo de busca e de construção imaginário-simbólica. O que falta na tecnologia é o que está preso num suposto saber, e o que se apresenta como suposto saber detém a responsabilidade do pulsar

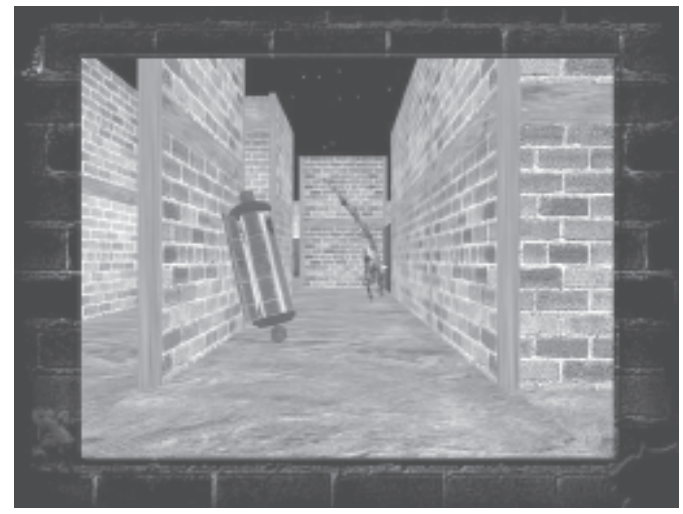

como construção da tecnologia. É assim que a tecnologia esconde em si o que nunca esperamos, uma possível irrupção do que nos redime da dimensão humana. A impotência da metalinguagem é proporcional à impossibilidade de sermos salvos pela tecnologia, pois, assim como não podemos ser instrumentos de nós mesmos, a compreensão não pode ser instrumento do desenvolvimento tecnológico. Em nossa leitura, Magritte aborda esta questão em sua obra $A$ ponte de Heráclito, propondo uma ponte interrompida em sua manifestação simbólica do jogar dialógico, mas que se apresenta inteira em seu reflexo, como se a sustentação de que toda consciência que percorre os caminhos da linguagem, se baseasse muito mais num estágio imaginário do que num estágio simbólico. ${ }^{107}$ As paredes do labirinto são falsas paredes, pois não limitam a caminhada; são passagens, ruínas de caminhos que a arte já há muito percorreu e que a filosofia e a psicanálise se apropriaram. São restos do processo de criação que ficam à mostra, para que possíveis reinterpretações as transformem, ou não, em formas de vida. Magritte é o artista mais presente no labirinto, tanto por meio de imagens citadas quanto de imagens manipuladas. ${ }^{107}$ Existem várias paredes que possibilitam o acesso a um mundo que expõe e analisa 44 telas de Magritte e suas relações possíveis com Jacques Lacan, Roland Barthes e Michel Foucault. ${ }^{108}$ É neste momento que as relações entre a programação de autoria e a criação hipermidiática começam a explicitar a soma da conjugação de todos os fatores.

Nesta obra, resolvemos traduzir Umwelt por entorno, que define toda possibilidade de imersão como uma cartografia se oferece à navegação. ${ }^{109}$ Há uma moldura cercando o labirinto e, nela, temos alguns ícones 


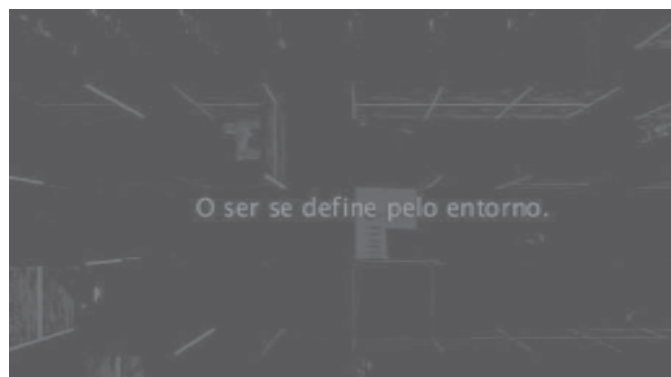

que se impõem como perpétuos. Uma imagem da fênix (imagem da coleção de Freud) reinicia a navegação, e um tijolo na parte superior à direita ativa o mapa de navegação. Sendo empurrado, o tijolo proporciona uma passagem secreta revelando um mapa do labirinto. Antes de acessarmos o mapa, aparece a máxima filosófica que diz "o ser se define pelo entorno".

O entorno é, então, explicitamente apresentado por uma grande rede composta pelos trinta conceitos. Suas respectivas disposições no labirinto são expostas por poucos segundos. Imediatamente o agente tem condições de arrastar o cursor e iluminar conceito por conceito. Um jogo da totalidade com as partes, sobretudo, o mapa demonstra, é condição essencial para qualquer criação de sentido. A combinação das partes com o todo possível emula a relação en-

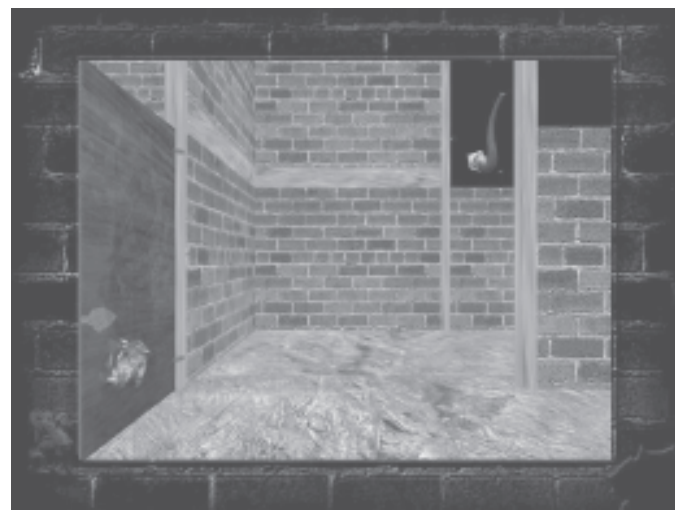

tre teoria e categorias, já que estas não podem adquirir sentido sem aquela, e, por sua vez, uma teoria só pode ser constituída a partir de um corpo conceitual analítico básico. ${ }^{110}$ Uma vez ativado o mapa, a única forma de sair dali é pela escolha de um conceito como guia para navegar. Há, aqui, a intencionalidade de explicitar tanto as localizações imediatas no interior do labirinto, quanto associações entre os conceitos e o universo imagético em torno de cada localização. O que esperamos aqui é que possamos oferecer ao agente uma versão cênica da ação conceitual, não como forma de encerrar questão, mas como tática de lidar com o conhecimento expresso em hipermídia. Portanto, o que se coloca em jogo não é mais uma "ilustração" de conceitos nem mesmo de compreensões, mas o próprio movimento da construção de sentido possibilitada pelas manifestações conceituais como formas de vida. Faz parte destas formas de vida o deslocamento significante que sempre deve nos surpreender e/ou causar estranhamento. Esta é mais uma questão importante que tantos anos de crítica de arte nos ajudaram a refletir. ${ }^{111}$ Como já disse, não pode haver compreensão sem uma freqüente irrupção de estranhamentos. Novamente, as paredes e as animações chamaram para si

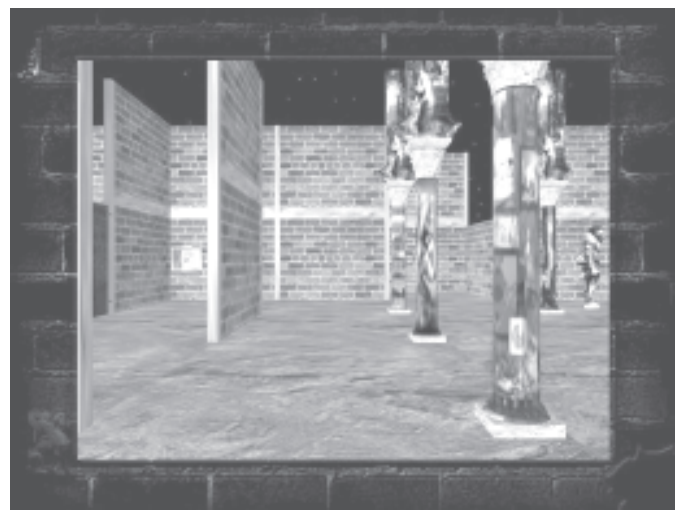


esta responsabilidade. Os sentidos e as paredes são fraturados, as animações e suas vozes são auto-referências e a repetição, como possibilidade de compreensão, está em todos os lugares. Um conhecimento que deve seguir desconhecido, uma experiência que, apesar de ser repetida, não pode ser descrita, uma demonstração que só pode ser revivida. Neste sentido, o labirinto está repleto de referências fílmicas que se manifestam como jogo, em opacidade reduzida ou a partir de exposições coladas nas paredes. As referências são citações que expandem o universo conceitual para fora do labirinto. O universo do áudio seguiu estilo semelhante, mas ao contrário de trabalhar com referências, foi criado exclusivamente para o labirinto. Pensado no contexto do conceito de jogo o áudio faz inúmeras referências à produção Myst em função de seu estilo exploratório em estrutura RPG. ${ }^{112}$ No entanto, ao contrário dos jogos que buscam a criação de um simulacro, no labirinto não temos uma intenção de semelhança com um mundo criado, mas sim a condição de emular um ambiente que se mantenha auto-referenciado.

Esta auto-referencialidade foi sintetizada nos ícones que atuaram como síntese das grandes interconexões. Todos foram animados e demonstram sua condição analítica no processo de navegação. $O$ trabalho de criação com os ícones foi intensamente discutido e planejado. ${ }^{113} A$ intenção foi testar um processo de criação de eventos que possibilitasse a passagem às transições para os hipertextos, e isso deveria ser feito pelos conceitos como manifestações ilocucionárias. Os ícones agem como se fossem personagens que pertencem a uma narrativa não-linear criando uma forma de hiperselectividade, sobretudo por oferecerem condições de acolhimento essencial às ações dos

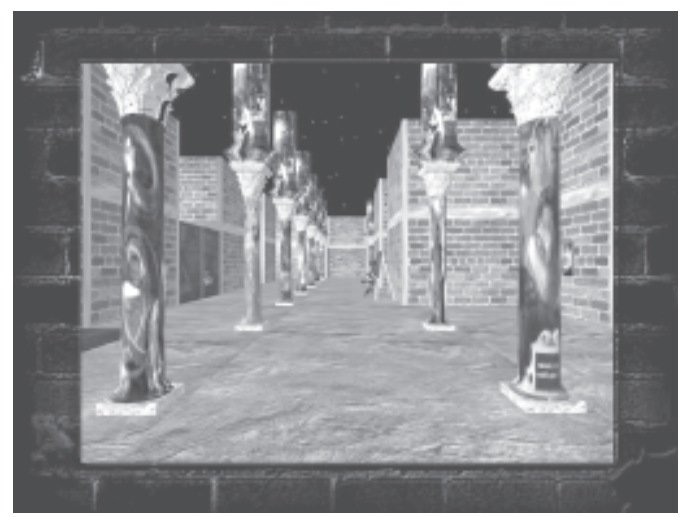

agentes interativos. O ícone de acesso ao conceito de fragmentos é composto por uma figura humana, remetendo às figuras gregas em atividades olímpicas (o lançador de disco). ${ }^{114}$ A relação com a questão clássica remete às concepções de Buckhardt e sua relação entre o conceito de ruínas e de fragmentos, no sentido de associar a condição de possibilidade de identidade cultural com as ruínas (arquitetônicas) gregas. ${ }^{115} \mathrm{O}$ conceito universo do discurso contém o ícone do conceito de significante e reforça as condições de transparência e fragmentação que irrompem em vários outros conceitos, já que universo do discurso é, em essência, um conceito de interligações. O conceito psicologia/história está expresso na imagem de uma fogueira medieval, fazendo referência a todos os temas da historiografia medieval que trabalharam com psicanálise. Esta relação é aprofundada na continuidade das interações quando a fogueira se transforma numa taça de vidro presente em algumas telas de René Magritte. Já o conceito de ciência é abordado numa animação que pulsa figuras topológicas. Ciência é um conceito tratado de forma dinâmica, sendo impossível congelá-lo numa forma só. ${ }^{116}$ As texturas dos objetos topológicos fazem referências aos conceitos de sujeito e de jogo. Portanto, 
a auto-referencialidade está também nos ícones como uma forma de conjunção conceitual, ou seja, a definição e a localização de cada um deles só podem ser conquistadas a partir da relação com outros conceitos, tal como ocorre numa teoria científica.

A idéia de explorar os primeiros momentos de contato com os conceitos de forma não-escrita na metodologia científica e, conseqüentemente, não linear, significa para nós um abandono da descrição analítica sintático-textual como momento inaugural da compreensão. ${ }^{117}$ Temos no labirinto uma convivência da linguagem metodológica textual com um universo hipermidiático que oferece caminhos que aquela não poderia oferecer; e, mesmo quando chegamos ao estágio hipertextual, não abandonamos a estrutura não-linear, graças à relação entre algumas opções de programação e o patrimônio de bancos multimidiáticos que o labirinto contém.

Ao entrarmos na estrutura hipertextual, encontramos um novo conjunto de signos que foi desenvolvido como resultado da relação entre navegação não-linear e as condições de construção de sentido a partir do contato com as páginas. Os ícones que levam à direita e à esquerda são fitas de Moebius com a torção virada para o respectivo lado. A figura topológica do toro oferece a possibilidade de registro da navegação, o espaço mor da historicidade. Por meio do toro, temos a condição de voltarmos ao espaço no qual já estivemos ou reconstruirmos toda navegação. O ícone de navegação hipertextual foi o trabalho mais complexo do hipertexto, pois além de buscar palavras como um software de hipertexto, ainda possibilita uma busca que seja resultado da relação entre dois conceitos. Caso digite na opção buscar Freud e inconsciente, o siste-

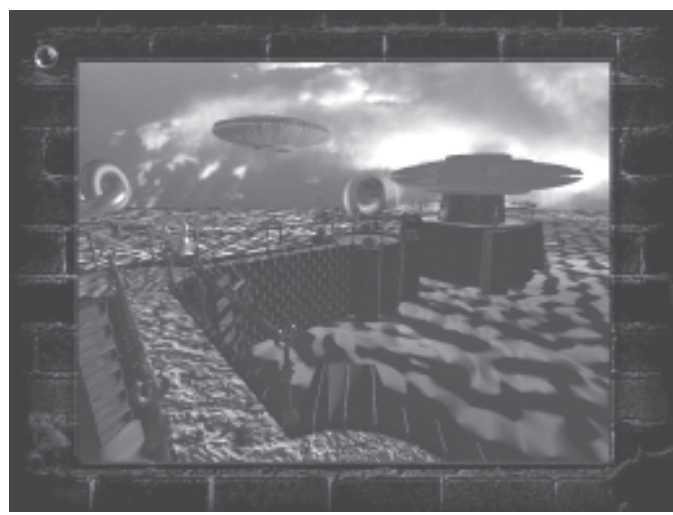

ma identifica todas as páginas em que estes dois conceitos aparecem. Mas o resultado que mais demandou trabalho de programação está não só na identificação das páginas encontradas, mas em que sentido cada conceito ocorre em cada página. Num conjunto de 1.500 páginas de textos analíticos, é fundamental que o agente tenha a opção de uma busca apurada. É interessante notar que, quando um sistema oferece uma grande complexidade de navegação, exige, por sua vez, um conhecimento analítico para que possa ser explorado. Para que esta estrutura funcionasse, tivemos que organizar página por página e escrevê-las com uma estratégia que fosse compatível com uma leitura não linear. Para tanto, os sistemas analíticos de busca foram fundamentais. ${ }^{118}$

A relação entre as soluções de programação e a expressividade hipermidiática conceitual ainda contou com a participação de ambientes "externos" ao labirinto. Nomeamos de plataforma do disco o ambiente no qual apresentamos uma análise da topologia lacaniana, na qual o toro, o cross-cap e a garrafa de klein são estudados, ponto a ponto, segundo a lógica lacaniana. Este trabalho só foi possível graças aos anos que o pesquisador Luis Carlos 


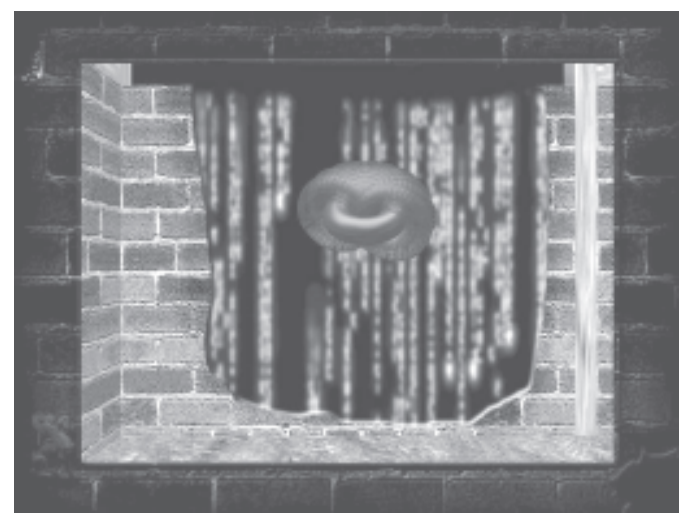

Petry dedicou à compreensão tridimensional da psicanálise lacaniana e sua topologia. ${ }^{119}$ Uma questão interessante foi a constatação, por um lado, das dificuldades de demonstração da topologia quando na bidimensionalidade do livro impresso e, por outro, a potencialidade demonstrativa da expressividade topológica, quando numa estrutura modelada e renderizada em software 3D. As entradas para o ambiente da plataforma do disco estão espalhadas pelo labirinto e buscam as localidades conceituais mais próximas, como, por exemplo, o conceito de topologia ou o de demonstração. A plataforma buscou uma associação com o surrealismo de uma forma auto-referenciada, pois o próprio labirinto é uma construção topológica. As possibilidades da navegação neste ambiente indicam cada objeto topológico como um segundo ambiente no qual podemos imergir. É o caso, por exemplo, do cross-cap que esconde uma série de pontos interativos que podem ser acessados a partir do seu interior. A plataforma do disco é mais um ambiente no qual procuramos promover o encontro entre processo criativo e opções hipermidiáticas de navegação. É interessante notar como as estruturas de navegação podem mudar suas condições sintagmáticas em função de que um ou ou- tro entorno modifica os princípios interativos. O ambiente, neste contexto, é o Outro que abarca os conceitos, algo como a ação de um universo simbólico que pode ser reconhecida, mas não conhecida, por isso é que a condição de nos perdermos em seu interior é proporcional à condição de inaugurarmos, a cada vez, nossa alteridade. ${ }^{120}$

Esta obra digital traz uma série de contribuições às possibilidades de criação de um ambiente digital teórico-conceitual: primeiro, a metodologia de criação de bancos, concomitantemente à definição do argumento e à criação do entorno; segundo, associa a criação do entorno às possibilidades de programação de autoria, possibilitando uma retomada da discussão sobre este conceito; terceiro, enfrenta o conceito de demonstração como a grande ruptura, não com o texto escrito, mas com a máxima metodológicocientífica que elege a escrita como a mídia na qual habita a verdade lógica; quarto, oferece-nos um aprofundamento do conceito de jogo (spiel), demonstrando este como o cerne dos movimentos híbridos da compreensão científica, expressa em ambientes interativos; quinto, demonstra que o conceito de incompletude, tão presente em toda historicidade regional-científica, pode estar

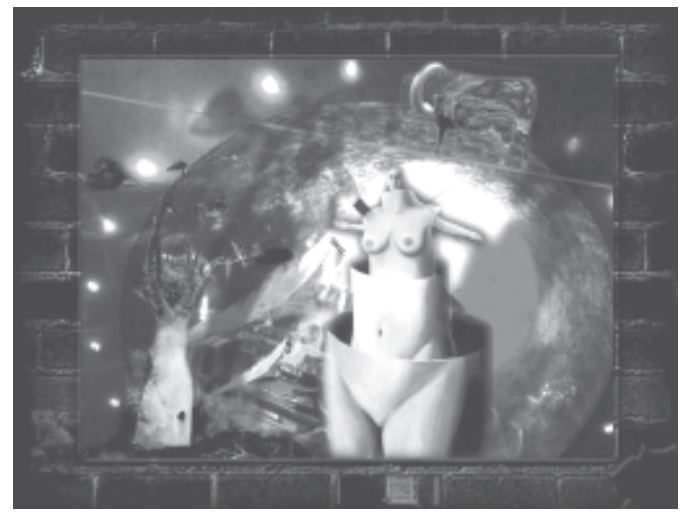


presente numa obra digital sem que necessariamente fiquemos impossibilitados de alcançarmos conclusões parciais, isto como 'autores' ou como 'agentes' na interação; sexto, defende a concepção da criação de um entorno como uma importante opção no processo de investigação, já que o entorno possibilita tanto a investigação quanto a própria imersão conceitual. Estas compreensões e tendências estão postas neste início de século, apesar de raramente encontrá-las em obras digitais.

Outra obra digital importante, neste momento, foi Potsdamer Platz que seguiu as concepções de Arnold Dietmar da Technischen Universität Berlin, ${ }^{121}$ e apresentou como argumento uma viagem transepocal nos subterrâneos de Berlim. As épocas escolhidas foram 1871-1933, 1933-1945, 1945-1989 e 1890-2001. Os períodos englobam desde a construção subterrânea das carvoeiras do final do terceiro império, passando pelo submundo da segunda guerra e da guerra fria até o momento de reunificação com o retorno da capital alemã para Berlim. Os subterrâneos de uma metrópole são invisíveis no cotidiano, mas sua presença é ao mesmo tempo sociopolítica e imaginária.



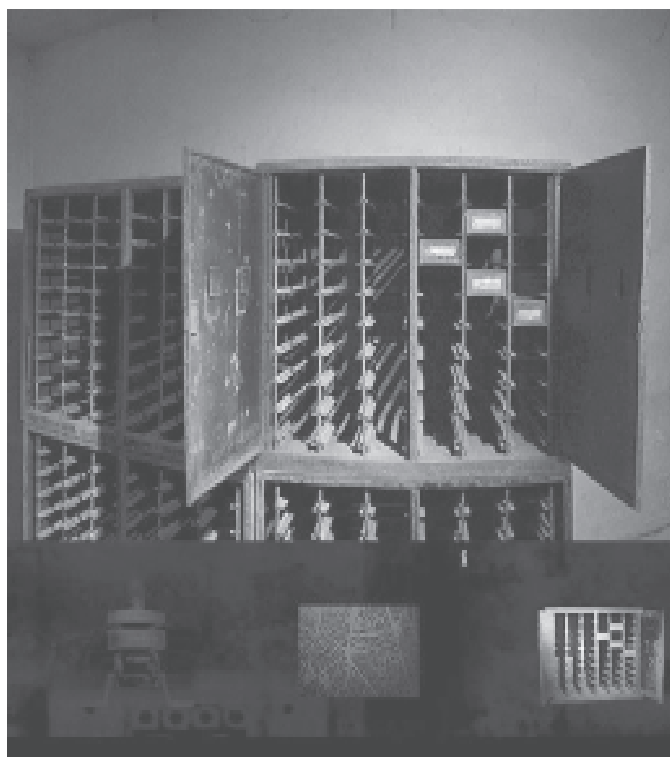

O entorno é definido por um levantamento fotográfico com o próprio subterrâneo de Potsdamer. O subterrâneo é relevado à condição metafórica de expressar uma temporalidade circular. Uma temporalidade que é manifestação do jogo, pelo caráter de manobras secretas num submundo que por muitas vezes subverteu os poderes institucionais. Estas opções da definição do entorno são propositadamente articuladas com um enorme conjunto de imagens citadas, manipuladas e reticulares. Esta obra digital demonstra, com muita propriedade, o quanto uma proposta de trabalhar com referências documentais necessita da composição de um entorno que possibilite um equilíbrio entre colagens e composições conceituais. As soluções encontradas oferecem um nível de imersão no subterrâneo, que não seria possível sem que os devidos cuidados entre programação e criação do entorno fossem planejados concomitantemente.

Ao sermos recebidos, na entrada do subterrâneo, podemos escolher entre vários caminhos: navegar pelo interior dos ambien- 


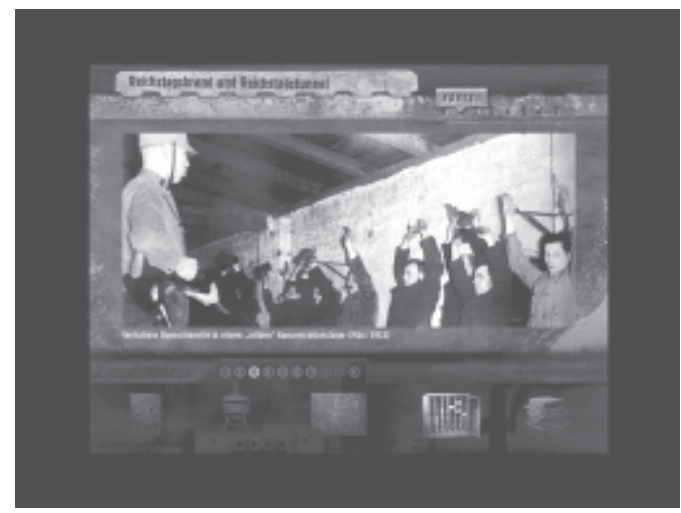

tes, explorar os objetos que aparecem já na sala de entrada ou abrir o arquivo ao fundo da sala, que contém quatro gavetas que englobam os quatro períodos históricos. A navegação pelo entorno tridimensional, composto pela reunião/colagens de imagens fotográficas, procura oferecer um conhecimento imersivo a partir dos subterrâneos de Berlim. ${ }^{122}$ Percorrendo os caminhos, encontramos uma série de objetos que autoreferenciam as soluções interepocais, que fazem parte do argumento desta obra digital. Ou seja, podemos encontrar um capacete do Segundo Império próximo a uma carta que circulou na contemporaneidade da unificação alemã. Potsdamer Platz, assim como Interzone, se propõe Zeitloss, como se o tempo estivesse perdido em função de sua existência de submundo. Os objetos foram cui-



dadosamente escolhidos em meio a um conjunto de centenas de possibilidades e assumem, nestes espaços, a condição de personagens que acabam sendo fundamentais à criação das associações com os pressupostos teóricos abordados. ${ }^{123}$ Os objetos transformam-se em signos reticulares, pois potencializam as nodosidades da navegação existente entre os mais diversos pontos do entorno. O cruzamento de épocas é um estilo de abordagem bem complexo para ser expresso num ambiente tridimensional. No entanto, está melhor solucionado na construção/colagem de objetos espalhados pelo ambiente, do que se tivesse optado por outro recurso. Noutro momento, valerá a pena aprofundarmos a reflexão sobre a importância da criação ou montagem de objetos em ambientes digitais. ${ }^{124}$ Mais que ícones, estes objetos são hipoícones, pois geralmente aparecem como fruto de um planejamento sígnico estruturado como linguagem interativa. A competência da produção hipermidiática do conhecimento científico pode ser identificada como complexa, por reunir um enorme número de novos desafios à criação. Sem dúvida que um dos principais desafios situa-se na detalhada composição analítica da relação entre o entorno e o universo de objetos que o compõem. Textura, forma, composição, tridimensionalidade e funções dos objetos são características que precisam ser pensadas teoricamente com fortes características de auto-referencialidade. Esta etapa de investigação analítica em expressividade hipermidiática apresenta o enfrentamento da sobrereferencialidade de todo o universo de produção, ou seja, no caso dos objetos, por exemplo, é fundamental que eles estejam vinculados interativamente com a programação, com os efeitos de áudio, com as estruturas tridimensionais e com seus contextos imagéticos. ${ }^{125}$ Portanto, no 




caso desta obra digital, houve uma grande importância delegada à coleta de objetos, que pudessem agrupar inúmeros conceitos que podemos definir como cronotópicos, pois agrupam temporalidades diversas no mesmo espaço. Como já foi indicado, esta estrutura está explicitada num arquivo com gavetas, expostas entre espaços abertos, insinuando a ausência de várias outras gavetas, cuja suposta presença, no futuro, pudesse aprofundar a intersecção com outras temporalidades. É interessante notar que o arquivo (como móvel) data do início do século XX e expressa a opção dos autores em manter a textura com ferrugens, resultado da intervenção do tempo. A bem da verdade, todo ambiente segue este princípio, identificando um uso a partir de inscrições, desgaste das paredes e em mecanismos mecânicos comuns de várias épocas.

Ao optarmos por uma das gavetas, temos um conjunto de narrativas e dezenas de imagens que exploram a relação entre o tempo escolhido e uma documentação da época. A idéia da gaveta como arquivo e, deste, como organização das historicidades envolvidas, oferece ao entorno uma associação entre a possibilidade de imersão e as opções teóricas que influenciaram a programação. Estas associações demonstram uma

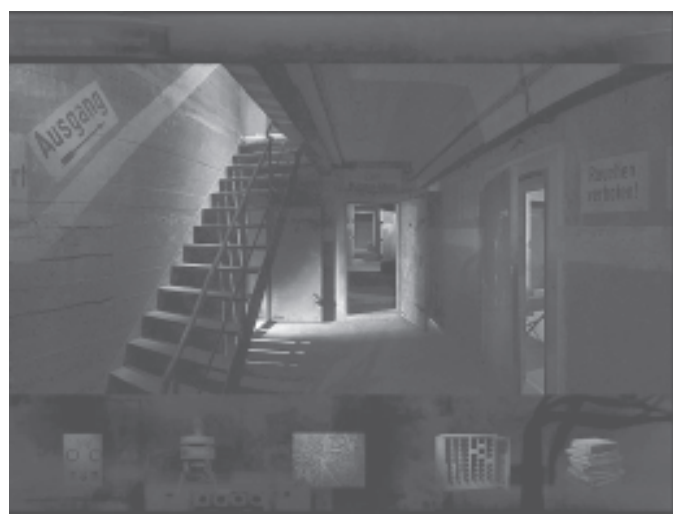

nova forma de se trabalhar com documentação científica, já que as imagens não são simplesmente ilustração de textos impressos, mas compõem um ambiente que torna os documentos parte de um mundo, emulando navegações e interações que só podem ser comparadas com a interação que temos com as coisas no cotidiano. A História do cotidiano, descrita por Agnes Heller ou Michel De Certeau, teria muito o que contribuir com estas propostas. ${ }^{126} \mathrm{~A}$ existência cotidiana é composta por uma série de pequenas buscas e interações que, por um lado, não podem estar presentes numa escrita científicoconceitual, mas que, por outro, adquirem uma vivacidade que pode ser encontrada nas interações imersivas do dia-a-dia. Contrariamente ao discurso do expert, que a partir do texto escrito descreve a iconografia, a inserção dos documentos no entorno hipermidiático guarda uma resistência maior contra o direito de falar em seu nome, pois, apesar das opções construídas que definiram sua inserção no mundo interpretativo da hipermídia, não temos neste caso um domínio absoluto como encontramos quando da descrição somente escrita de suas características, já que o usuário possui um universo maior de informações multimidiáticas para se relacionar com os preceitos da pesquisa. 
Documentários, relatórios auditivos e filmes de época também colaboram proporcionalmente à presença dos objetos, para que o rol de documentação possa cumprir o difícil desafio da composição intertemporal. Os temas trabalham estruturalmente de maneira interdisciplinar e exploram o princípio de que até $40 \%$ da cidade de Berlim estão repletos de subterrâneos. Daí o fato de chegarmos até determinados lugares e não termos condição de seguir adiante; a visualização demonstra que há mais a descobrir, mas, como não está escavado, não conseguimos prosseguir.

Apesar destes impedimentos, os lugares nos quais temos acesso representam mais de 150 anos de história da cidade e, em função da navegação tridimensional somada às opções de entorno, temos uma cidade subterrânea com suas leis, seus segredos e suas possibilidades de imersão. Os autores dizem que as catacumbas de Roma ou Paris ainda estão à espera de uma representação tridimensional como esta que Berlim ganhou. Podemos dizer que houve, neste trabalho, um conjunto enorme de possibilidades imersivas em nível de produção de conhecimento científico: a criação teórico-conceitual do entorno; a pesquisa de áudio em dezenas de arquivos e em institu-

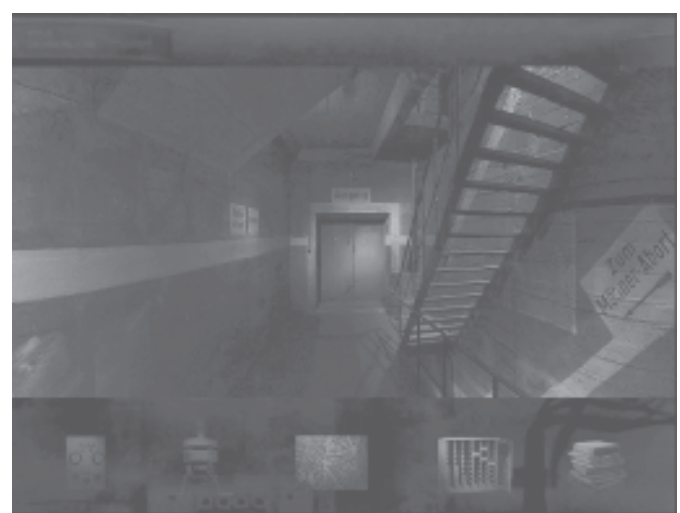

tos de Berlim; o mesmo relativo às imagens fotográficas, tendo contado com o trabalho de retificação de imagens; uma grande pesquisa e criação gráfica com plantas da cidade; uma exploração tanto do subterrâneo quanto de uma visão aérea da cidade; e, sobretudo, uma apresentação não linear e reticular do conteúdo interdisciplinar que envolve arquitetura, sociologia, história, etnologia, arqueologia, geografias física e humana e antropologia. Para tanto, as quase mil fotografias, os 440 planos cartográficos, duas horas de locuções apresentadas como narrativas transversais e o cuidado com as centenas de objetos citados praticamente impuseram a proposta de tratamento interdisciplinar e reorganizaram, num contexto sígnico cronotópico, a idéia de que há uma existência paralela de temporalidades que só pode ser percebida se olharmos para ela a partir de paradigmas espaciais, igualmente paralelos. ${ }^{127} \mathrm{~A}$ imersão nos subterrâneos explora esta idéia de concomitância, tanto por meio das opções em $360^{\circ}$, quanto pela existência da mescla de objetos de várias épocas espalhados pelos labirintos subterrâneos. $\mathrm{Na}$ navegação, encontramos requintes conceituais interessantes, tal como as passagens internas representadas pelas portas, algumas abertas e outras fechadas. Algumas portas abertas oferecem passagem e algumas fechadas não, e vice-versa. Isto não é por acaso, pois cada porta e/ou passagem está associada a temas compatíveis com a região abordada. Isto é equivalente a afirmar que a navegação nos subterrâneos muda os eventos a partir da superfície, bem como a navegação na superfície transforma os eventos no subterrâneo. Outra opção conseqüente está na falta de informações "precisas" sobre a navegação, já que as indicações de espacialidade exploram signos como "saída", 
"entrada", "espaço das comunicações", "comunicação interna" etc., que indicam caminhos, mas não determinam opções interpretativas.


Temos aqui uma outra grande característica das enormes distâncias existentes entre a escrita metodológico-científica e a utilização hipermidiática, considerando que neste universo somente o caminho do uso da tecnologia digital possibilita o encontro entre a relativa "objetividade" da interpretação documental e os rigores teóricos característicos de todo conhecimento científico. Potsdamer Platz é uma obra que aponta à possibilidade de exploração dos ambientes tridimensionais como conceitos texturizados, que, graças a sua texturização, demonstram as possibilidades sígnico-funcionais que relacionam as características de cada objeto com o contexto teórico. Por exemplo, a alavanca motora da sirene do subterrâneo, que ativa e desativa passagens temporal-espaciais, ou motores de ventilação que alargam os critérios de interação. Bauen im Licht já havia demonstrado estas possibilidades de integrar um conjunto de funcionalidades das ferramentas e das estruturas de navegação com as opções de áudio. ${ }^{128}$

Faz parte das opções icônicas, a sirene de alarmes que indica um motor temporal. Há a opção de trabalhar com o aumento da pressão temporal e a condição de explorar o espaço. Os subterrâneos sempre contiveram uma noção de tempo que resistiu à abordagem dos poderes estabelecidos na superfície, tanto em suas orientações políticas quanto em seus conceitos de planejamento urbano. Este jogo de temporalidades é analisado também pela relação entre as cartografias que mesclam as imagens de superfície com as imagens subterrâneas.

As superfícies em cartografia e visão aérea são a opção de navegação que engloba desde os labirintos subterrâneos até visões horizônticas de Berlim. Estão representadas aqui todas as capacidades de interação desta obra, tendo o contexto espacial como um roteiro vivo de acesso às 
regionalidades. Os pontos determinantes variam de época para época, mas em grandes traços existem potencialidades localizadas à espera da interação. Os procedimentos de interatividade, quando remetidos às visões aéreas, nos oferecem uma condição de navegação sem precedentes, pois, estando em evidência as imagens sobre os terrenos como agentes da interação, temos um olhar que é preenchido por toda área de Potsdamer Platz. Isto é proporcional a termos uma visão geral de um texto e podermos navegar em seus fragmentos. Nosso olhar perpassa de uma região para outra, bem como as temporalidades podem ser escolhidas de forma arbitrária e especulativa. Os mapas expressam a estrutura analítica das associações em parte entre conceitos, em parte entre sonoridades e textos associados a cada ponto escolhido por nós. Esta estrutura cronotópica age no sentido de impedir que os fragmentos se organizem de maneira lógica, como pressuposto de apresentar este mundo em si, pois as relações estão, ao mesmo tempo, em evidência e sobrepostas em camadas temporais. As camadas aqui são também o resultado da ação de sujeitos históricos, que evidentemente não podem mais ser resgatados, mas podem ser organizados em horizontes significantes que se realinhem conforme nosso processo de colagem. Ou seja, o lugar no qual podemos inserir nossa subjetividade navegante depende, reciprocamente, de todo processo de construção do ambiente digital realizado pela equipe de pesquisadores. Jamais teríamos a possibilidade de podermos experimentar ações interativas com teorias da reordenação urbana, se não fosse o trabalho de composição categórica das premissas teóricas que orientaram a produção desta obra digital.

Apesar dos ambientes estarem dispostos em ordem cronológica, é graças às interações unidirecionais que a tempora- lidade se subverte, assim como é graças à sobredisposição das regiões abordadas nos mapas aéreos e cartográficos que a temporalidade tenta se afirmar como diacrônica. Subversão e tentativas de interreferencialidades presentificam as grandes possibilidades de exploração teóricoconceitual na construção de um entorno.

No entanto, não podemos nos enganar com a idéia de que somente a utilização de um determinado recurso possa garantir um nível $x$ de interatividade, pois as qualidades das relações entre programação de autoria e manifestações hipermidiáticas são inúmeras e dependem muito mais das diversidades de suas virtualidades do que propriamente dos quesitos que orientam sua interatividade.

Nesta categoria que nomeamos de investigação analítica em versão hipermidiática, temos identificados os principais caminhos de nossa problematização da relação entre mídia digital e investigação científica. Em primeiro lugar, a construção do entorno e sua complexidade, envolvida e totalmente direcionada pelas opções teóricas das referências temáticas. Em segundo lugar, a produção e a manipulação das imagens bem como a citação da iconografia documental só puderam ser trabalhadas a partir da relação entre o entorno e as opções teóricas. Como pudemos ver, isso ocorreu nos três trabalhos analisados (neste item), mesmo considerando a grande diversidade de objetivos e características de cada uma das obras digitais, bem como a diversidade de potencialidades produtivas entre Brasil e Alemanha. Em terceiro lugar, temos o importante trabalho com o áudio, no qual quase todas as categorias tridimensionais estão implicadas. As obras apresentam locuções, efeitos de transição, rotatividade sígnica em texturas musicais e cacos. 


\section{NOTAS}

1) Ver os trabalhos de Burke, Peter. A social history of knowledge. From Gutenberg to Diderot. Oxford: Polity Press \& Blackwell Publishers, 2001; Latour, Bruno. Ciência em ação. São Paulo: Ed. Unesp, 2000; Vovelle, Michel (org.). O homem do lluminismo. Lisboa: Presença, 1999; ou ainda Rossi, Paolo. O nascimento da ciência moderna na Europa. Bauru: Edusc, 2001.

2) O conceito de matriz verbal está fundamentado na obra de Lúcia Santaella, Matrizes da linguagem e pensamento. Sonora Verbal Visual. São Paulo: lluminuras, 2001. As questões que envolvem a historicidade da predominância da matriz verbal no meio acadêmico podem ser encontradas nas seguintes obras: Ong, Walter. Orality and literacy. The technologizing of the Word. Methuen \& Co. Londres. 1982; Chartier, Roger; Cavallo, Guglielmo. Histoire de la lecture dans le monde occidental. Paris: Éditions Laterza et Éditions du Seuil, 1999; Rivière, JeanLoup (org.) Oral/escrito argumentação. Lisboa: Imprensa Nacional - Casa da Moeda - Einaudi, 1990; Bowman, Alan K; Woolf, Greg (orgs.) Cultura escrita e poder. Cambridge, Cambridge University Press, 1997; Eisenstein, Elisabeth L. A revolução da cultura impressa. São Paulo: Ática, 1998; Olson, David R.; Torrance, Nancy (orgs.) Literacy and orality. Cambridge, Cambridge University Press, 1995. Manguel, Alberto. Uma história da leitura. São Paulo: Cia. das Letras, 1997. Olson, David. O mundo no papel. São Paulo: Ática, 1998.

3) Ver Chartier, Roger. Las revoluviones de la cultura escrita. Barcelona: Gedisa, 2001; Heller, Agnes. O homem do renascimento. Lisboa: Presença, 1994; Kuhn, Thomas. A tensão essencial. Lisboa: Edições 70, 1989.

4) Esta concepção pode ser encontrada em inúmeros trabalhos de investigação filosófica: a abordagem semiótica com a concepção de linguagem híbrida de Lucia Santaella, in: Matrizes da linguagem, op. cit.; a concepção de jogos de linguagem de Ludwig Wittgenstein, in: Investigações Filosóficas. Lisboa: Calouste Gulbenkian; os trabalhos de Roland Barthes, tais como O grão da voz. São Paulo: Brasiliense, 1989; Essais critiques. Paris: Seuil, 1964; de Jacques Derrida. Gramatologia. São Paulo: Perspectiva, 1988; ou a abordagem hermenêutica de Hans Georg Gadamer. Wahrheit und methode, Tübingen, J. C. B. Mohr, 1975/1988. 2v. apenas para citar algumas abordagens dentre as quais adotamos.

5) Ver Summers, David. The Judgment of Sense. Cambridge: Cambridge University Press, 1993; Eco, Umberto. Kant e o ornitorrinco. Rio de Janeiro: Record, 1998. Tradução de Ana Thereza Vieira.

6) Esta questão já estava posta em clássicos da década de 50 como Eby, Frederick. The development of modern education. Londres: Prentice-Hall, Inc. 1954; e Bernal, John. Science in history. Londres: C. A. Watts \& CO. Ltd., 1954; ou mais explicitamente abordada em trabalhos como
Jones Caroline A.; Galison, Peter (editors). Picturing science. Producing Art. Londres, Nova York: 2000; e Matos, Cauê (org.) Ciência e Arte. São Paulo: Terceira Margem, 2003. Turney, J. Frankenstein's footsteps. Science, genetics and popular culture. New Haven e Londres: Yale University Press, 1998. Danto, Arthur. Philosophinzing art. Los Angeles: University Califórnia Press, 2000.

7) Considero fundamental o aprofundamento destas abordagens por meio de uma pesquisa que promova a discussão interdisciplinar dos conceitos de autoria, estética e processo de criação.

8) Sui generis, neste sentido, é a obra Wahrheit und methode (op. cit.) do filósofo Hans Georg Gadamer, pois nos oferece a historicidade dos momentos em que a filosofia abandona, em prol de uma lógica da palavra escrita, as noções do pensar presentes no sensu communis e na arte, associando-os às "irracionalidades" do pensamento religioso.

9) Ainda neste início de século XXI, são exigidos o cumprimento de créditos em cursos, a participação em encontros científicos, a contagem de créditos em publicações e, por fim, o desenvolvimento do trabalho escrito que, em média, deve conter cerca de (no mínimo) uma centena de páginas para mestrado e 250 páginas para doutoramento. Apesar destes limites de páginas não estarem expressos em nenhum manual, sabe-se, como que, consuetudinariamente, estas são dimensões de escrita plausíveis para ambas categorias da produção científica em nível stricto sensu. No interior desta trajetória institucional, temos dois momentos clássicos: a qualificação e a defesa. Os critérios de avaliação na qualificação, mais ou menos padronizados, devem garantir a boa continuidade da pesquisa como escrita, bem como a boa qualidade da redação final. A defesa é pública e ocorre de forma oral, momento em que o candidato basicamente deve apresentar suas justificativas perante a argüição dos membros da banca examinadora. Após a defesa, os trabalhos seguem para o Banco de Teses da Universidade, onde a grande maioria permanecerá sem virar publicação, apesar de ter recebido o aval da comunidade científica.

10) Ver Kuhn, Thomas. A estrutura das revoluções científicas. São Paulo: Perspectiva, 1989; Serres, Michel (org.). Élements d'Histoire des Sciences. Paris: Bordas, 1989.

11) A problemática da produção do pensamento científico em equipes, contando com a utilização de recursos digitais, está apenas introduzida neste artigo. No entanto, temos que aprofundar especificamente este tema num outro momento, dada a complexidade das questões que ele reclama. Uma excelente leitura sobre estes novos desafios podemos encontrar em Costa, Rogério da. A cultura digital. São Paulo: Publifolha, 2002.

12) Esta classificação é de fulcral importância para nos- 
sas abordagens. Aqui ela está simplesmente anunciada, pois é necessário alertar o leitor que a taxionomia proposta neste artigo situa-se, em nível analítico, num patamar teórico-metodológicoe técnico-metodológico.

13) Vide os dois últimos capítulos de Santaella, Lúcia. Matrizes. . ., op. cit.

14) Este tema já estava indicado em Schulmeister, Rolf. Grundlagen hipermedialer lernsysteme. Theorie, didaktik und design. Bonn: Addison-Wesley, 1997.

15) In: Foucault, Michel. Les mots et les choses. Paris: Gallimard, 1966.

16) Vide os dois últimos capítulos de Santaella, Lúcia. Matrizes. .. op. cit.; e ainda Hoffman, Donald. Visual Intelligence. Nova York: W. W. Norton \& Company Ltd.; 1998.

17) Ver Bairon, Sérgio; Petry Luis Carlos. Hipermídia, psicanálise e história da cultura. São Paulo/Caxias do Sul: Educs \& Ed. Mackenzie, 2000

18) Neste sentido, seria interessante uma leitura cuidadosa de livros como Morin, Edgard. Le cinema ou l'homme imaginaire. Paris: Éditions de Minuit, 1956; e Galimberti, Umberto. Psiche e techne. Milano: Feltrinelli Editore, 2000; ou Moles, Abrahan. Arte e computador: Porto, Afrontamento, 1990.

19) Esta classificação foi construída a partir da leitura do capítulo "Palavra e imagem" presente no livro Santaella, Lúcia; Nöth, Winfried. Imagem. Cognição, semiótica, mídia. São Paulo: lluminuras, 1998.

20) Aprofundamos esta questão em Bairon, Sérgio; Petry Luis Carlos. Hipermídia, psicanálise e história da cultura, op. cit.

21) Ver Bairon, Sérgio. A rede e o jogo in: Casi nada. Barcelona, Revista digital (disponível em <http://www. casinada. es>).

22) Ver Païne, Dominique. As ruínas. Porto: Cinemateca Portuguesa, 2001; Wolin, Richard. Labirintos. Lisboa: Instituto Piaget, 1999; Matos, Olgária. Vestígios. São Paulo: Palas-Athena, 1998.

23) Aqui temos realmente tudo pela frente, mas seria frutífera uma pesquisa que partisse da leitura de obras como Aguila, Jesus. Le domaine musical. Pierre Boulez et vingt ans de création contemporaine. Paris: Fayard, 1992; Nattiez, Jean-Jacques. Music and discourse: toward a semiology of music. Princeton: Princeton University Press, 1990. Chion, Michel. El sonido. Barcelona: Paidós, 2001.

24) Ver Bairon, Sérgio; Petry Luis Carlos. Hipermídia, psicanálise e história da cultura, op. cit.

25) A relação entre programação e criação é um tema central no interior destes novos desafios. Procurei apontar seus fundamentos em 'A rede e o jogo', in: Casi nada. Barcelona. Revista digital (disponível em <http://www. casinada. com>).
26) Textura musical é como resolvi nomear o trabalho de composição, repleto de montagens e sampleagens, que co-participa dos processos de criação de ambientes digitais hipermidiáticos. A textura musical, portanto, se apresenta como co-partícipe da construção conceitual de um ambiente hipermídiático. Por um lado, tal como a trilha cinematográfica, a textura musical pode ser apreciada separadamente da apresentação do ambiente no qual originalmente habita. Por outro, ao contrário da trilha no cinema, ela se apresenta essencialmente em ambientes interativos hipermidiáticos e deve conviver com os princípios da remixagem e da ressampleagem chegando, até mesmo, a se transformar em outra coisa que não o previsto pelo processo de composição e autoria. Ou seja, as texturas musicais geralmente são produzidas junto das expressividades das montagens imagéticas que se apresentam nas interações.

27) Tenho aprofundado a concepção de randomismo em associação com o conceito de autonomia, fruto de relações possíveis entre dois livros fundamentais: Putnam, Hilary. Realism with a Human Face. Cambridge: Harvard University Press, 1992; e Taylor, Charles. Sources of the self. The making of the modern identity. Cambridge: Harvard University Press, 1990.

28) Entre Alemanha e Brasil, houve inúmeros trabalhos importantes que não foram analisados neste artigo, mas que também trouxeram contribuições às discussões. Dentre eles, destacaria Köll, Udo (coord.) Goethes Reisen. Munique: Universität München - Muldimedia LE Systeme MBH, 1995; Kirmaier, Martin \& Schätzle, Thomas. Der Himmel auf Erden Giovanni Battista Tiepolo in der Residenz zu Würzburg. Munique: Universität München - Muldimedia LE Systeme MBH, 1996 (esta obra ainda contou com a participação do Prof. Dr. Rudolf B. Trabold), na Alemanha; e Machado, Arlindo. Ensaios sobre a contemporaneidade. São Paulo: PUC-SP, 1994, no Brasil.

29) Chaussy, Ulrich. Die Weiâe Rose. Munique: Universität München - Systeme Verlag GmbH, 1995.

30) Chaussy lembra estruturas metodológicas do sistema de montagem no cinema, tema que também está aguardando um grande aprofundamento. Para começar, podemos ler: Manovich, Lev. The Language of New Media. Massachusetts Institute of Technology, 2001; Vertov, Dziga. Kino-eye. Los Angeles: University of California Press, 1984; Eisenstein, S. M. Hacia uma teoría del montaje. Barcelona: Paidós, 2001; Dubois, Philippe. Video, cine, Godard. Buenos Aires: Libros del Roja, 2001; Ribeiro, José. Colá S. John, Oh que sabe! Porto: Afrontamento, 2000; Ades, Dawn. Fotomontage. BarceIona: Gustavo Gili, 2002.

31) A história do cotidiano tem contribuído, teoricamente, com pesquisas que abordam as relações subjetivas entre política, cultura e sociedade. Ver Heller, Agnes. História e cotidiano. Lisboa: Presença, 1988. 
32) A lide com a documentação nesta obra foi profundamente cuidadosa e seguiu as tendências, já estabelecidas, da renovação de documentos, abordagens e objetos exposta em Le Goff, Jacques; Nora, Pierre. Faire de l'histoire: Nouveaux objets. Paris: Gallimard, 1975.

33) Isto ocorria tanto no Brasil quanto na Alemanha. Por parte dos trabalhos acadêmicos, houve vários movimentos de aprendizagem com a produção de conhecimento científico em hipermídia. Neste momento, de 1990 a 1996, estávamos ainda fazendo os primeiros ensaios.

34) As imagens predominantes em Die Weiâe Rose estão na categoria de imagens citadas, mas como vimos, não necessariamente isto limitava o nível de complexidade da pesquisa, o que já não podemos garantir quanto ao resultado hipermidiático desta.

35) Nas abordagens que compõem a história do cotidiano, o homem comum tem muito mais a nos dizer do que o conjunto de documentações que embasam a história político-econômico-social.

36) Bairon, Sérgio (coord.) Cultura e Memória. Itu: Prefeitura de Itu/Faculdade Prudente de Moraes, 1994. Colaboração: Luis Carlos Petry.

37) Cidade localizada no Estado de São Paulo, Brasil, fundada em 1610 e importante marco nos caminhos da proclamação da República brasileira. A cidade, desde a metade do século $\mathrm{XX}$, foi considerada o superlativo da cultura popular brasileira.

38) Foram dois anos de coleta de material em imagens, vídeos e áudios. Momento ainda inaugural da pesquisa que conhecemos como formação de bancos multidimiáticos.

39) Este caminho circular, que perpassa tematicamente várias abordagens, foi estudado, ainda em 1991, por Landow, George; Delany, Paul. Hypermedia and Literary Studies. Cambridge / Londres: MIT Press, 1991.

40) É importante destacar que há uma relação de cumplicidade entre, de um lado, a condição analítica e a utilização de recursos digitais e, de outro, o conhecimento de programação de autoria e as estratégias de formação e utilização dos bancos multimidiáticos.

41) A obra Deutsch, Deutsche, Zeiten / eine chronik apresenta com muita propriedade a tensão entre narrativa linear e construção de ambiente digital não-linear.

42) Bögeholz, Hartwig. Deutsch, Deutsche, Zeiten / eine chronike. Munique: Bielefeld Universität - Systhema Verlag GMBH, 1996.

43) Existem várias temporalidades interferindo nesta criação: o tempo da guerra, o tempo do fim da guerra, o tempo da reconstrução, o tempo da tradição, o tempo da memória e o tempo da opressão. O desafio esteve em criar um ambiente que reunisse todas estas temporalidades numa só opção em $360^{\circ}$.
44) Ver Bairon, Sérgio. "Method, Hermeneutics and Hypermedia", in: Convenit - Selecta - 2 - ISSN - 15176975 - This special printed edition is published by Harvard Low School - Cambridge - 2000. pp. 57-62.

45) Sem dúvida que o alcance do equilíbrio entre o universo de conceitos que abrangem uma obra digital representa um dos desafios mais importantes a ser conquistado.

46) Guelman, Leonardo. Univvvverrsso Gentileza. A gênese do mito contemporâneo. Rio de Janeiro: UFF/Pontuar, 1997.

47) São algumas das obras que norteiam este trabalho: Deleuze, Gilles. A dobra: Leibniz e o Barroco. São Paulo: Papirus, 1988; Derrida, Jacques. Gramatologia. São Paulo: Perspectiva, 1973; Heidegger, Martin. Ser e Tempo. Petrópolis: Vozes, 1993.

48) O lugar é o circo, e o circo é o mundo de Gentileza. Este tipo de lógica já estava posta na obra Heim, Michael. Virtual Realism. Nova York/Oxford: Oxford University Press. 1998. Sobretudo no momento nos momentos em que Michael Heim traduz Bewandtniszusammenhang por context of relationships.

49) A obra digital inteira é um grande jogo com o mundo do Gentileza e, por se tratar justamente de seu universo as opções interativas só poderiam ser singelas. Acerto de Guelman.

50) Tal como apresenta Marcus Bastos (in: Palavra e Imagem na Mídia. Um estudo intercultural Brasil-Alemanha) em seu texto, é bem verdade que em meio aos trabalhos de criação artística o abandono de um nível objetivo metodológico da escrita não é mais novidade. Mas nada disso chega sequer perto dos trabalhos acadêmicos em strictu senso.

51) O sentido da emulação aponta à criação de um ambiente que não se proponha simular algo ou alguma coisa, mas sim que se apresente como inaugural de um mundo interativo. Ver: Norman, Donald. The invisible Computer. Nova York/Oxford: Oxford University Press. 1998.

52) Ver: Braudel, Fernand. "Histoire et sciences sociales: la longue durée", Annales, 17, 1958.

53) Engelbert, Arthur (org.). Bauen im licht-das glashaus von Bruno Taut. Berlin: Werkbund-Archiv Berlin/ Potsdam Universität, 1996.

54) Idem, interação a partir da opção triângulo.

55) Associação que arquitetos alemães, artistas e críticos fundaram em Berlim em dezembro de 1918 sob a coordenação de Bruno Taut, dissolvida em 30 de maio de 1921. O corpo de membros incluía os arquitetos Otto Bartning, Walter Gropius, Paul Mebes, Erich Mendelsohn, Hans Poelzig, Paul Schmitthenner, Max Taut and Heinrich Tessenow; os pintores César Klein, Erich Heckel, Käthe 
Kollwitz, Ludwig Meidner, Max Pechstein, Karl SchmidtRottluff e Lyonel Feininger; os escultores Rudolph Belling, Oswald Herzog e Gerhard Marcks.

56) Ver Sharp, Dennis. The Illustrated Encyclopedia of Architects and Architecture. Nova York: Quatro Publishing, 1991.

57) Paralelamente à lembrança de Taut, é importante reforçar esta característica pragmática, pois tenho defendido há muito tempo a necessidade premente da existência da produção de obras digitais.

58) Ver Bairon, Sérgio. Interdisciplinaridade. Educação, história da cultura e hipermídia. São Paulo: Futura, 2002; Le Goff, Jacques (org.). Memória e história. Lisboa: Enciclopédia Einaudi, 1984.

59) Aqui temos o centro da argumentação deste artigo: criações analítico-sígnicas hipermidiáticas revelam expressividades que nenhum sistema de escrita metodológica seria capaz de nos oferecer.

60) A qualidade da estrutura tridimensional de Bauen im licht está, portanto, garantida graças à existência de um conjunto de fatores que atuam conjuntamente: texturas, colagens e cacos sonoros.

61) No interior de uma hipermídia, as imagens podem ser entendidas como hipoícones que se estruturam em diagramas e metáforas. Ver: Santaella, Lucia: Nöth, Winfried. Imagem, op. cit., p. 62.

62) Schullmeister já havia alertado quando à complexidade da relação entre programação e criação (in: Schulmeister, Rolf. Grundlagen hipermedialer lernsysteme. Theorie, didaktik und design, op. cit.); no entanto, esta característica nunca havia sido aprofundada a partir de uma prática hipermídiática.

63) Esta abordagem foi percebida por Lúcia Santaella em seu livro Matrizes da linguagem e pensamento (op. cit.), sobretudo nos dois últimos capítulos. Noutro patamar, advindo de seus estudos sobre poética e hipertexto, encontramos Joyce, M. Other Mind-edness. The emergence of network culture. University Michigan, 2000.

64) Esta é outra questão central que tem merecido uma grande atenção em minhas pesquisas. Para tanto, tenho buscado ler e reler as relações entre historicidade e estética. Para uma introdução básica, indicaria obras introdutórias como Adorno, Theodor. Asthetische Theorie. Frankfurt: Suhrkamp-Verlag Frankfurt am Main, 1970; o clássico Bayer, Raymond. Histoire de l'Esthétique. Paris: Armand Colin, 1961; ou ainda Bozal, Valeriano (org.) Historia de las ideas estéticas y de las teorías artísticas contemporáneas. Madrid: Visor, 1999. 2v.; e Franzini, Elio. La estética del siglo XVIII. Madrid: Visor, 1999; Pita, António P. A Experiência estética como experiência do mundo. Porto: Campo das Letras, 1999; ou ainda textos que se aproximam mais das questões semióticas, psicanalíticas e tecnológicas, como Costa, Mário. L'estetica dei media. Roma: Editoria \& Comunicazione srl, 1999; Menezes, Philadelpho. A crise do passado. São Paulo: Experimento, 2001; Santaella, Lúcia. Estética de Platão a Peirce. São Paulo: Experimento, 1994; Krauss, Rosalind. The Picasso papers. Nova York: Farrar, Straus and Giroux, 1998; Foster, Hal. The Return of the real. Cambridge/Massachusetts: MIT Press, 1999; ou, ainda, em linha de abordagens mais interdisciplinares, como Gadamer, Hans Georg. Estética e hermenêutica. Madrid: Tecnos, 1996.

65) Esta relação remete à associação possível entre os processos criativos na ciência e na arte. Temos aqui outra pesquisa a ser desenvolvida, que nos possibilite ensaiar o encontro entre a idéia de conceitualização na arte quanto na ciência. De um lado temos, por exemplo, Krauss, Rosalind. The optical unconscious. Cambridge/ Massachusetts: MIT Press, 1993; __. The originality of the Avant-Garde and Other Modernist Myths. Cambridge/Massachusetts: MIT Press, 1985; Foster, Hal. Compulsive Beauty. Cambridge/Massachusetts: MIT Press, 1997; e, de outro, um encontro com Besançon, Alain. L'image interdite. Paris: Librairie Arthème Fayard, 1994; e Derrida, Jacques. La vérité en peinture. Paris: Flammarion, 1978; Cage, John. Colour and Meaning. Art, science and symbolism. Londres: Thames \& Hudson, 2000.

66) Ver Schönberg, Arnold. Armonia. Madrid: Real Musica, 1974.

67) Goifman, Kiko. Valetes em slow motion. Campinas: Editora Unicamp, 1998.

68) Importa registrar que todas estas questões estão relacionadas com vários autores e conceitos que foram trabalhados nesta obra. Dentre eles, Theodor Adorno, Philippe Ariés, Gilles Deleuze, Henri Bergson, Michel Foucault e Lúcia Santaella. Com respeito a Lúcia Santaella, o autor já havia tido contato com seu artigo (expandido e publicado como livro no ano 2001, op. cit. .) "Três matrizes da linguagem e pensamento", Revista Forum, BHZ-Vídeo, n. 1, Belo Horizonte, 1992.

69) O grande trabalho anterior de coleta e sistematização de bancos multimidiáticos é sempre decisivo para a conseqüente qualidade analítica das interpretações. Ver Bairon, Sérgio; Petry, Luis Carlos. Hipermídia, psicanálise. . ., op. cit.

70) Tradições de narrativas reticulares já haviam sido profundamente desenvolvidas em vídeo, ver: Dubois, Philippe. Video, cine, Godard, op. cit., ou Machado, Arlindo. Máquina e Imaginário. $O$ desafio das poéticas tecnológicas. São Paulo: Edusp, 1993.

71) Aqui vejo a expressividade hipermidiática da obra Foucault, Michel. Microfísica do poder. Rio de Janeiro: Graal, 1984. Obra referenciada inúmeras vezes pelos autores.

72) Transições, passagens e perpasses são eventos fun- 
damentais em uma obra hipermidiática. Não só porque apresentam uma ligação temática interna à obra, como também porque pressupõem uma mudança de estado de consciência. Tal questão está analisada, de forma introdutória, em obras como Bolter, David. Writing space. Nova Jersey: Lawrence Erlbaum Associates, 1991; ou em Joyce, Michel. Of two minds. Michigan: University of Michigan Press, 1995.

73) A relação entre ambiente e uso é fundamental, sobretudo quando estivermos trabalhando com um conceito de habitação. Ver Hillis, Ken. Digital sensations. Minneapolis/ Londres: University of Minnesota Press, 1999.

74) A conjunção de referências teóricas com o ambiente está aqui contemplada. É neste sentido que um entorno pode ser tanto produzido quanto avaliado segundo suas implicações construtivo-conceituais. Tenho insistido não simplesmente no abandono de várias das exigências metodológicas ainda hoje existentes, mas sim na necessidade de suas atualizações.

75) Como as ocorrências na obra Valetes, a relação entre as estruturas de poder e as leis em vigência depende de uma espécie de reinterpretação hermenêutico-jurídica que só pode se revelar por meio de citações do cotidiano.

76) As ocorrências nas paredes gastas aparecem como janelas. Janelas sem fundo. Como criar este conceito no escrita impressa característica da metodologia científica contemporânea?

\section{7) Catálogo da Bienal de São Paulo - 1996.}

78) A abordagem desta relação remete para mais um tema que aguarda aprofundamento: a possibilidade do desenvolvimento de um estilo (se é que o conceito é este) de reflexão e criação hipermidiática, assim como no interior de um texto científico desenvolvemos uma maneira própria de construirmos logicamente nossas argumentações.

79) Já podemos dizer que ocorre com relativa freqüência nos dias de hoje o fato de acrescentarmos à dissertação ou tese um CD-ROM ou uma criação em site. Deste momento em diante, temos que conquistar a possibilidade de investigarmos e apresentarmos nossas pesquisas já em hipermídia.

80) Várias destas temáticas já foram abordadas em: Bell, David: Kennedy, Barbara. The cybercultures reader. Londres: Routledge, 2000; Hansen, Mark. Embodying technesis. Technology beyond writing. Michigan: University of Michigan Press, 2000; Vouillamoz, Núria. Literatura e hipermedia. Barcelona: Paidós, 2000; Aronowitz, Stanley; Martinsons, Barbara; Menser, Michael (eds.) Technoscience and cyberculture. Nova York/Londres: Routledge, 1996; Darley, Andrew. Visual digital culture. Nova York/Londres: Routledge, 2000. No entanto, sempre ficamos aguardando que os departamentos das universidades mundo afora comecem a promover a produção de defesas em estruturas digitais e, daí, surja uma metodologia de avaliação.

81) Teríamos um grande número de autores para pesquisar neste sentido. Por uma questão de espaço, apenas citarei a lista de autores que considero fundamental para tal empreitada: Mikail Bakhtine, Agnes Heller, Hans Georg Gadamer, Alexandre Koyré, François Hartog, Michel de Certeau, Jacques Derrida, Gustav R. Hocke, Luiz Costa Lima, Roger Chartier, Lúcia Santaella, Jacques Le Goff, Elizabeth L. Eisenstein, Umberto Eco, Roland Barthes, Roy Pascal, Michel Joyce, George Landow, David Bolter e Rolf Schullmeister. Este trabalho está sendo feito e devo publicá-lo em breve.

82) De formas diversas mas complementares, podemos encontrar estas questões em: Piault, Marc Henri. Anthropologie et cinéma. Paris: Editions NATHAN/HER, 2000; Cage, John. Colour and Meaning. Art, science and symbolism, op. cit.; Morin, Edgard (org.). Relier les Connaissances. Paris: Éditions du Seuil, 1999; Taylor, Charles. Philosophical arguments. Cambridge: Harvard University Press, 1995; e Gadamer, Hans Georg. Elogio de la teoría. Barcelona: Peninsula/ldeas, 1993.

83) Foi em parte o que tentamos fazer na obra Hipermídia, psicanálise. ... op. cit., ao optarmos pela criação de um ambiente tridimensional que nos recebe como visitante antes mesmo de concluirmos do que se trata.

84) É para o que nos alerta Thomas Kuhn em seu livro $A$ tensão essencial (op. cit.), ao afirmar que toda teoria científica é movediça na estabilidade e inefável no acabamento.

85) Tenho trabalhado intensamente a partir do conceito de margem. Algumas leituras e consultas têm sido fundamentais: Putnam, Hilary. The many faces of realism. Nova York: Open Court Publishing Company, 1990; Chartier, Roger. escribir las práticas. Buenos Aires: Manantial SRL, 1996; Certeau, Michel. L'invention du quotidien. 1. Arts de faire. Paris: Gallimard, 1990; Santarcangeli, Paolo. II libro dei labirinti. Storia di um mito e di um simbolo. Roma: Frassinelli, 1984; Gitelman, Lisa. Scripts, grooves, and writing machines. California: Stanford University Press, 1999; Breton-Gravereau, Simone; Thibault, Danièle. L'aventure des écritures. Matières et formes. Paris: Bibliothèque de France, 1998; Certeau, Michel de. A escrita da história. Rio de Janeiro: Forense Universitária, 1982.

86) John, Franz. Interzone. Berlin: Verlag Galerie Scüppenhauer, 2000.

87) Desde sua origem este trabalho já estava sendo pensado como um ambiente imersivo.

88) A concepção da utilização de uma cartografia como guia, já fora anunciada 4 anos antes deste trabalho por Schullmeister, Rolf. op. cit.

89) Ver Bairon, Sérgio. 'A rede e o jogo'..., op. cit.

90) Ver Bairon, Sérgio; Petry, Luis Carlos. Hipermídia, 
psicanálise..., op. cit.

91) Consultar a opção Zone $X$ da obra.

92) O que há muito já vem acontecendo em linhas de abordagem como a História das Mentalidades, a Antropologia Visual oua Literatura comparada, somente para citar algumas.

93) Destacaria Bellour, Raymond; Duguet, Anne Marie. "Vidéo", Communications n. 48, Paris: Seuil, 1988; Preikschat, Wolfgang. Video. Die poesie der neuen medien. Bale: Beltz, 1987; Hall, Doug; Fiffer, Sally Jo. Illuminating Video. An essential guide to video art. Nova York: Aperture/BAVC, 1990; Duguet, Anne Marie. Video, la mémoire au poing. Paris: Hachette, 1981; Belloir, Dominique. "Vidéo art exploration", Cahiers du cinéma. Paris: octobre, 1981; Bloch, Dany. L'art Vidéo. Paris: Limages 2/Alin Avila, 1983; Popper, Frank. L'art à l'âge électronique. Paris: Hazan, 1993; Perrée, Rob. Into video art. The characteristics of a medium. Amsterdan: Com Rumore/ldea Books, 1998; no Brasil, destacaria Machado, Arlindo. A arte do vídeo. São Paulo: Brasiliense, 1988; Plaza, Julio. Videografia em videotexto. São Paulo: Hucitec, 1986.

94) A modelagem em 3D no interior de um ambiente hipermidiático deve ser encarada como uma estratégia de criação conceitual. Destaque para o trabalho de Luis Carlos Petry em Bairon, Sérgio; Petry, Luis Carlos. Hipermídia, psicanálise..., op. cit.

95) Neste sentido, o trabalho deixa muito a desejar, pois podemos esperar que qualquer modelagem tridimensional do muro deva se preocupar com as fissuras, registros etc., presentes e sobreviventes de um sítio tão repleto de iconicidade.

96) O conceito de anomalia aqui é utilizado tal como o sentido que lhe dá Thomas Kuhn em A estrutura das revoluções..., op. cit.

97) Temos aqui um enorme desafio à noção de documento científico. Ver Heller, Agnes. A philosophy of history in fragments. Oxford: Blackwell Publishers, 1993.

98) As relações feitas por Richard Wolin entre a concepção de labirinto e a obra de Benjamin, Derrida e Heidegger são muito instigantes para pensarmos ambientes imersivos. Ver Wolin, Richard, op. cit.

99) Este princípio está exposto nos cadernos de montagem de imagens manipuladas em Bairon, Sérgio; Petry, Luis Carlos. Hipermídia, psicanálise..., op. cit.

100) Bairon, Sérgio; Petry, Luis Carlos. Hipermídia, psicanálise..., op. cit.

101) As relações realizadas aqui remeteram à topologia lacaniana. Bairon, Sérgio; Petry, Luis Carlos. Hipermídia, psicanálise..., op. cit.

102) Santaella, Lúcia. "Apresentação". In: Bairon, Sérgio; Petry, Luis Carlos. Hipermídia, psicanálise..., op. cit..
103) A ação da parede aciona a frase "Não há possibilidade de banharmo-nos duas vezes no mesmo signo", jogo entre Heráclito e a revisão lacaniana do conceito saussuriano de signo. Para Lacan, a relação significante/ significado (de F. Saussure) transforma-se em significante/significente/significante, e o sentido é fruto sempre movediço de uma rede significante.

104) As dimensões não verbais, que estão presentes em grande parte dos conceitos teóricos de Hipermídia, psicanálise e história da cultura, adquiriram uma condição hipermidiática, graças às possibilidades produtivas da relação entre o tratamento dado aos conceitos no processo criativo e a interlocução com autores, cuja obra já promovia a interdisciplinaridade abordada por nós.

105) No caminho apontado por Michel De Certeau em L'invention du quotidien..., op. cit.

106) Ver Zizek, Slavoj. The ticklish subject. The absent centre of political ontology. Londres-Nova York: Verso, 1999.

107) Ver Lacan, Jacques. Seminário 13. O objeto da psicanálise. Base de dados Luis Carlos Petry.

108) Foucault, Michel. Esto no es una pipa. Barcelona: Anagrama, 1981; Barthes, Roland. O óbvio e o obtuso. Lisboa: Edições 70, 1984; Lacan, Jacques. Seminário 13. O objeto da psicanálise, op. cit.

109) Ainda faz parte de nossos estudos a possibilidade de um tratamento conceitual da trilogia heideggeriana, Umwelt (mundo a nossa volta), Mitwelt (mundo com) e Selbstwelt (mundo próprio - anunciação do Dasein), com um desdobramento teórico-metodológico. Neste sentido, em alguns momentos trataremos de entorno, de mundo com ou de mundo-em-si.

110) Ver Gadamer, Hans Georg. Elogio de la teoría, op. cit.; em oposição ao que se poderia pensar pelo o que foi afirmado até aqui, não pretendo abandonar a proposta que define teoria como um conjunto de conceitos e hipóteses que pretende sustentar a exposição de asserções científicas. Ao contrário, creio que um aprofundamento hipermidiático da linguagem teórico-científica abrirá horizontes, tanto de expressividades quanto de interatividades que a escrita científica do juízo lógico teimou em esquecer.

111) Destacaria, sobretudo, os trabalhos de Rosalind Krauss e de Hal Foster em suas bases psicanalíticas.

112) Ver Kadrey, Richard. From Myst to Riven. Nova York: Hyperion, 1997.

113) A estrutura icônica buscou uma relação hipoicônica com todo o contexto do labirinto. Ou seja, num primeiro momento, há uma relativa similaridade com cada função a que se propõe desempenhar cada opção icônica; num segundo momento, os ícones se apresentam como diagramas, pois expressam uma estrutura vetorial análoga com suas partes; e, num terceiro momento, transformam- 
se em metáfora, já que agem como um signo que traça um paralelismo de um universo, diverso de si, mas presente na obra digital. Concepções formuladas a partir de uma leitura hipotética de Santaella, Lúcia; Nöth, Winfried. Imagem, op. cit., p. 62.

114) Ver Buckhardt, J. Force and freedom: reflections on history. Nova York: J. H. Nichols, 1955.

115) Idem, ibidem.

116) Cito Morin: "Na ciência, a unidade foi sempre hiperabstrata, hiperformalizada, e só pode fazer comunicarem-se as diferentes dimensões do real abolindo essas dimensões, isto é, unidimensionalizando o real". Morin, Edgard. Science avec conscience. Paris: Éditions du Seuil, 1998. p. 64.

117) Um pouco na linha do que Sherry Turkle salienta em Turkle, Sherry (org.). High wired. Michigan: University of Michigan, 1998; mas a obra mais fundamental temos em Santaella, Lúcia. Matrizes..., op. cit.

118) Sistemas de busca podem, concomitantemente, ser o resultado da composição de estruturas analíticas e a possibilidade de recomposições de inter-relações teóricas.

119) Ver plataforma do disco, in: Bairon, Sérgio: Petry, Luis Carlos. Hipermídia, psicanálise..., op. cit.

120) Diz Lacan no Seminário 3: "Esta incógnita na alteridade do Outro é o que caracteriza essencialmente a relação de palavra no nível em que é falada ao outro". Lacan, Jacques. Seminário 3. As Psicoses. Rio de Janeiro: Jorge Zahar, 1992.

121) Dietmar, Arnold. Potsdamer Platz. Berlin: Technischen Universität Berlin / Ekuinteractive, 2002.

122) O desafio de trabalhar com uma gama de imagens fotográficas, à busca de uma construção hipermidiática que perpasse por diversas temporalidades, é o grande

Recebido em agosto de 2004

Aceito para publicação em setembro de 2004 objetivo imersivo desta obra. Uma leitura interessante sobre o conceito de imersão encontramos em: Heim, Michael. Virtual Realism. Nova York: Oxford University Press, 1998; a relação entre os conceitos de tridimensionalidade e imersão ainda deve ser aprofundada, mas podemos encontrar alguns caminhos: Murray, Janet. Hamlet on the Holodeck. The Future of Narrative in Cyberrspace. Cambridge: MIT Press, 1998; Cobb, Jennifer. Cybergrace. Nova York: Crown Publishers, 1999. Davis, Erik. Techgnosis. Nova York: Harmony Books, 1999.

123) Por exemplo, a relação entre uma engrenagem do final do século 19, que movimenta a retomada do Pangermanismo em plena ascensão nazista na década de 30 do século 20 .

124) Ver Bairon, Sérgio; Petry, Luis Carlos. Hipermídia, psicanálise..., op. cit.

125) Como Umwelt, o espaço tridimensional oferece habitação aos objetos do cotidiano transhistórico, transformando o ambiente em Mitwelt.

126) Heller, Agnes. Cotidiano e..., op. cit.; Certeau, Michel De. L'invention..., op. cit.

127) As quatro temporalidades diversas desta obra digital coexistem no interior das possibilidades criadas e produzidas com efeitos fotográficos em $360^{\circ}$.

128) Ruídos, vozes, efeitos e pequenas transições fazem do áudio desta obra digital um acerto imersivo. O áudio contém uma dimensão tridimensional assim como as estruturas imagéticas, ou, se preferirmos, a tridimensionalidade de cada evento é alcançada graças às múltliplas auto-referencialidades.

\section{Sérgio Bairon}

Doutor em História Social/USP, professor da Universidade Presbiteriana Mackenzie e da Pontifícia Universidade Católica PUC/SP. Pós-doutorado na PUC/SP e na Freie Universitat Berlin, Alemanha.

E-mail: bairon@attglobal.net 